\title{
أسماء مواليد المصريين المعاصرين: دراسة فى لغويات المعلومات
}

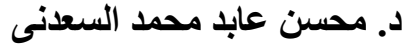

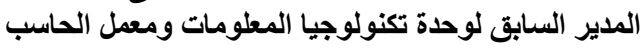

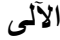

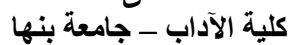 \\ منتب لكلية الآداب والعلوم الإنسانية جامعة قتاة السويس \\ mohsen.aabed@gmail.com
}

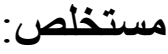

تتناول الدر اسة أسماء مو اليد المصريين المعاصرين من منظور لغويات المعلومات، وتسعى

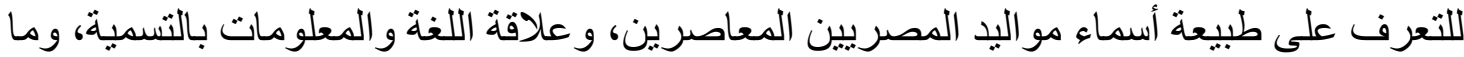
تتضمنه الأسماء وما تقدمه من معلومات مختلفة متضمنة الأسماء الأكثر والأقل شيوعًا وفئًات

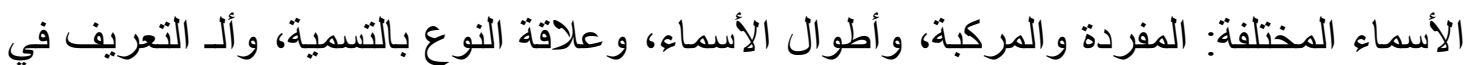

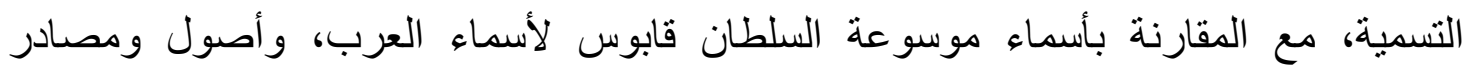
الأسماء، و التصنيفات الموضو عية في التسمية، وجذور الأسماء، والصيغ الصرفية لهاء ولهاء والأسماء

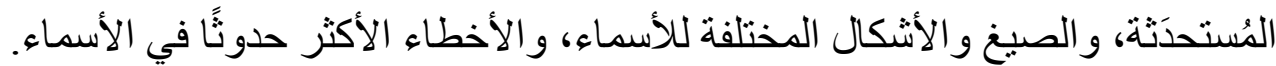

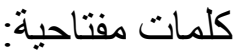

الأسماء المصرية ـ لغويات المعلومات ـ أسماء مو البد المصريين.

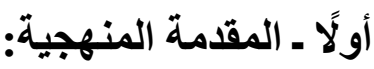

(1) (1) (1)

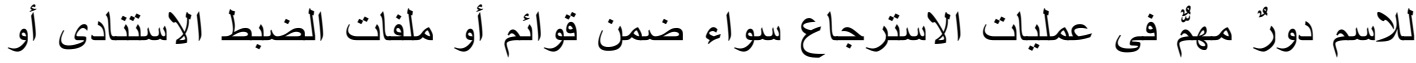

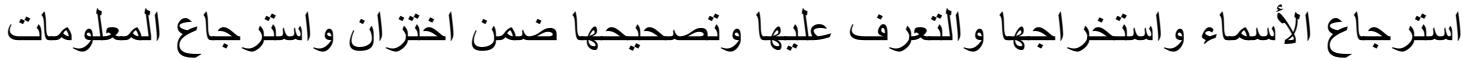
أو التنقيب عنها، لذا فمن الضرورى التعرف على طبيعة الأسماء العربية وخصائصها وصناء وصفاتها ومشكلاتها المختلفة، فدر اسة الأسماء المُستخدَمة خلال فترة ما فى مجتمعِ ما يساعد في اكتمال 
عملية الضبط الاستنادى وفى معرفة شكل الاسم المستعمَل خلال هذه الفترة، وتبيان دولة المؤلف و التحقق من صحة الاسم ونسبته له، كما يساعد فى التعرف على أخطاء التسمية و أخطاء الكتابة التهاء ومعالجة بعض أخطاء تسجيلات الأسماء الناتجة عن أخطاء تسجيل البيانات أو الناتجة عن أخطاء إملائية. وبتطبيق لغويات المعلومات يمكن لهذه المعلومات أن تساعد فى استتتاج الاسم الصحيح

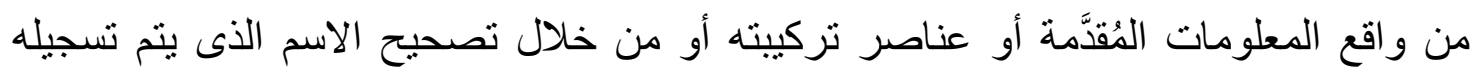

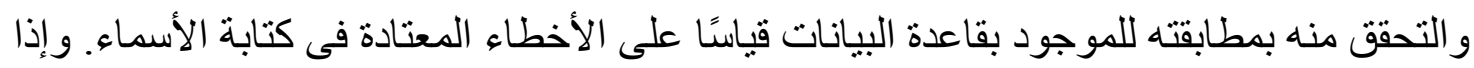

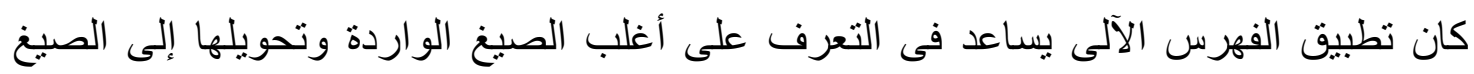
المستخدمة، فإن بعض الحالات قد تخرج عن إطار النظام الآلى؛ لذا فمن الضرورى لـى تناول

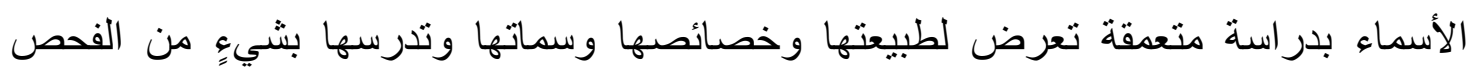

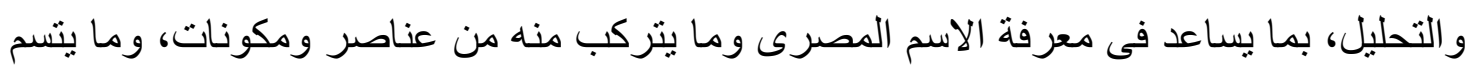

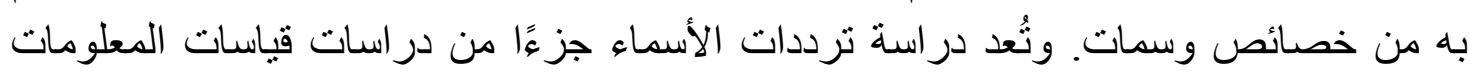

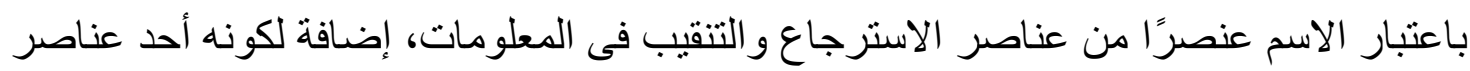
الوصف الببليوجر افى. (Y) (Y) مشكلة الدر اسة:

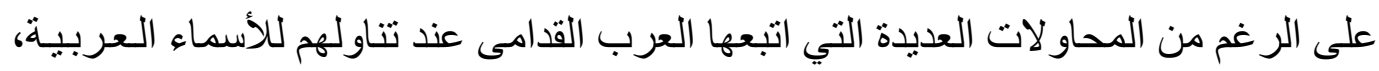

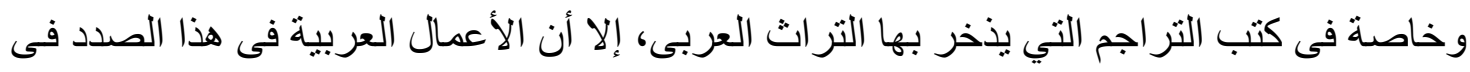
الوقت الحاضر محدودة للغاية(')، و هناك نقص في الدر اسات العلمية الجـادة فى ذلك الكَ المجـال(؟).

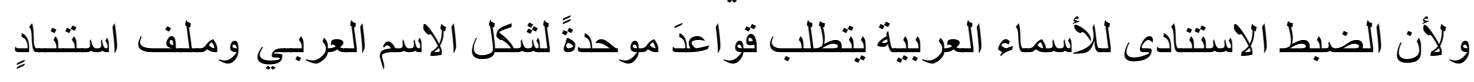

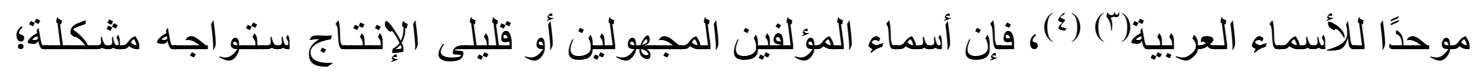

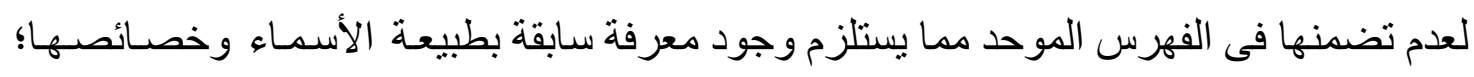

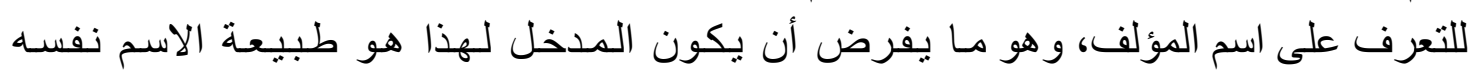
وخصائصه.

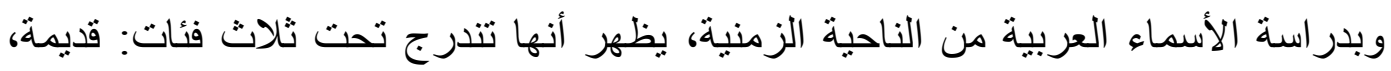

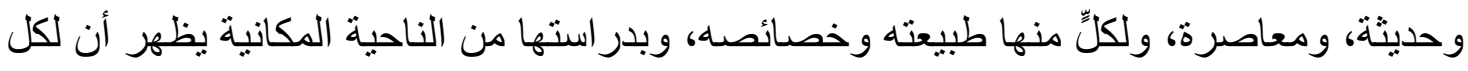

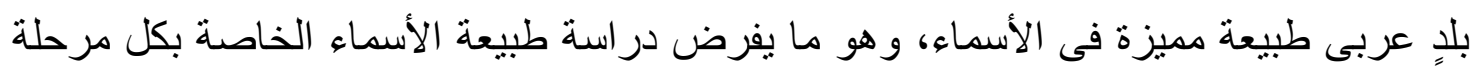
وفى كل بلد؛ للتوصل إلى خصائصها وسماتها المستقلة. و إذا كان استرجاع المعلومات يعتمد على ما سُجل فى قو اعد البيانات، فإن تسجيله خطأ يؤدى

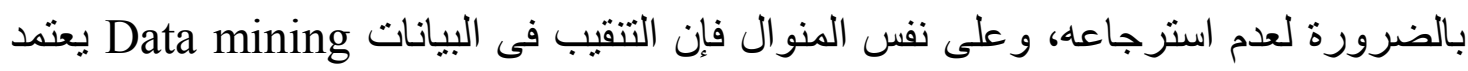

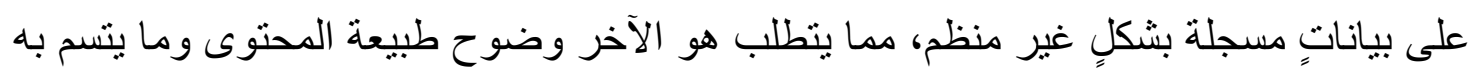
الاسم من خصوصية بتغير الزمان و المكان حتى يكون استخر اجه صحيحًا. 
ويمكن صياغة مشكلة الدر اسة فى السؤ ال الآتى: ما طبيعة أسمـاء المصريين المعاصرة

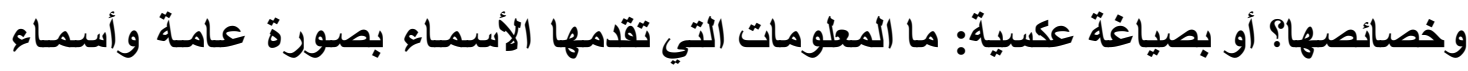

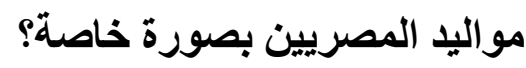

$$
\text { (T) أهمية الدر اسة ومبرر ات اختيار ها: }
$$

تتجه الدر اسة إلى عنو ان كل إنسان، و هو اسمه الذى يرسم صورة مختصرة لحياته كلها. و لا

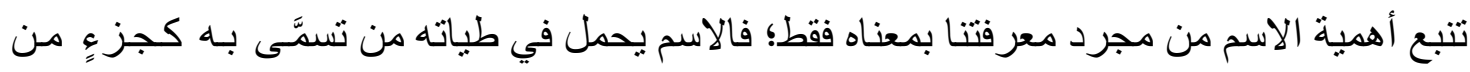

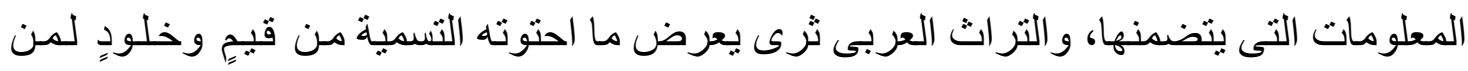

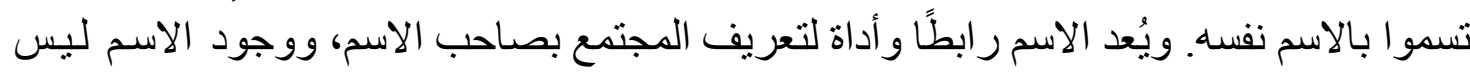
أمرًا عبثيَّا؛ لأن الأفر اد يقو مون بالتسمية بدافع وحافز و غرض معلوماتى، حيث تتباين المعلومـات

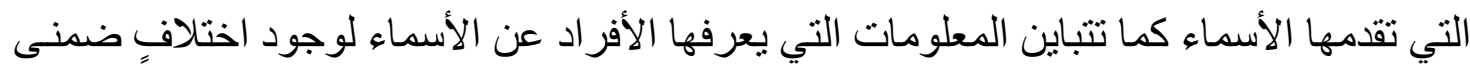
فيما بينهم في نوع ومقدار المعلومات التي ير غبها الإنسان ومقدار معرفته بها؛ و هذه الأخيرة تؤثر

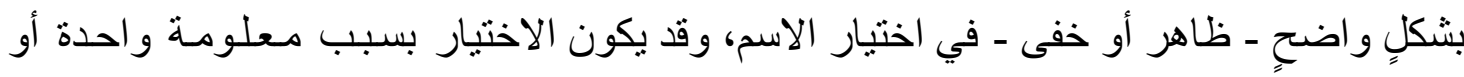

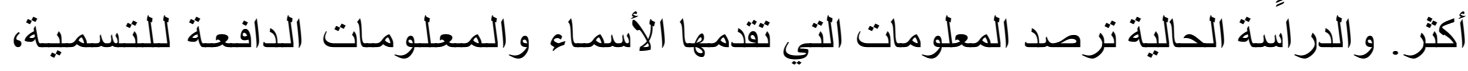
وتعرض لدور وقيمة المعلومات و أثر ها في الأسماء و التسمية؛ من أجل معالجـة مشـاكل الأسمـاء

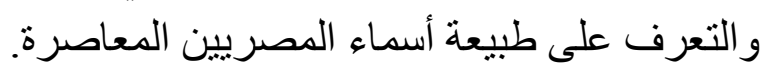

جاء اختيار موضوع الدر اسة؛ لكونه موضو عًا جديدًا لم يُدرَس فى إطار التخصص، ويتمبز

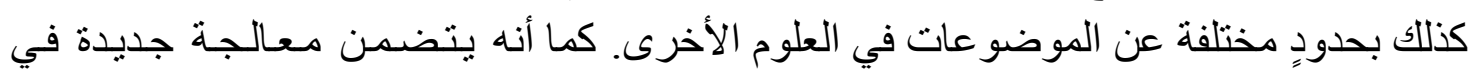

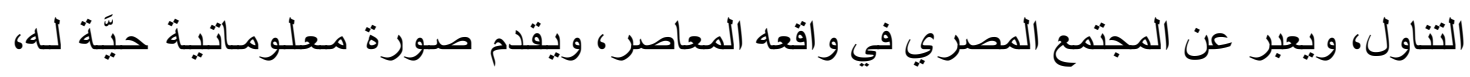

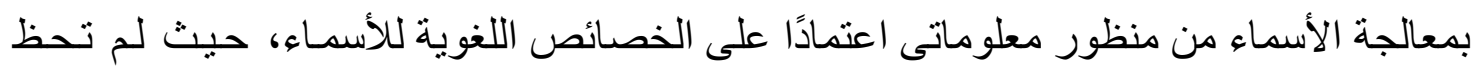

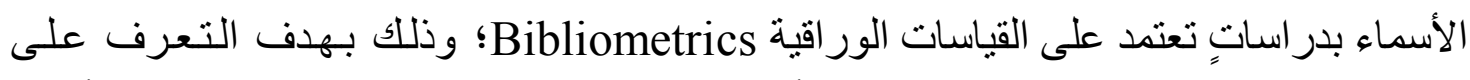

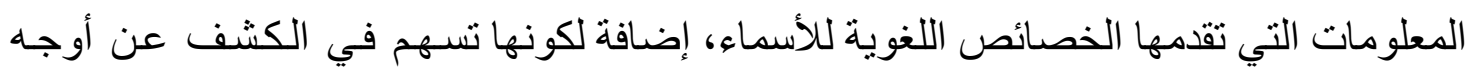

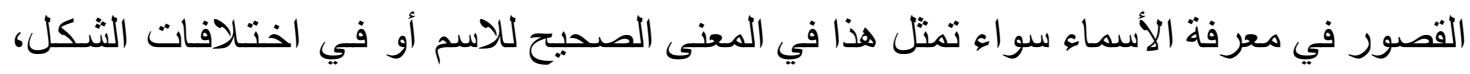

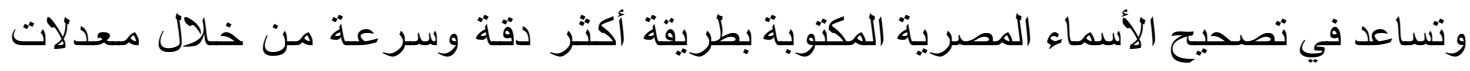
التو اتر للذكور والإناث و الديانة والاسم الأول، إضـافة لبناء برمجيات تساعد على المعالجـة الآلية

للمعلومات.

يضاف إلى ذلك ما شهدته مصر و الدول العربية من طوفانٍ كاسحٍ من الثقافات الأجنبية التى

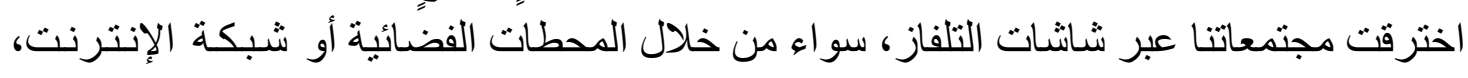

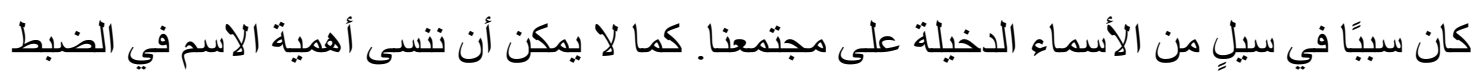

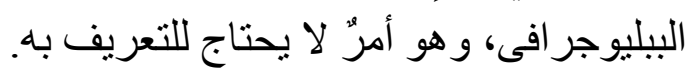

\section{أخيرًا، فإن معرفة طبيعة الأسماء يساعد في إنشاء برامج حاسب؛ لمراجعة وضبط}




\section{الاستشهادات وللتحويل بين طرق وأساليب صياغة الاستشهادات المرجعية المختلفة.}

$$
\text { أهداف الدر اسة وتساؤ لاتها: }
$$

يُعد شيوع نمطٍ أو شكلٍ معين من الأسماء دلالة على نمط من المعلومات والثقافة التى تؤثر

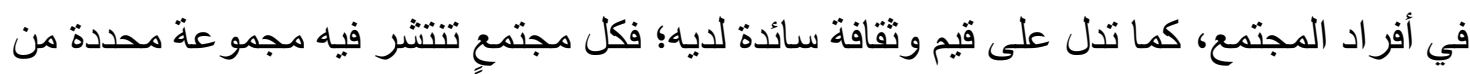

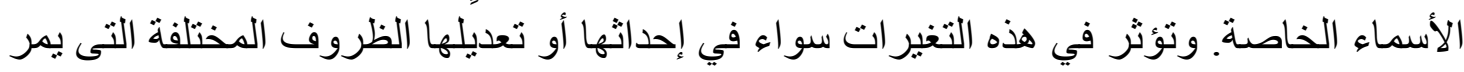
بها المجتمع ويعيشها أفر اده، سواء من الناحية السياسية أو الاقتصادية أو الاجتماعية أو التقافية أو أو الدينية.

وتسعى الدر اسة الحالية لمعرفة المعلومات التي تقدمها الأسماء، و التي هي في نفس الوقت سببًا

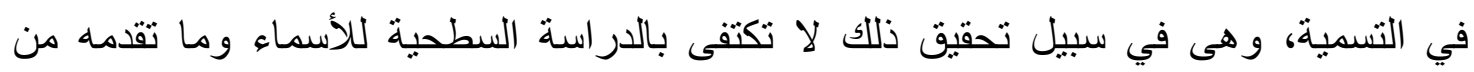

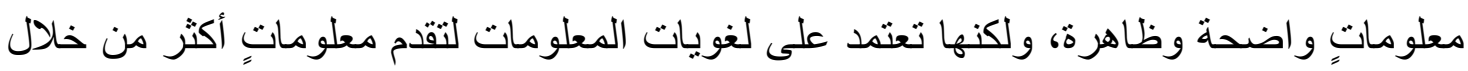

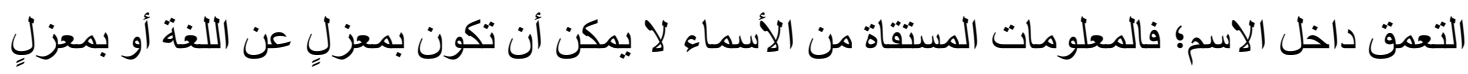

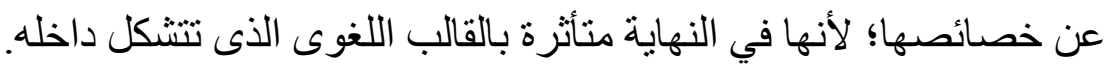

$$
\text { وبصورة تفصيلية، فإن تساؤلات الدراسة هى: }
$$

ا ـ ما الأسماء الأكثر و الأقل شيوعًا بيـن مو اليد المصرييـن

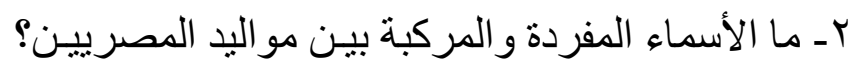

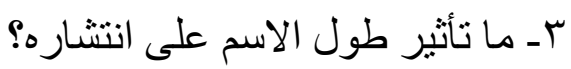

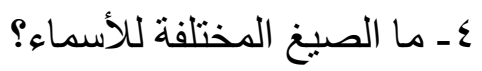

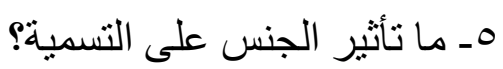

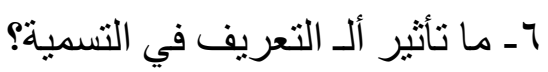

V- ما الأسماء التي ظهرت بعد موسو عة السلطان قابوس لأسماء العرب؟

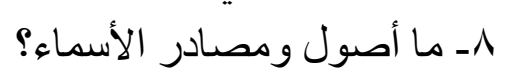

9ـ ما التصنيفات الموضو عية الأكثر شيو عًا في التسمية؟

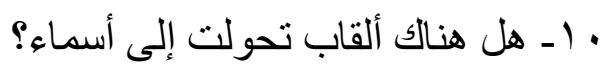

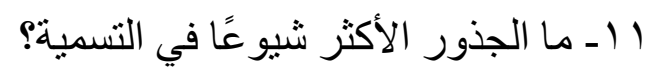

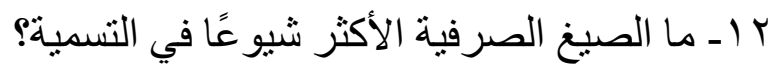

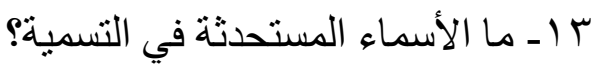




$$
\text { حدود الدر اسة و أبعادها: (o) }
$$

الاسم قد ينتشر بسبب أكثر من عامل، والدر اسة تتناول العوامل الكامنة في الاسم نفسه دون

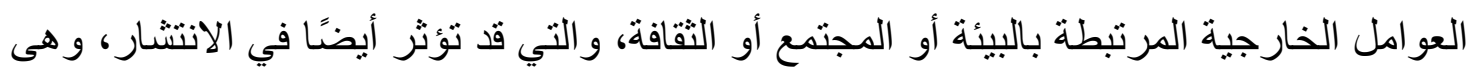

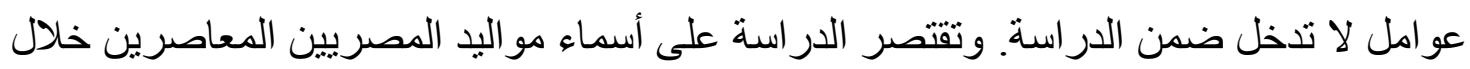
الفترة من عام 990 و وحتى عام ع . . Y.، باعتبار ها الفترة التي تقابل طلاب الثهادتين الابتدائية

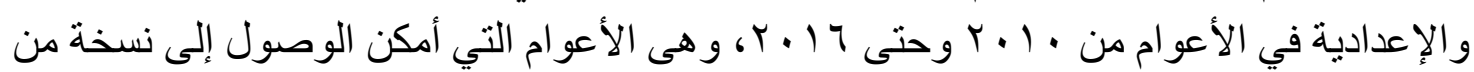

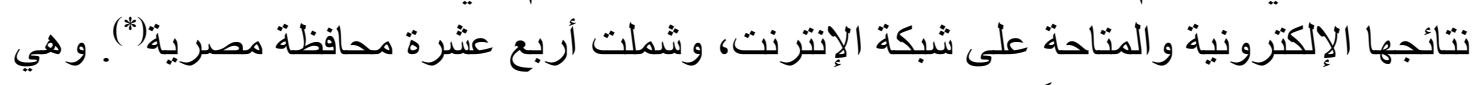
تتضمن معلوماتٍ حديثة نسبيَّا. وفى إطار الحدود اللغوية، اعتمدت الدر اسة على الأسماء المكتوبة باللغة العربية حتى ولو كانت أجنبية أو غير عربية الأصل. و اقتصرت على الاسم الرسمى فقط دون اسم التدليل أو اللقب التب التبه

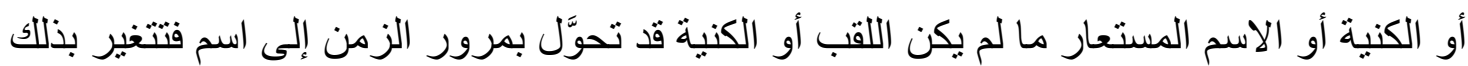

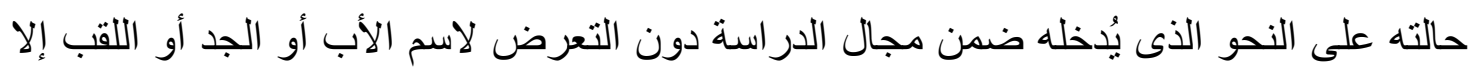

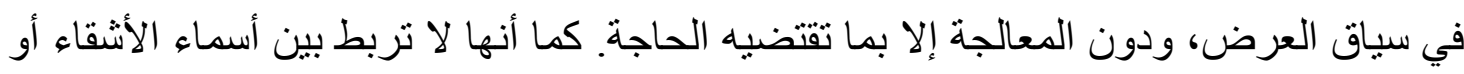

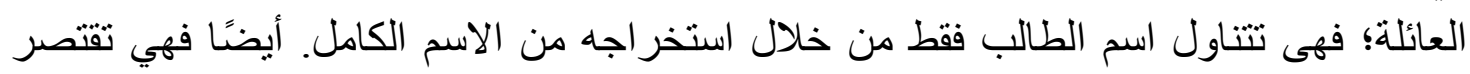
على ما يقدمه الاسم نفسه من معلوماتٍ دون عناصر خارجية مع الاستعانة بالإحصاء و أحيانًا

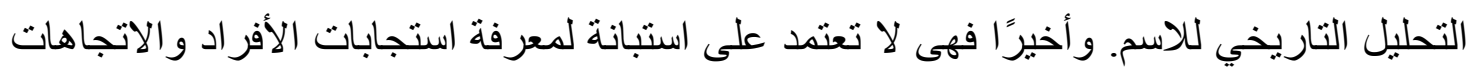
و الآراء و الدو افع ور اء التسمية.

$$
\text { (7) منهج الدراسة و أدو اتها: }
$$

اقتضت طبيعة الدراسة وأهدافها أن يكون المنهج البيليومترى هو المنهج المناسب لار اسة خصائص وسمات الأسماء؛ باعتباره يعتمد على القياس الإحصائى لظاهرة أو لظو اهر معينة من لهن

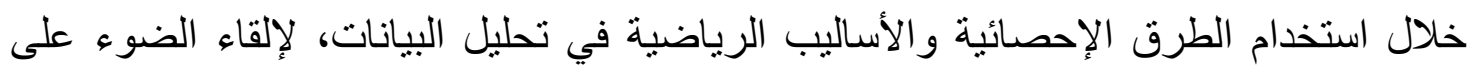
خصائص عمليات تداول المعلومات(ْ). بداية من وصف وتسجيل و اقع الظوالهر مرورًا بتأويلها

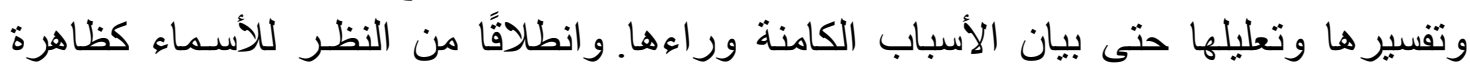

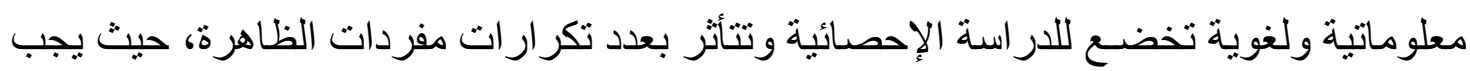

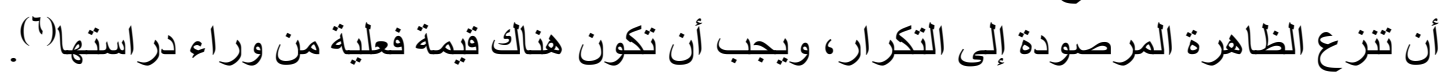
واستخدام المنهج البليومنري جاء لكونه منهجًا كميَّا يقوم على جمع المادة ميدانيَّا وتحليلها وتفسير ها، حيث تتحول الأسماء إلى قيمٍ رقمية فيكون الرقم السبيل للوصول إلى الى العناصر اللى اللغوية

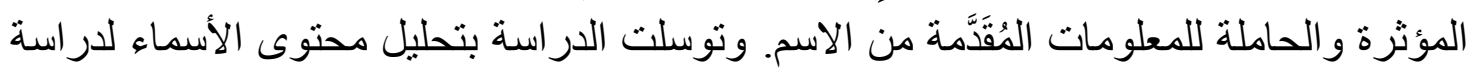

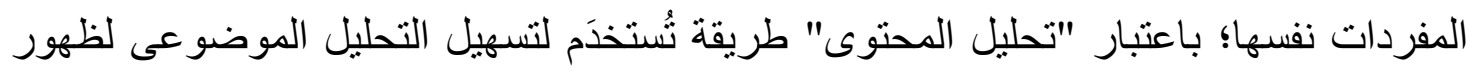
الكلمات أو الجمل أو المفاهيم أو الثخصيات، أو حتى الفقرات المحتواة، وهو ما يمكن بواسطته 
الاعتماد على الأوجه الكمية، وليس الأوجه الوصفية(').

ويعتمد البحث على "إحصاء النص" أو "قياسات النص" أو ما يمكن القول عنه إنه مزيجج من النه

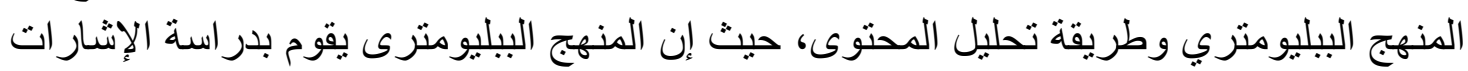

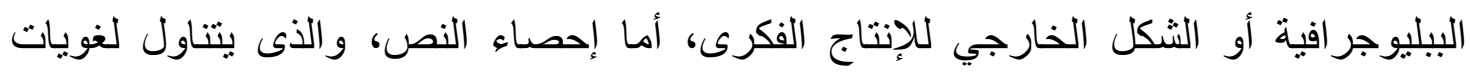

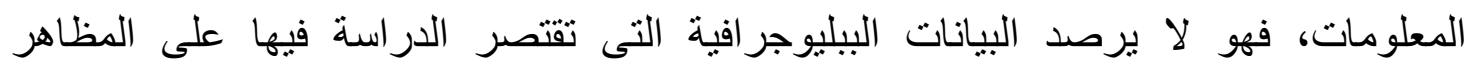

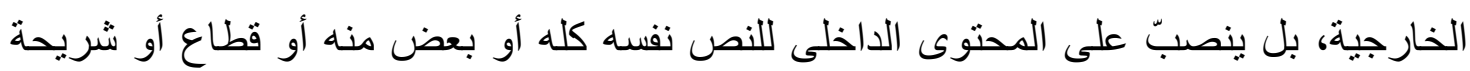

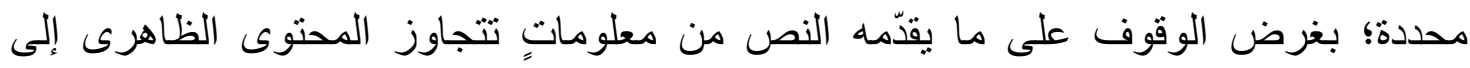

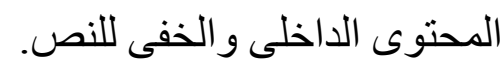

أما الأدوات التي استُخدِت في الدراسة، فثملت قاعدة بياناتٍ لرصد الأسماء داخلها

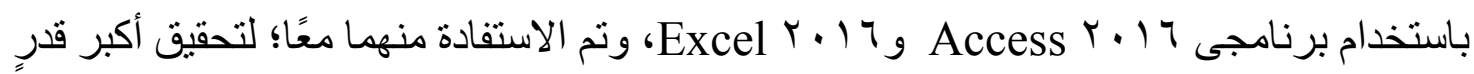
ممكن من التحليل. المجتمع الأصلى و عينة الدر اسة:

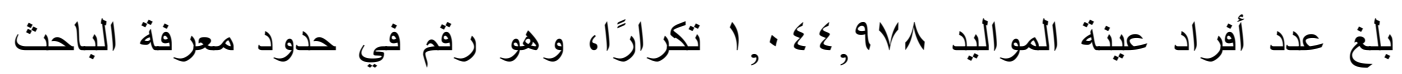

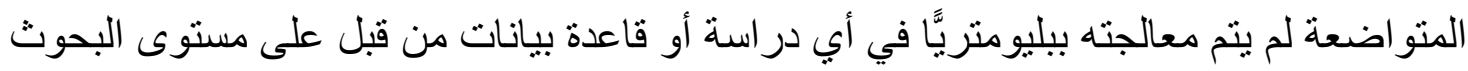

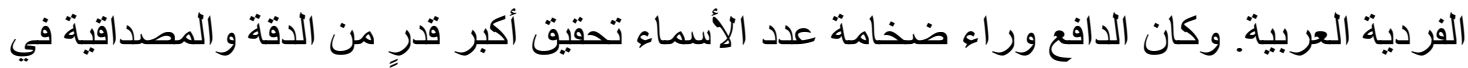

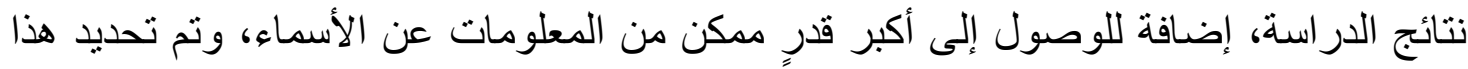

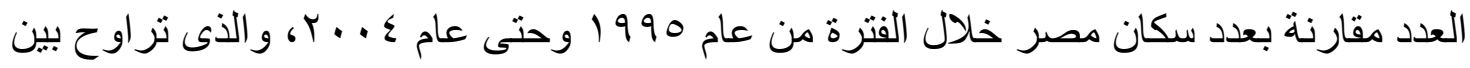
1

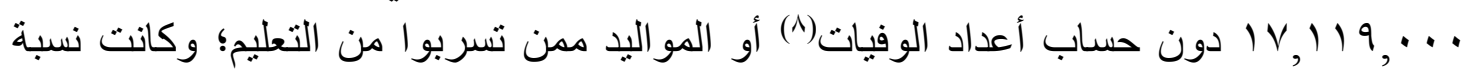

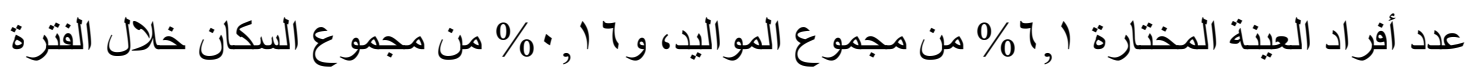
المذكورة.

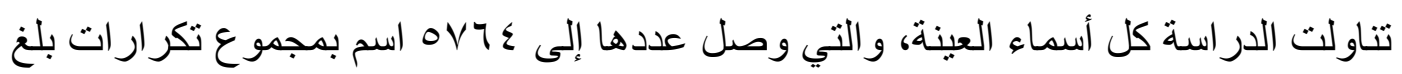

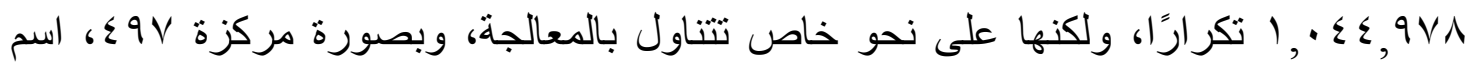

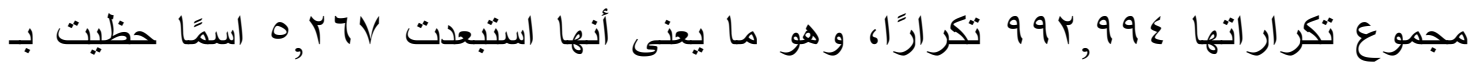

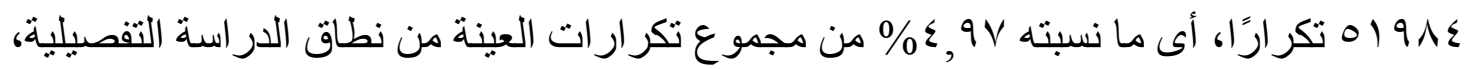

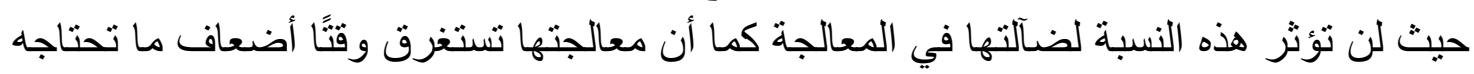

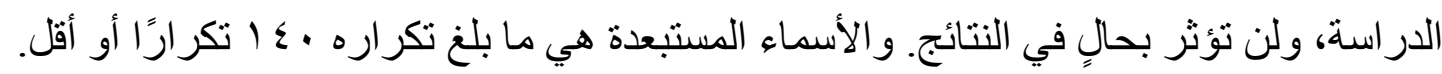




\begin{tabular}{|c|c|c|c|c|}
\hline$\%$ & تكرارات الأسماء & $\%$ & عدد الأسماء & الفئة \\
\hline$\% 90 . \cdot r$ & $99499 \leq$ & $\%{ }^{\wedge} .7 Y$ & $\sum 9 V$ & أسماء الاراسة \\
\hline$\% \leqslant .9 \vee$ & $0191 \leq$ & $\% 91 . r \wedge$ & orty & أسماء مستبعدة من المعالجة التفصيلية \\
\hline$\% 1 \ldots$. & $1 . \leqslant \varepsilon q \vee \wedge$ & $\% 1 \ldots$. & OVT & المجموع \\
\hline
\end{tabular}

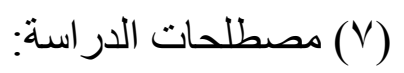

لغويات المعلومات: ذلك العلم أو الفرع من الدراسات الذى يدرس اللغة الطبيعية و علاقتها بالمعلومات؛ بهدف الحصول منها على المعلومات باعتبار القالب اللغوى هو الأكثر استخدامًا

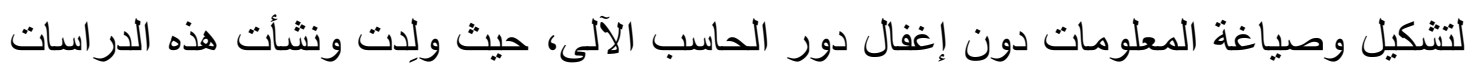
فى وجود الحاسب وفى ظل بيئة إلكترونية تتسم بمزايا وخصائص مغايرة للبيئة التقليدية المعروفة، بما يُمَكَّن ويُطِّّّع الحاسب من معالجة المعلومات و التوصل لها و التحقق منها. المجتمع الكلى: يُقصد به كل أسماء مو البد المصريين خلال فترة الدر اسة.

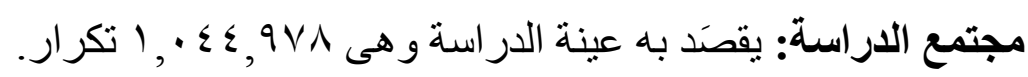
الاسم الكامل: هو مجموع الأسماء المفردة المكوّنة لاسم الطالب متضمنة اسمه و واسم أبيه واسم جدهو اللقب، وهو اللبنة الأساسية في حصر الاسعاء العينة. الاسم المفرد: هو أحد مكونات الاسم الكامل: اسم الطالب نفسه أو و الده أو جده أو عائلته، سواء

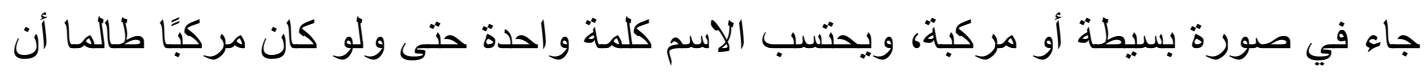
صيغته تقطع بكونه مركبًا. الاسم (الاسم الأول): الاسم المفرد للمولود دون اسم والده، وهو موضها موضوع الدر اسة الحالية. الاسم البسيط: اسم مفرد يأتي في صورة مكون و عنصر واحد. الاسم.

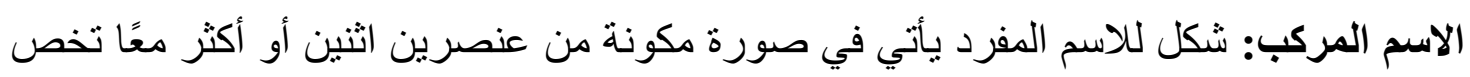
اسم الطالب أو و الده أو جده أو عائلته.

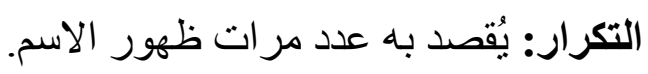

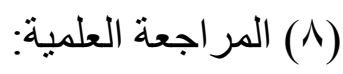
تم بحث الإنتاج الفكرى الأجنبي و العربى من خلال مر اجعة قو اعد البيانات العلمية الموجودة

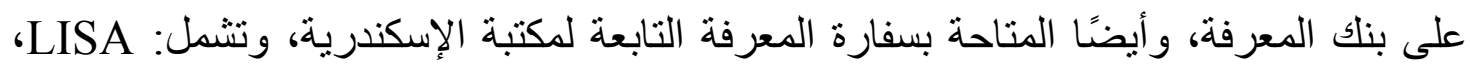
Springer ،ProQuest ،Eric

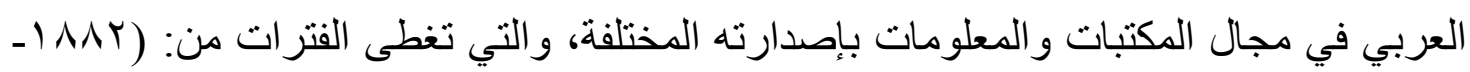

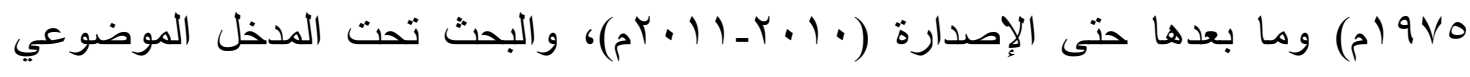


بيليومترى، وأسماء وتسمية، لم تسفر عملية البحث عن وجود أية دراسة سابقة عن الأسماء

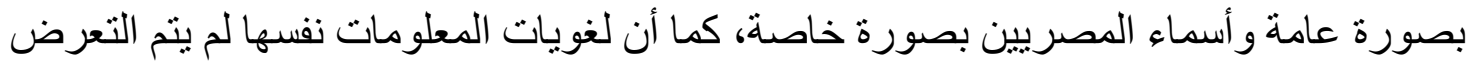
لها إلا ضمن سياق بحوث محددة كدر اسة حشمت قاسم "العربية في نظم المعلومات المتخصصة

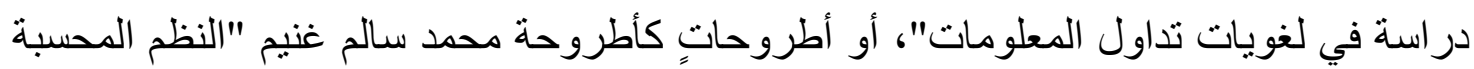

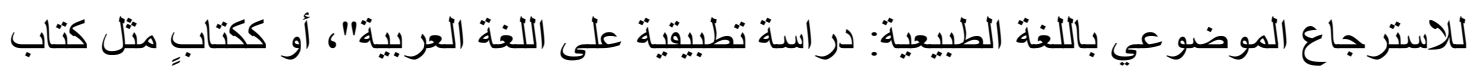

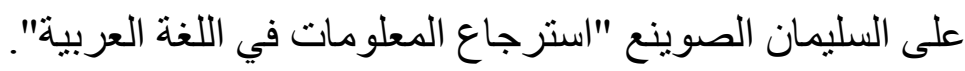
وتُعد الأسماء بوجهٍ عام و أسماء الناس على وجه خاص موضو عًا مشتركًا للعديد من العلوم،

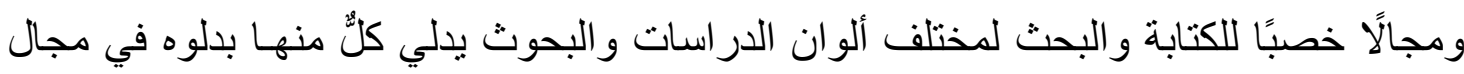
تخصصه و اهتمامه من الجو انب اللغوية و الاجتماعية و التاريخية و النفسية والإحصائية و الدر اسات الإسلامية وحتى المعلوماتية. ولم يكن للأسماء حظٌٌ من الدر اسة البيليومنرية، ولم تكن هناك در اسة

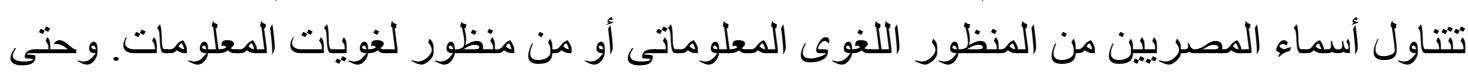

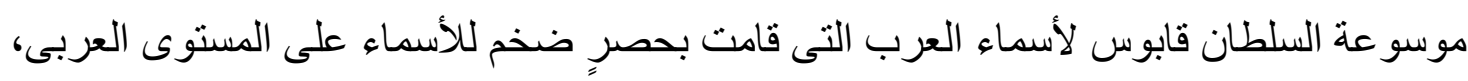
فإنها لم تتناولها إلا من المنظور اللغوى. وباقى الدراسات تناولتها من زوايا مختلفة: تاريخى

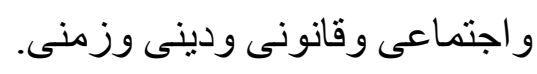

وجاءت أسماء الأشخاص فى در اسات المكتبات و المعلومات ضمن سياق معالجة الموضوع

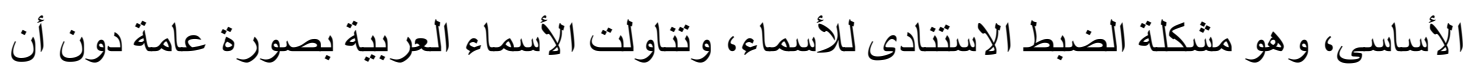

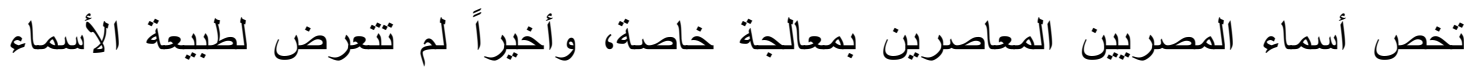
وخصائصها وسماتها فى إطار ها الكمى بما يمكن أن يفيد فى الدراسات المستقبلية الخاصة بالضبط الاستنادى وفى تحقيق أسماء المصريين المعاصرة وإعداد قواعد لصباغة الأسماء

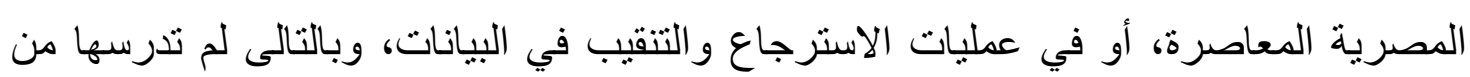
المنظور البليومترى الذى يظهر خصائصها وطبيعتها، ويوضح ثقل وقيمة كل اسمٍ منسوبٍ لتكر ارات وروده وظهوره بالمجتمع. واقتصرت جميعها على نماذج محدودة من الأسماء. ففى دارسة فوزى خليل الخطيب(9) بعنوان "مداخل أسماء الأشخاص فى فهارس المكتبات

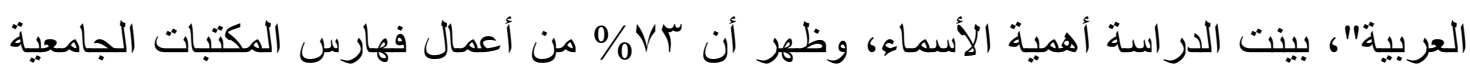

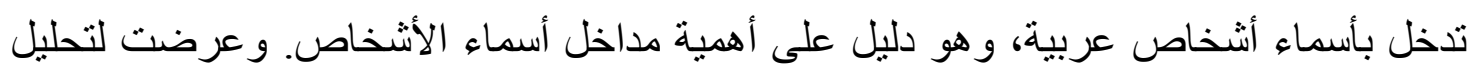

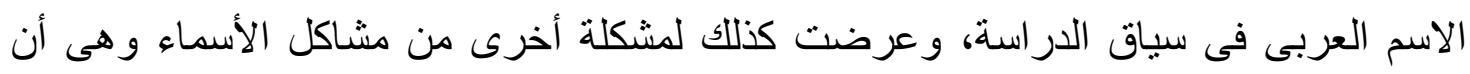

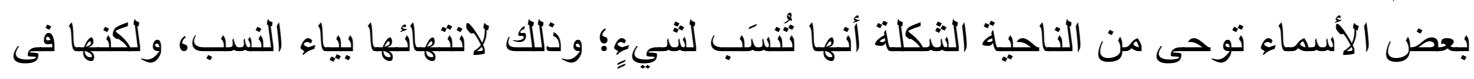

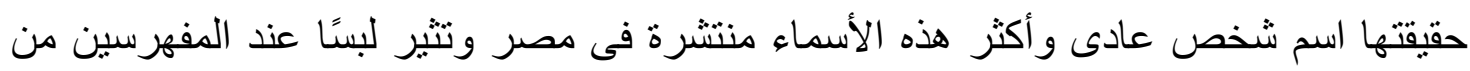
خارج مصر ، إضافة لمشكلة التفريق بين الأسماء القديمة و الحديثة. 
وقدَّم شعبان خليفة(·) فى در استه "المداخل ومشكلاتها فى فهرسة الكتاب العربي" عرضًا

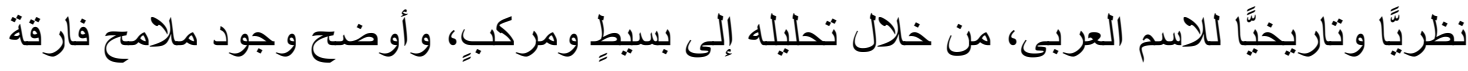

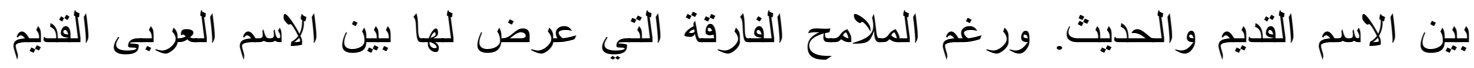

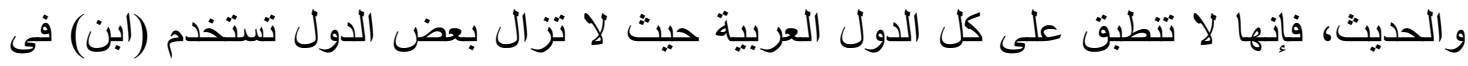
التسمية، ويستخدم البعض الآخر (بن)، وبعضهم أضافها كجزءٍ من الاسم، و هنالك من لا يستخدمها

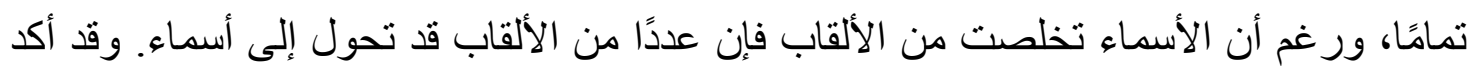
أن الحل العربى ينبع من طبيعة الاسم العربى. وإذا كان هناك اتفاق على هذا، فإن طبيعة الاسم

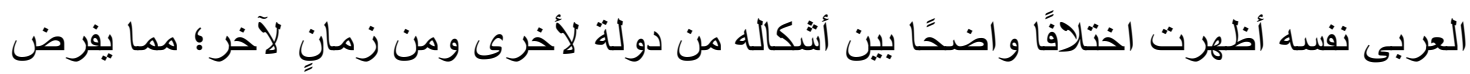

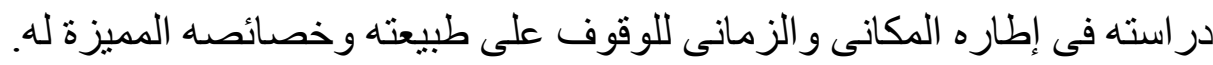

أما محمد فتحى عبدالهادى، فقد تناول المثكلة فى أكثر من دراسـة، فناقش فى الدراسة

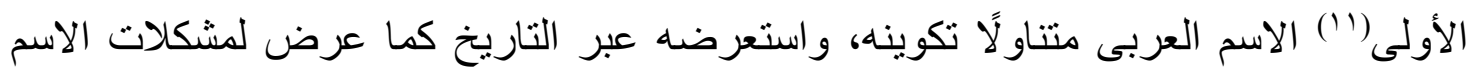

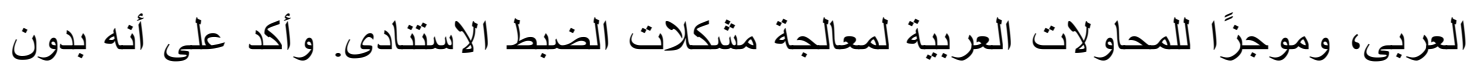
الضبط الاستنادى فإن نفس المشكلات المرتبطة بالفهرس البطاقي سوف تحدث في النظام الآلى؛

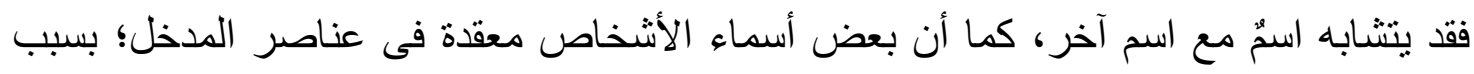

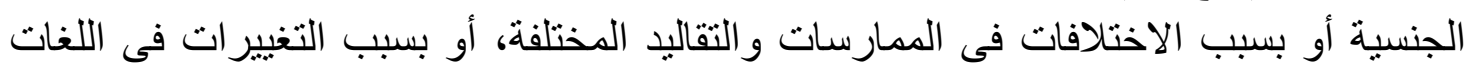

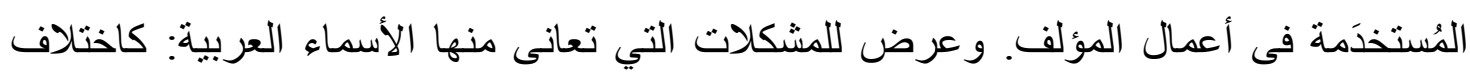

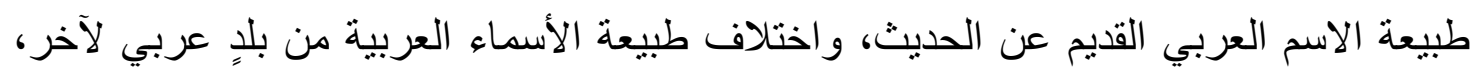

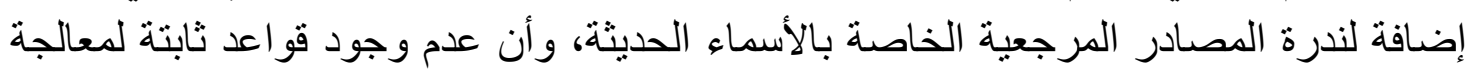
الأسماء العربية أدى لوجود حاجة لضبط الأسماء العربية للأشخاص. وتناول ثثلاث محاو لات تمث الأت

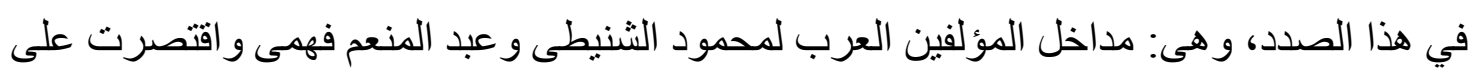

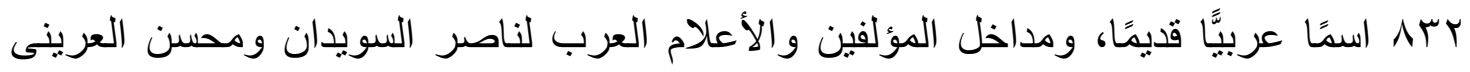

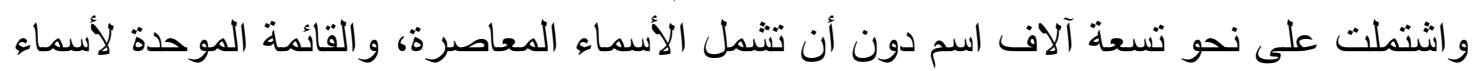

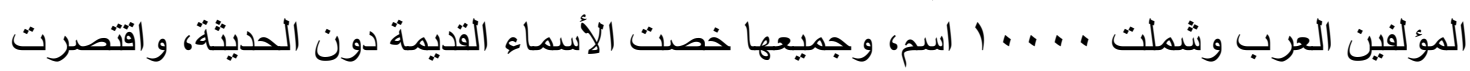
على عينات.

وفى الدراسة الثانية(r)'، عرض لما يواجه المفهرس عند تعامله مع الأسماء العربية من

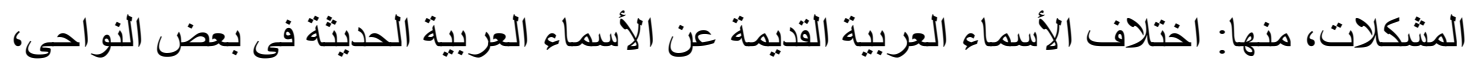

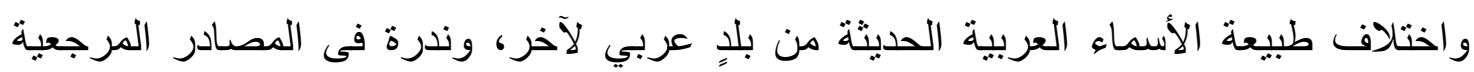

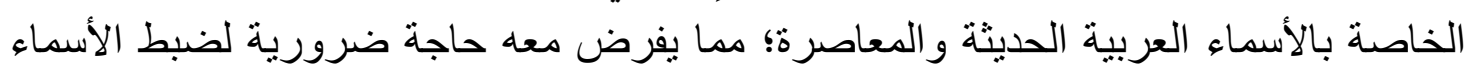
العربية للأشخاص قديمها وحديثها.

أما شمس الأصيل، فقد تناولت فى أطروحتهاج(1) ملفات الاستناد للأسماء العربية، و اعتمدت 
على مجمو عة كبيرة من الأسماء المصرية، و افترضت أن بها سماتٍ معينة تصلح لأن تطبق عليها مجموعة من القواعد المعيارية، ولكن الدراسة لم تتناول الأسماء من الناحية البيليومترية و اقتصرت على الانتقاء.

أما دراسة نزار محمد قاسم(£)(، فجاء تناولها للأسماء بصورة مختلفة؛ حيث عرضت الاءت

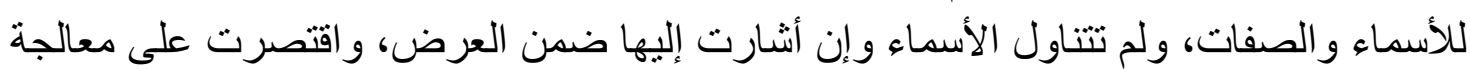

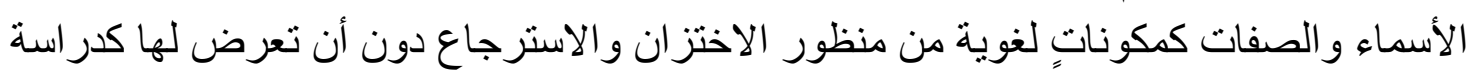
بيليو مترية.

وما سبق ليس عرضًا للضبط الاستنادى بقدر ما هو عرض لعدم وجود دراساتٍ تتعلق بالأسماء بصورة خاصة، و هو ما يجعل من موضوع الدر اسة قضية جديرة بالبحث. وفيما يلى عرض للار اسات التي تناولت الأسماء من خارج التخصص: دراسة سامية حسن الساعاتي(10) تتتاول الدراسة ظاهرة الأسماء والتسمية في المجتمع المصري، وتقدم تحليلً اجتماعيَّا

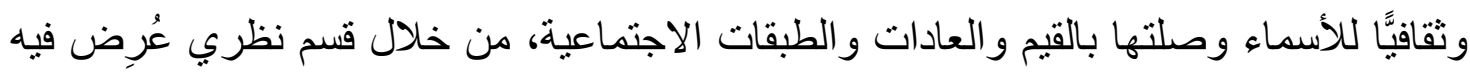
لمفهوم الدراسة وأهدافها وأهم الدلالات الاجتماعية للأسماء، وتاريخ عادات التسمية، وراعية، التحليل الاجتماعي للأسماء و علاقتها بالتغير الاجتماعي. وفى القسم المبداني تمت مناقثنة العلاقة بين

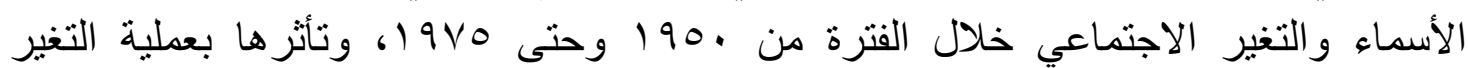
الاجتماعي داخل المجتمع المصري. من خلال فحص ديناميات الأسماء والتسمية في التقافة المصرية، والتعرف على التغيرات الاجتماعية في نفس الزمن وبين حقبتين زمنيتين للريف

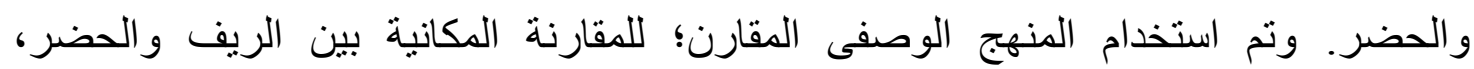

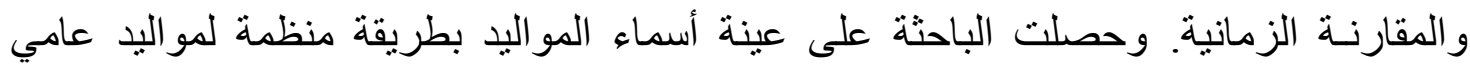
. 190 و 9V0 ام من و اقع سجلات مواليد إحدى قرى ريف المنوفية، وأخرى من أحد الأحياء الر اقية بمدينـة القاهرة، وكانت عينة الريف مائة اسم لكل عام، و وعينة الحضر مائتى اسم لكل عام.

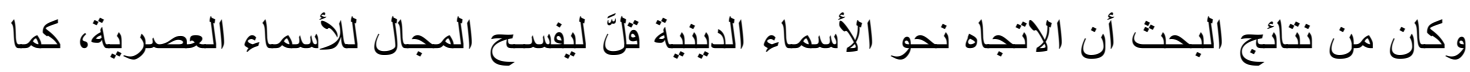

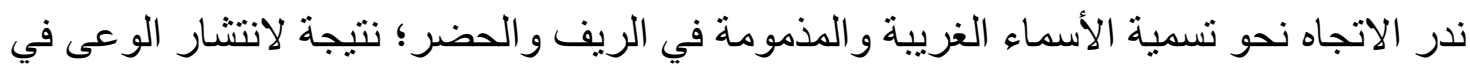

دراسة عاصم شحادة على (1)

تعرضت الدر اسة للتأثير ات الحضارية في الأسماء من ستة أبعاد: الدينى و البيئى والاجتماعى

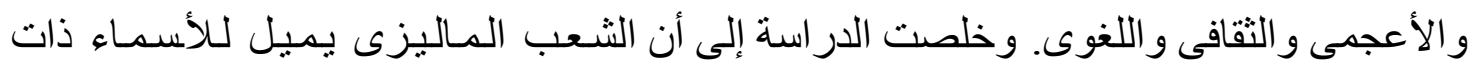
الدلالات الدينية، وأن ظاهرة تصحيح الأسماء تتم في أربع اتجاهات: من صحيح لصحيح، ومن ون 


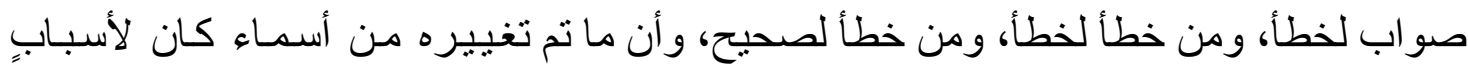
عقدية بسبب الارتداد عن الدين الإسلامى لتغيير الدين من الإسلامى إلى ديـانـة أخرى كالبوذيـة.

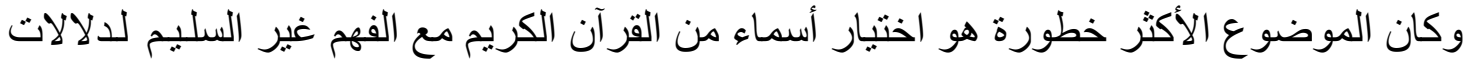

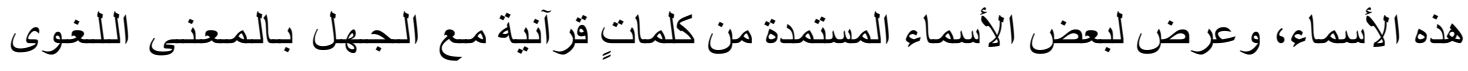
للاسم؛ لكون المعنى يحمل معانى قبيحة أو محرمة، مثل التسمى بأسماء: ز انية، نفخة.

\section{در اسة موسوعة السلطان قابوس لأسماء العرب('v')}

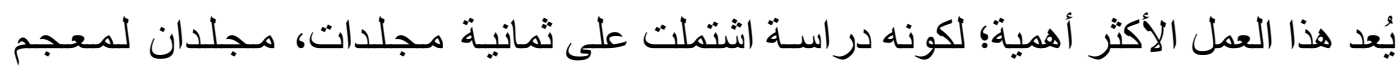

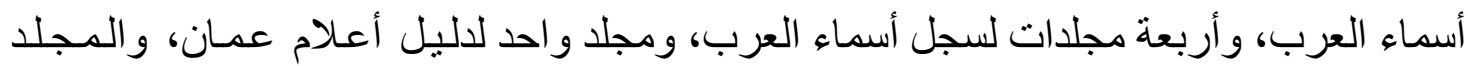

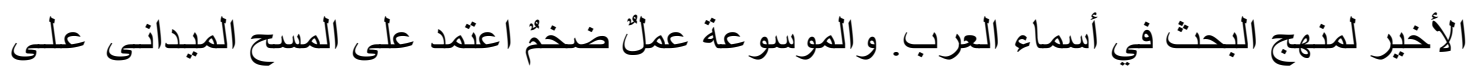

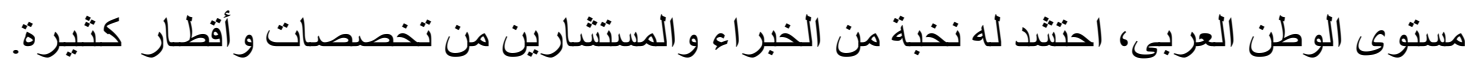

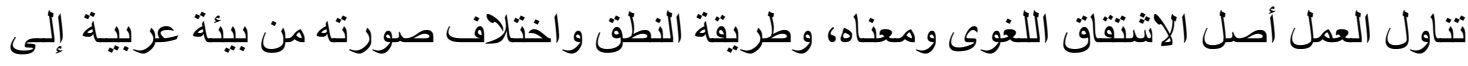

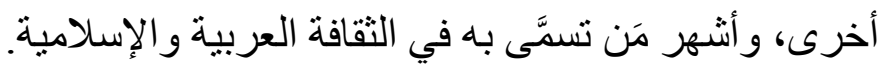

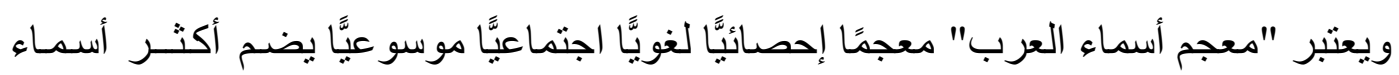

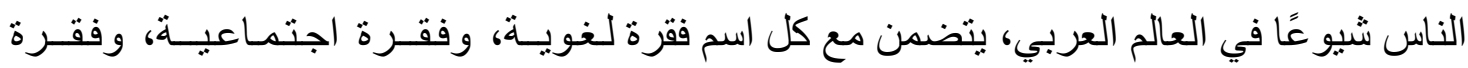

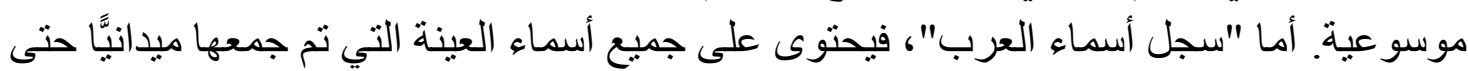

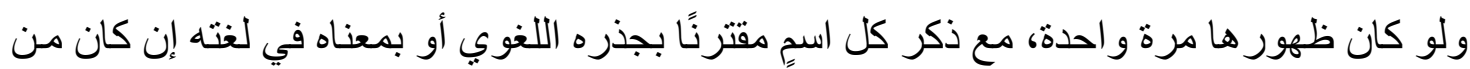

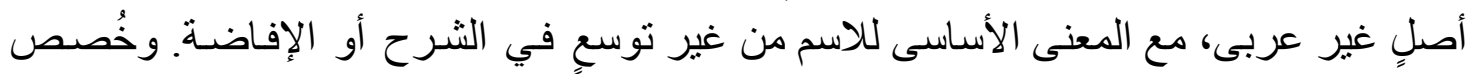

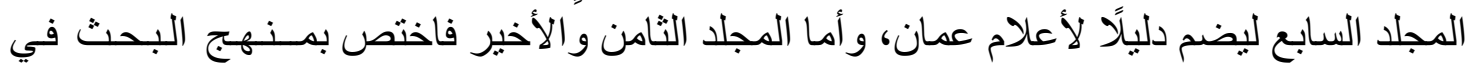
أسماء العرب، وتم فيه در اسة أسماء العرب و أهميتها و أصول در اسة أسماء الأعلام في التراث العربى و علم أسماء الأعلام ومنهج البحث ومصادر الدراسة. وتضمن المجلد دراسة مقارنة لنظم التسمية في البلاد العربية التى شملهاء البحثي.

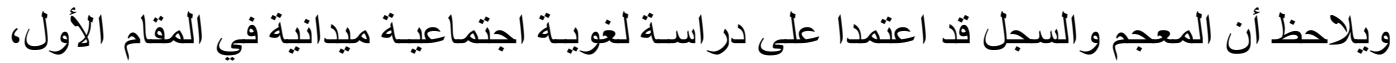

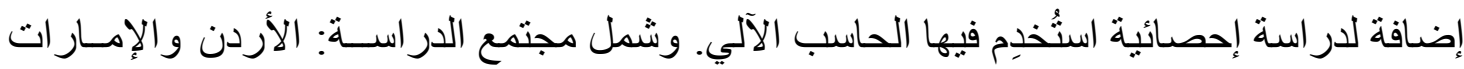

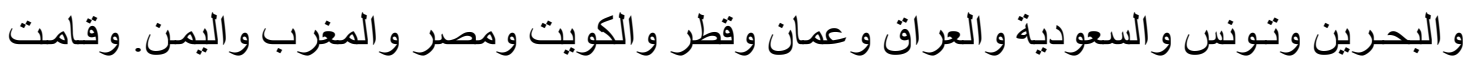

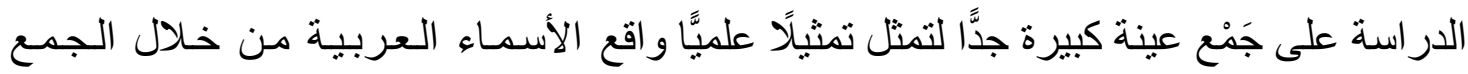

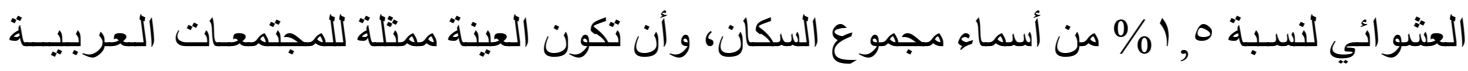

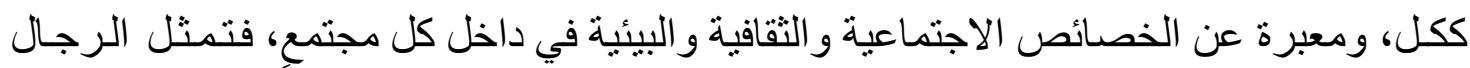

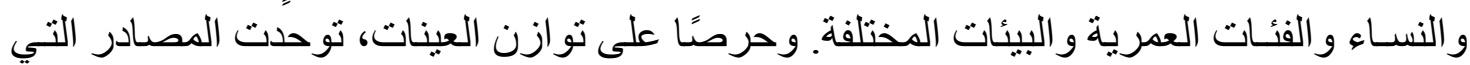

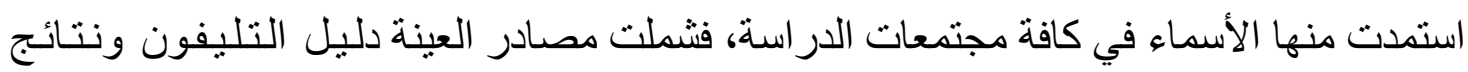
الناجحين وشهادات الميلاد ...إلخ، وتم أخذ نسبة متساوية من أسماء مجموع السكان في كل بلـٍ 


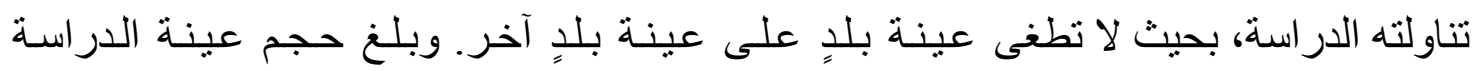

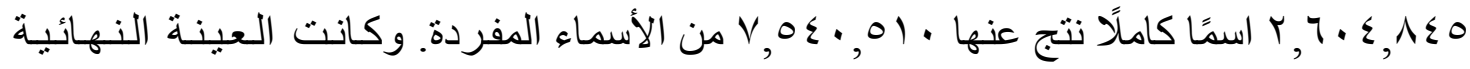

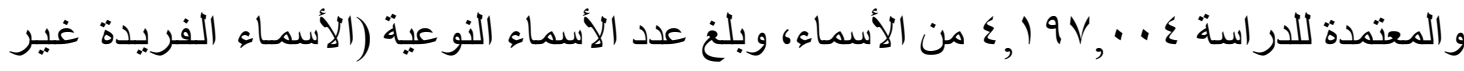

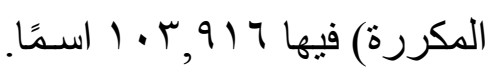

اعتمدت الدراسة على التحليل الكمي والكيفي وفقًا لمعايير مستمدة من علمى الإحصاء و الاجتماع اللغوى، من خلال استخدام الحاسب الآلي للتحليل الكمي والإحصائي بإخضاع التهاعي العينة

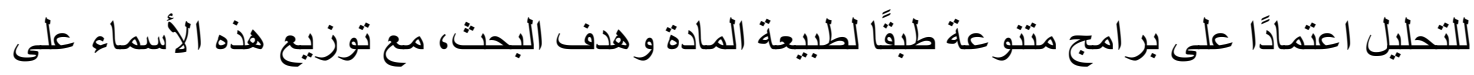

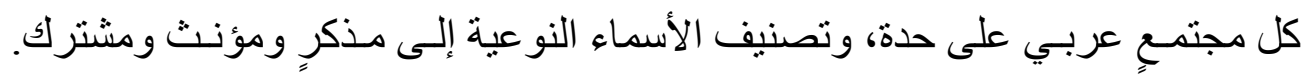
وفي ضوء التحليل الإحصائي: زودت الدراسـة كل اسمٍ بفقرة إحصائية تظهر عدد مرات

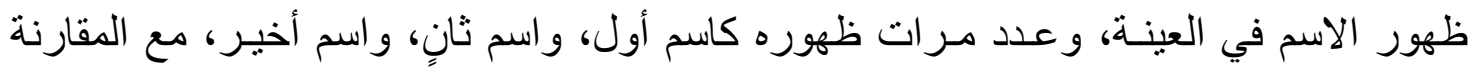

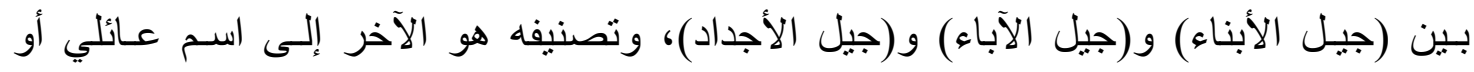
عثائري أو قبلي.

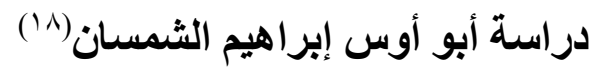

بحثُ ميدانى تناول أسماء الناس في المملكة العربية السعودية من جوانبها الاجتماعية

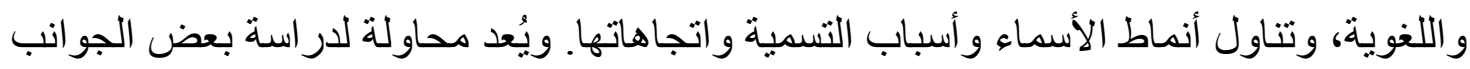

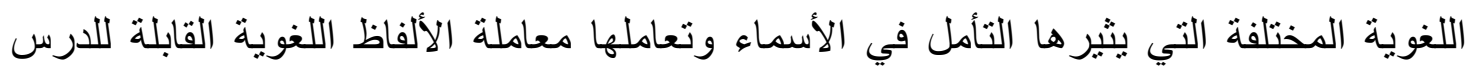

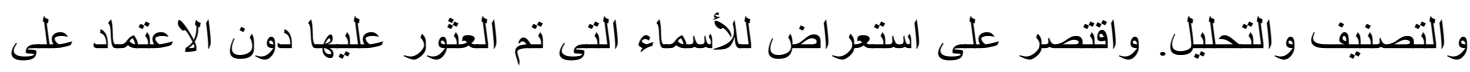

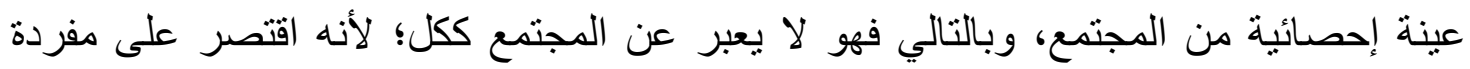

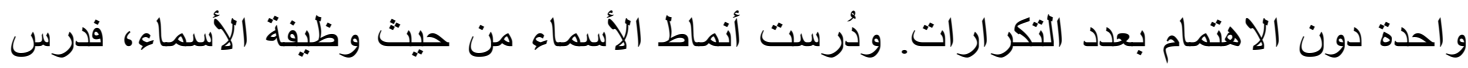

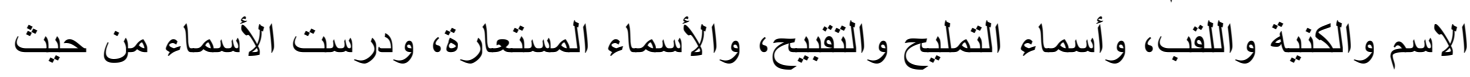
تصرفها، ومن حيث بنيتها، ومن حيث الجنس.

\section{دراسة بكرى محمد الحاج(19)}

حاولت الدراسة الوقوف عند الأسماء التى كان منطلق اختيار ها راجعًا إلى الدين و العقيدة

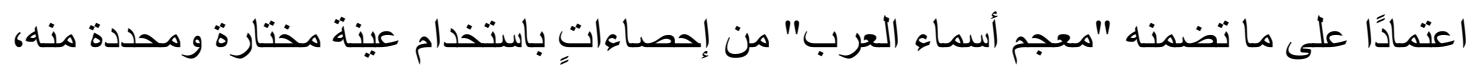

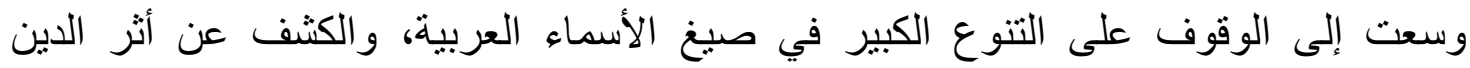

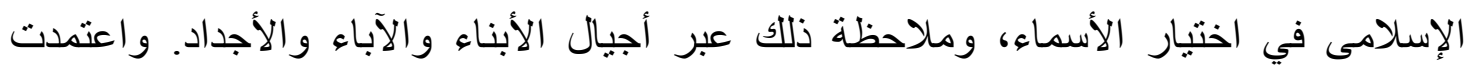

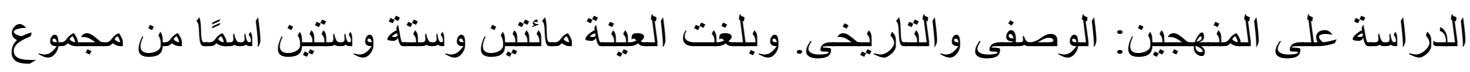

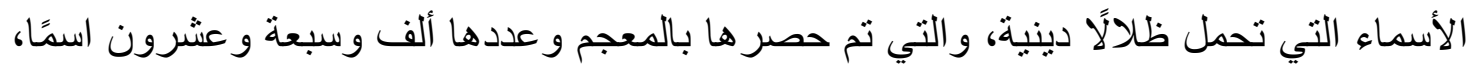

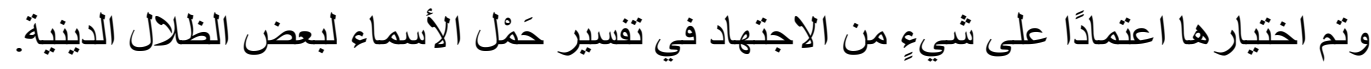


وحوت عينة البحث أسماء تسعة و عشرين نبيَّا بنسبة ؟9, • (\%)، كما حوت على الأسماء

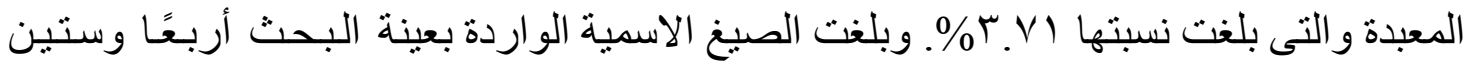

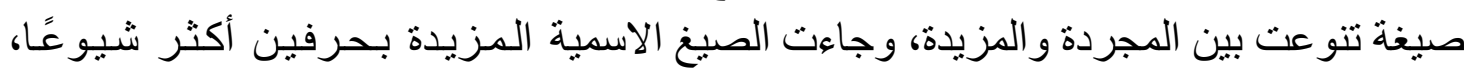
و الرباعية المجردة الأقل شيوعًا.

دراسة سنايمان وجينسين(r) (ب)

قامت الدر اسة على مقارنة نموذج تقليدي للتحكم في صياغة الاسم (برنامج تعاوني لصياغـة الاسم NACO ناسو) و(رقم المؤلف الدولي المعياري لتوحيد الأســاء ISAN إسـان). ويـتهـد

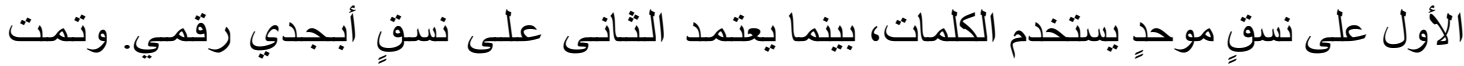

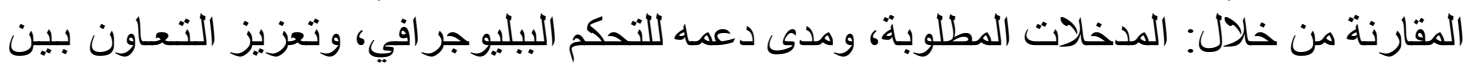

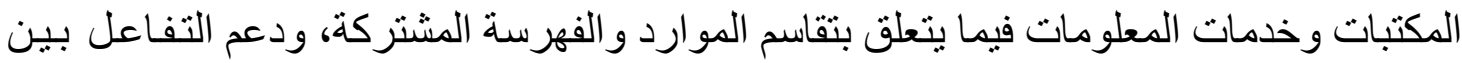

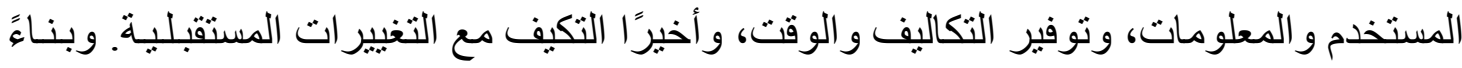
على هذه النتائج تم اقتر اح طريقة أكثر فاعلية لتوحيد الأسماء. و أتاح NACO ناسو تتفيذ المـهام

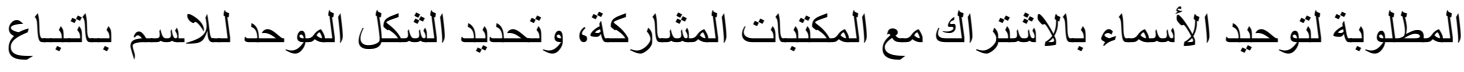

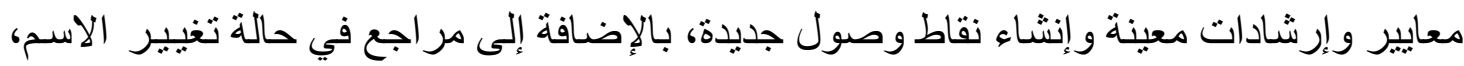

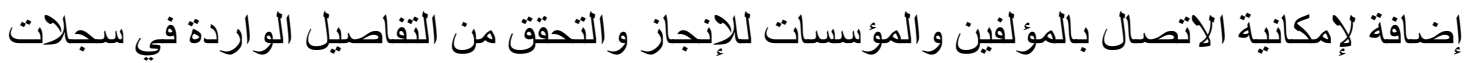

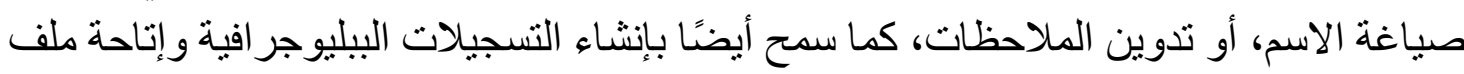

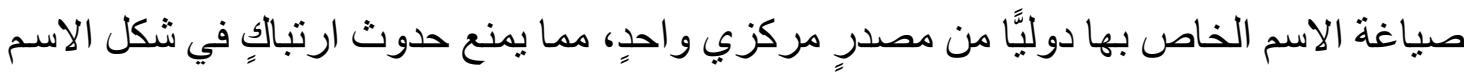

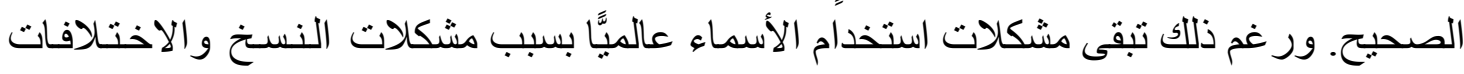
اللغوية، والاختلافات بسبب العادات الببليوجر افية الوطنية المختلفة. وتظهر المقارنة أن الأداء العام لنموذج ISAN إسان أفضل بكثير من أداء NACO مأسئ.

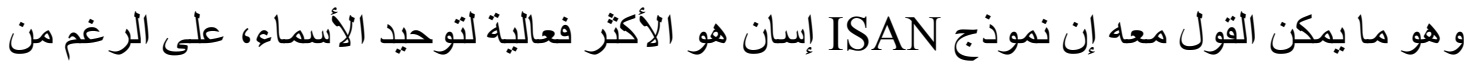

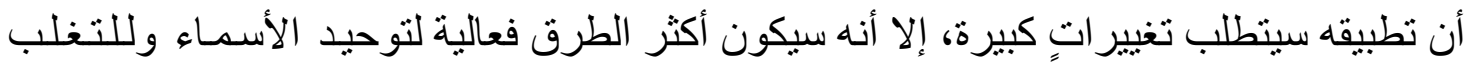

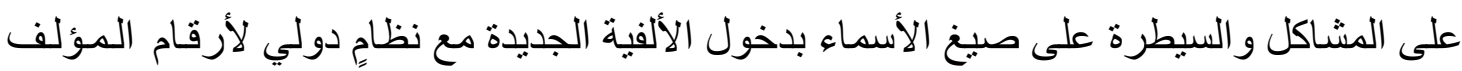
القياسية.

\section{دراسة جون كوتون وآخرون(r)'}

سعت الورقة إلى در اسة تأثثير التفرد و العِرق للأسماء الأولى على ردود الفعل العاطفية لتلك

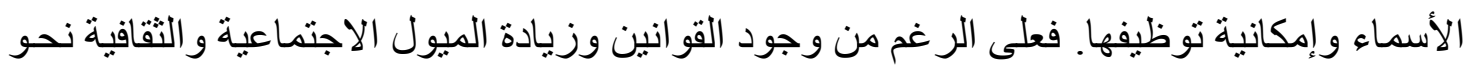

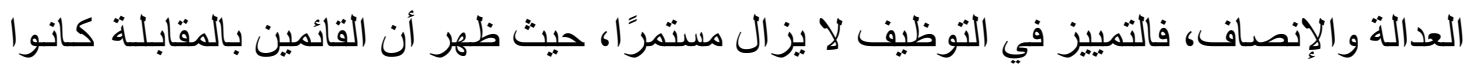

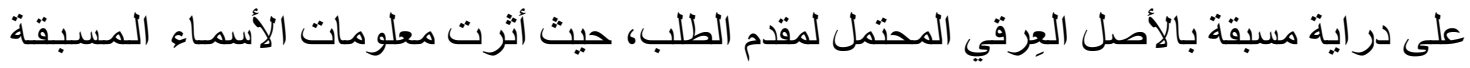
على الاختيار، وتم الاستبعاد من خلال المعلومات الموجودة في خطاب التقديم أو السيرة الذاتية، 
فكان بالإمكان معرفة أصل الثخص قبل مقابلته، استنادًا إلى اسمها، و هو ما يؤثر على ردود الفعل الفحل

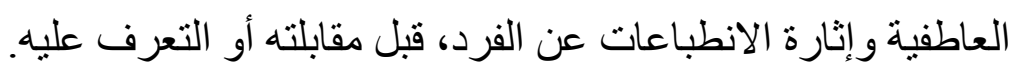

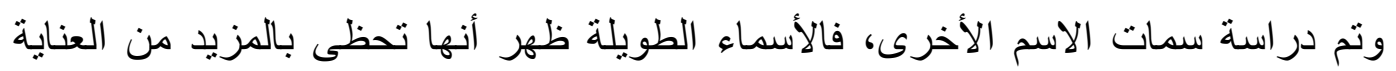
الأخلاقية، والمزيد من النجاح، والأسماء النادرة تم تصنيفها على أنها أقل في المرتبة من الأسماء

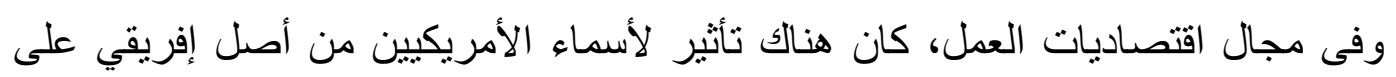

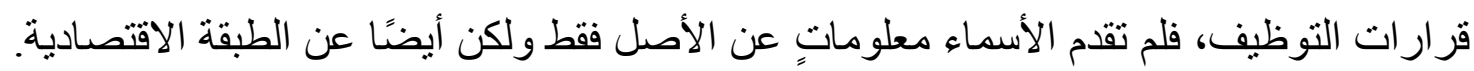

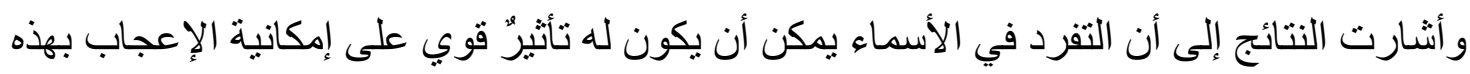

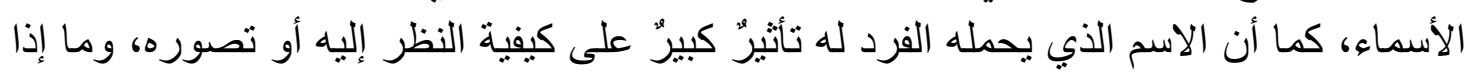

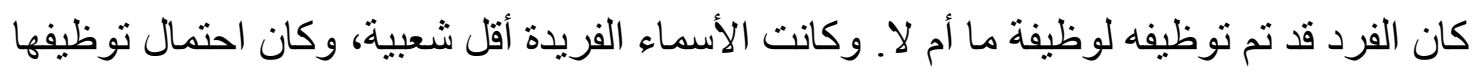

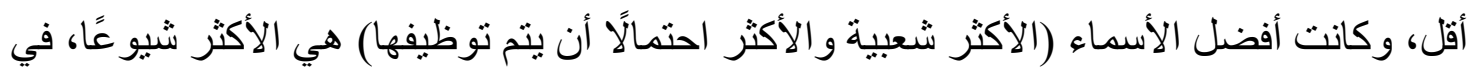

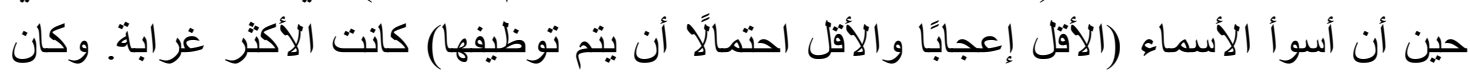

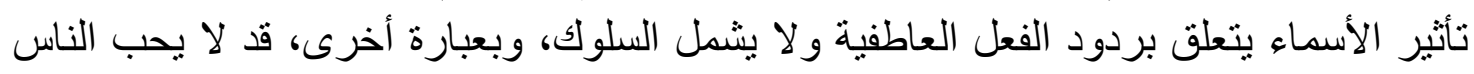

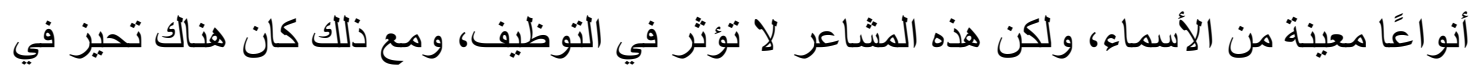
بعض الأحيان لمجمو عة متنو عة من الأسماء الفريدة.

\section{دراسة جميس بويل وآخرون(r)}

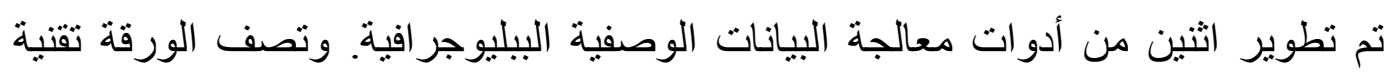

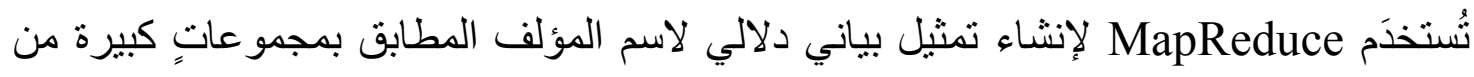

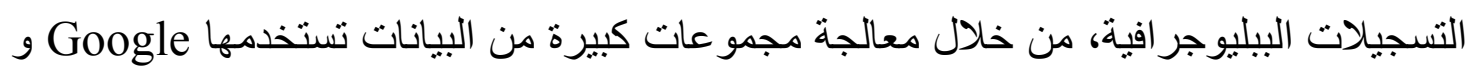

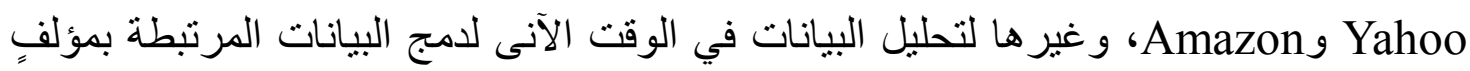
واحدٍ، و التي قد تتشأ في مجمو عاتٍ كبيرة من البيانات.

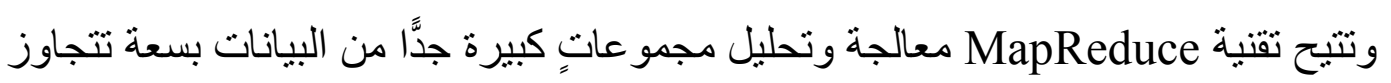

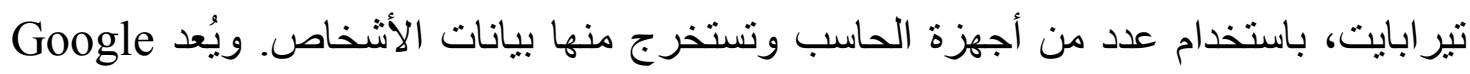
أحد مطورى هذه التقنية في جهوده لفهرسة صنحة التحات الويب.

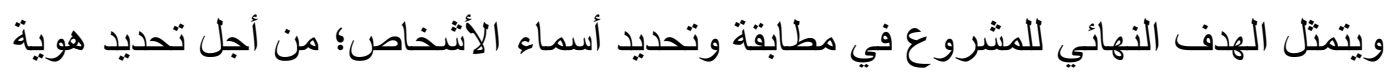

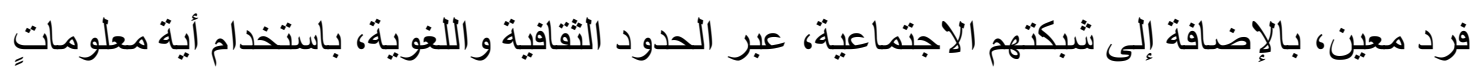

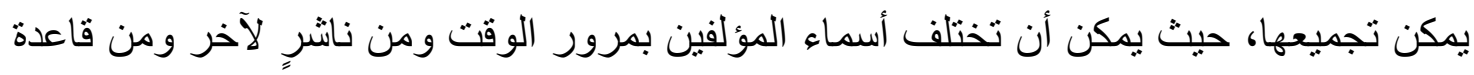

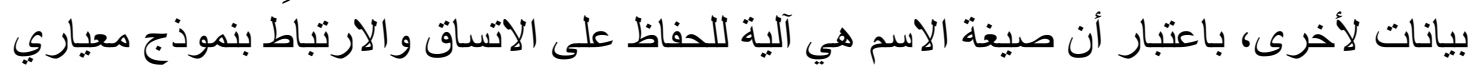

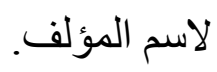


وقد تمت معالجة ملف بحجم Y,Y جيجا بايت يحتوي على أكثر من ^, 1 مليون تسجيلة

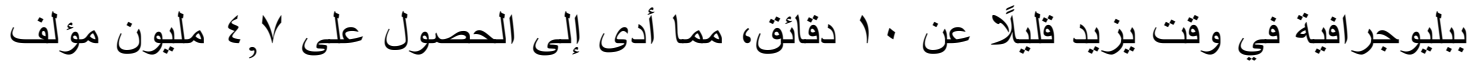
فريد. ولكن ما يجب أن يؤخذ في الاعتبار أن مصادر البيانات لن تكون جميعها سجاتات

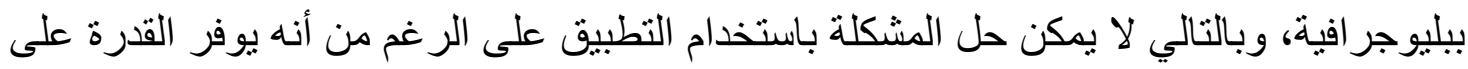
التعامل مع البيانات الكبيرة.

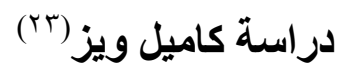

التتبؤ بالجنس ليس سهلً كما قد يبدو، كما أن فئة الجنس لا تكون متاحة صر احة مما يتطلب

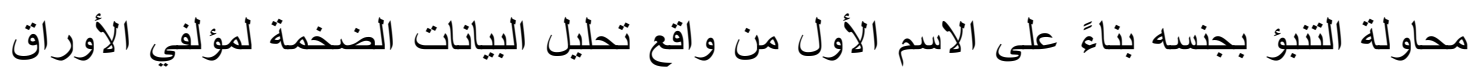
العلمية. ويتز ايد الاهتمام بطرق التنبؤ بالجنس على أساس الأسماء الأولى التي تستخدم المصادئ الأور المختلفة للبيانات المفتوحة مثل التعداد السكانى الأمريكي، وهذه الدراسات تطبق لإن الأساليب البيليومترية لصياغة وتقديم العروض التجارية لمستخدمي الويب، فيتم تحليلها مع إمكانية تحسينها

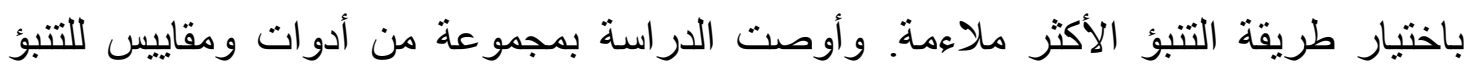

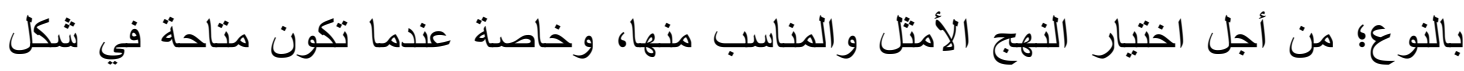
إلكترونى. ومع ذللك، فهناك نقص في دراسات التحقق من صحة ومدى كفاءة وفعالية الأساليب

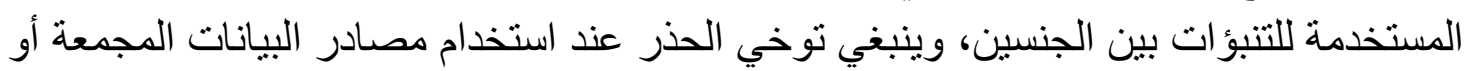

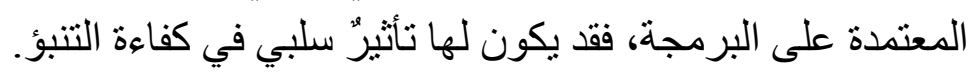

وكان هدف الدر اسة إيجاد طريقة للتنبؤ بالنوع الاجتماعي وتطبيقها تستند إلى الأسماء الأولى

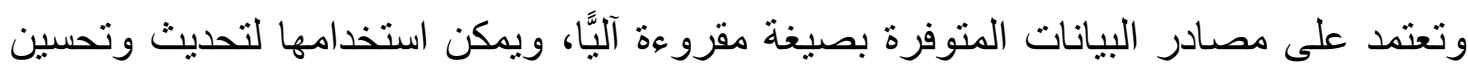
توقعات النوع الاجتماعي بمرور الوقت مع بيانات الاسم الأول الجديدة. تم استخدام التعداد السكاني في الولايات المتحدة كمصدرٍ رئيسٍ للبيانات المتعلقة بالتنبؤ

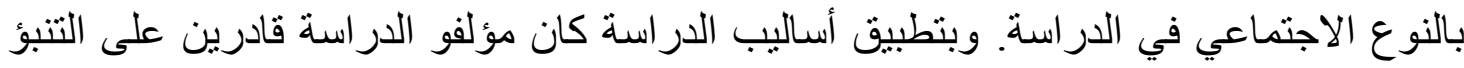

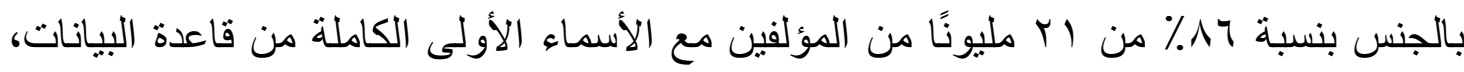

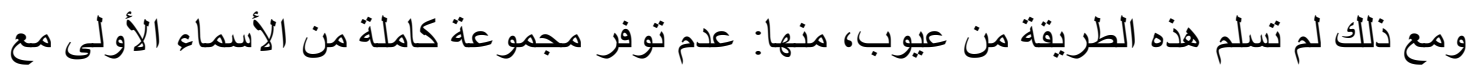

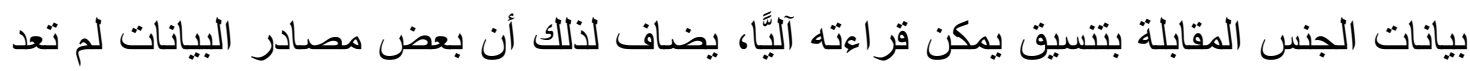

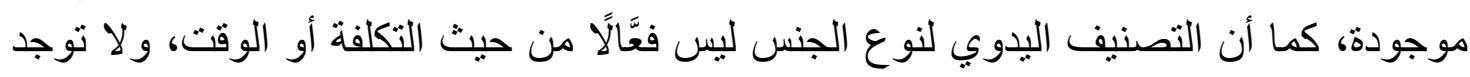

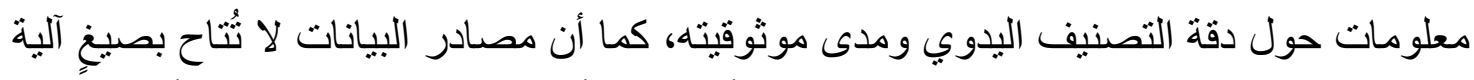

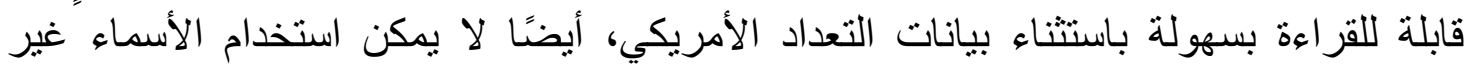

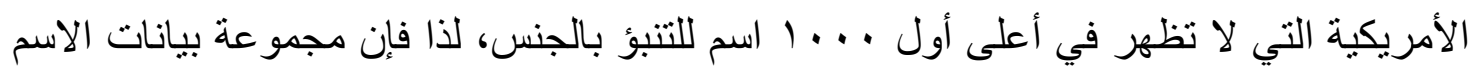

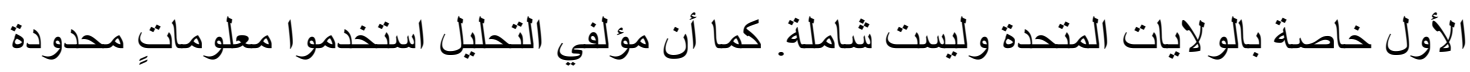
لأسماء أول . . . . طفلٍ، على الرغم من أن قاعدة بيانات أسماء الضمان الاجتماعي الأمريكي 
تتيح كل الأسماء التى تتجاوز تكر ار اتها خمس مرات وتتثمل السنوات من عام ، 1 1 حتى الآن وترصد تكرار اتها. وحتى يتم استخراج الأسماء، تمت معالجة النص بإز الة الحروف الفردية

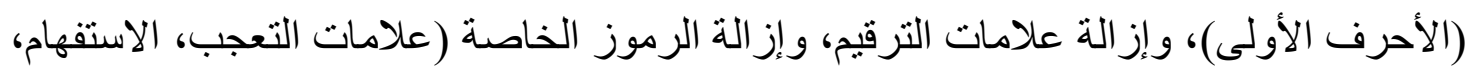
الو اصلات،..)، و إز الة الأرقام، وتحويل جميع الحروف إلى أحرف صغيرة، وتقليص المساحات

البيضاء.

بين الاراسة الحالية والاراسات السابقة والمثيلة:

بعد فحص نتائج البحث في الإنتاج الفكرى العربى والعالمى، يمكن الخروج بالمؤشرات

الدر اسة الحالية تمثل باكورة الإنتاج الفكرى في هذا الموضوع، ويؤكد هذا التفرد أن لغويات

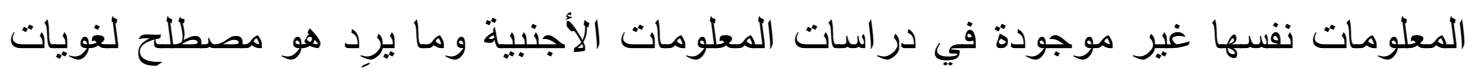

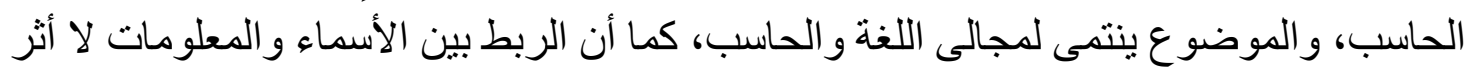
له فيما تم العثور عليه من هذه الوجهة.

تناولت الدر اسات و البحوث السابقة والمثيلة الأسماء، وتعرضت لها من نواح مختلفة، فجاء

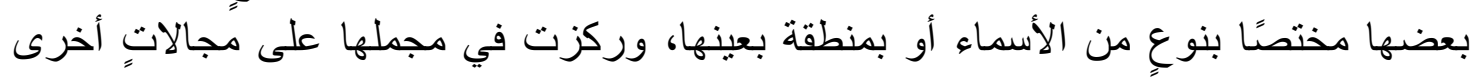

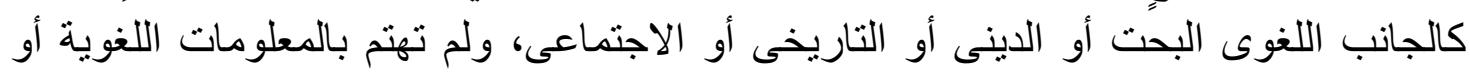
بلغويات المعلومات، ولم تنظر للغة من زاوية معلوماتية، ولم تتظر للمعلومات من زاوية لغوية.

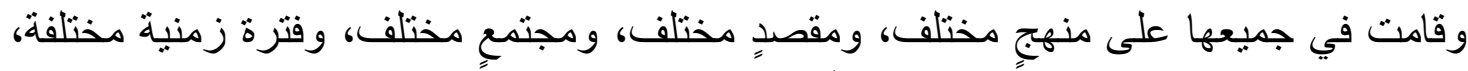

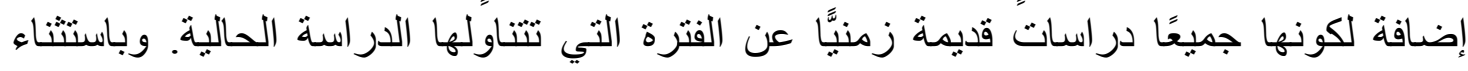

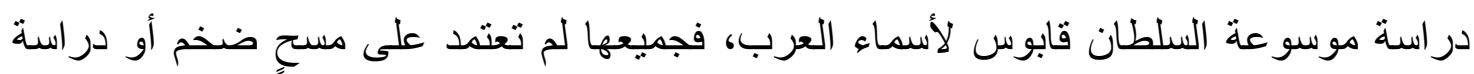

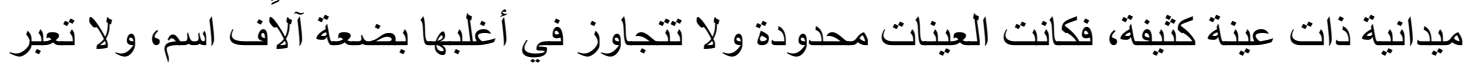

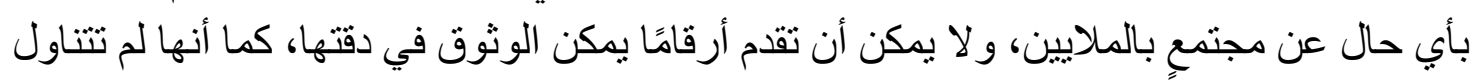

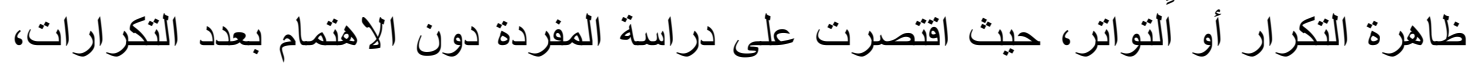

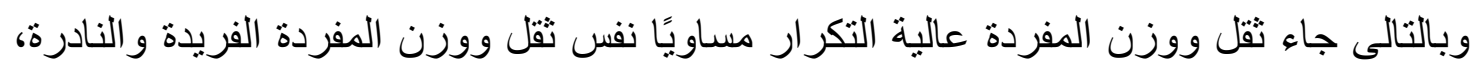

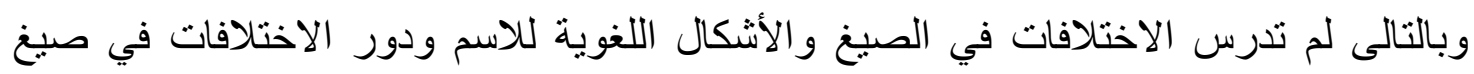

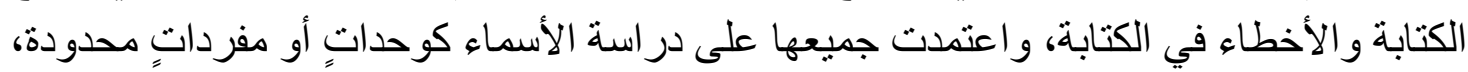
ولم تتعرض للأسماء ككل في إطار ها الكمى للخروج بدلالات معلوماتية، حتى موسوعة السلطان قابوس لأسماء العرب فاقتصرت على تناول الأسماء كما هي، دون بحثٍ في نأثير العناصر اللغوية في الاسم، وولا لدور المعلومات في التسمية ولا لأخطاء الأسماء أو التسمية. اعتمدت الدراسات على التحليل الكيفي فقط، عدا دراسة موسوعة السلطان قابوس لأسماء

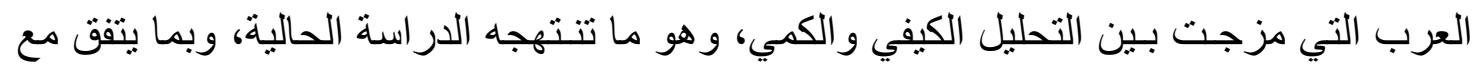




\section{طبيعتها.}

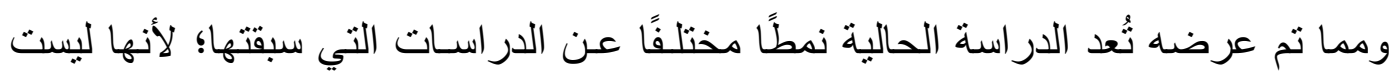

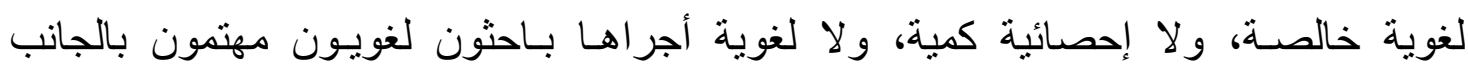
الاجتماعي، بل لغوية معلوماتية في إطارٍ إحصائى من خلال المنهج الببليومنرى والمنهج التحليلي، إضافة للتحليل اللغوى وتحليل المحتوى، أو بما اصطلحت عليه الدراسة "إحصاء النص" أو "قياسات النص" إنه".

ويُعد العمل الوحيد الذى تناول الأسماء بصورة موسعة هو موسو عة السلطان قابوس لأسماء

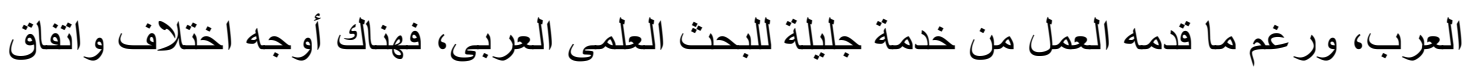

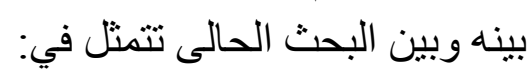
ا ـ تناولت موسوعة السلطان قابوس الأسماء من زاوية لغوية إحصائية، أما الدر اسة الحالية

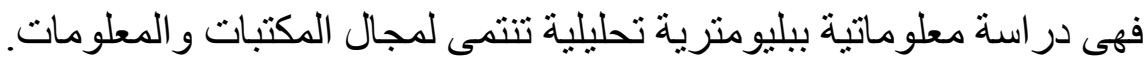

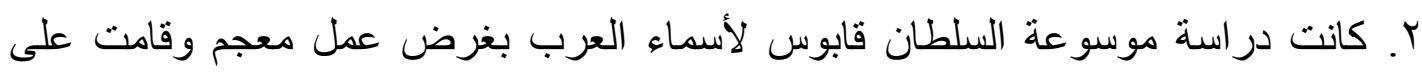
الإحصاء اللغوى، أما الدراسة الحالية فتنتمى لمجال المعلومات، ونات وتتناول ثثلاثة أبعاد:

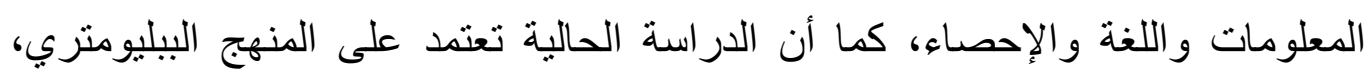

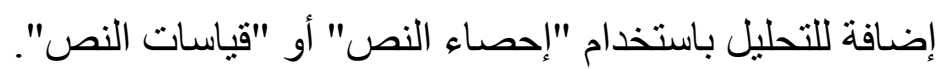

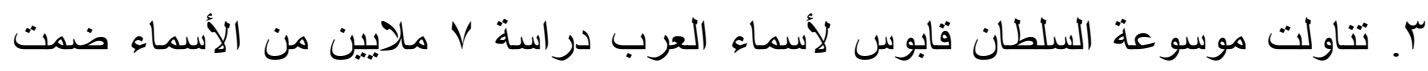

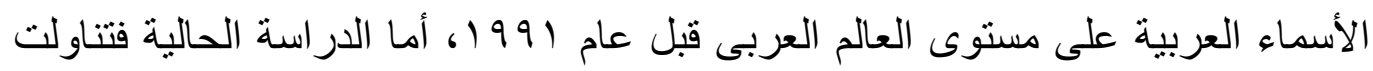
مليون اسم من أسماء المصريين المعاصرين من مواليد ما بعد سنة 1990 وحتى سنة

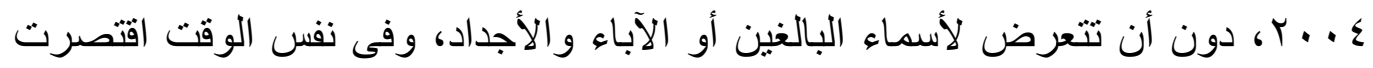
على الاسم الأول للمولود فقط.

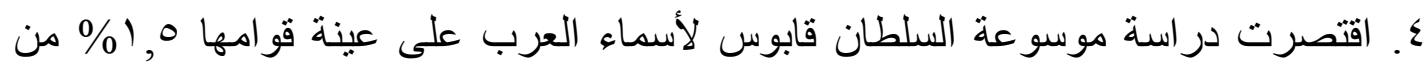

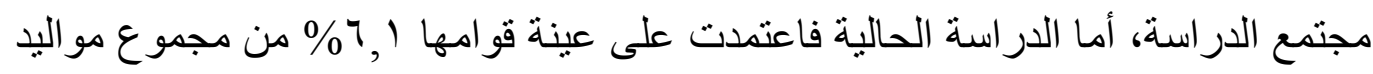

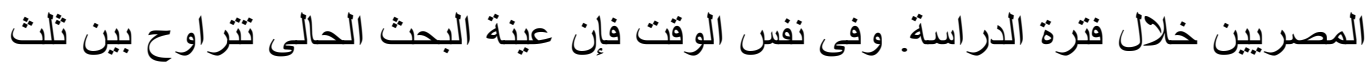
ونصف عينة موسو عة السلطان قابوس. ๑.اعتمدت الدر اسة الحالية على ملفات نتائج الثهادتين: الابتدائية و الإعدادية المصرية المتاحة

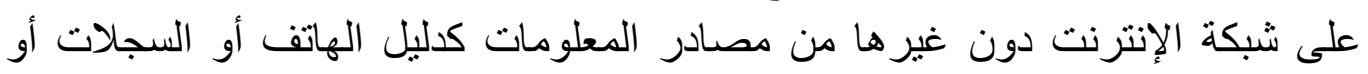
غير ها من مصنادر معلومات الأسماء المعتادة. T. جاءت موسو عة السلطان قابوس لأسماء العرب نتاج عملٍ جماعى مؤسسى دعمته سلطنة

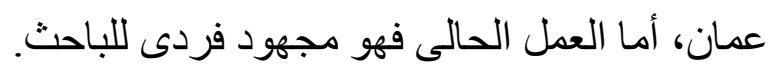




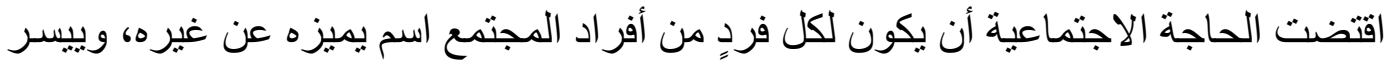

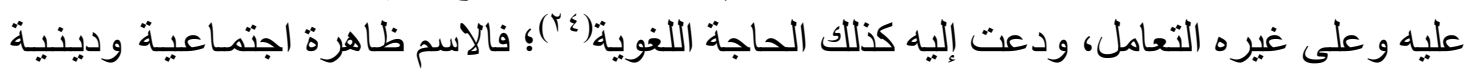

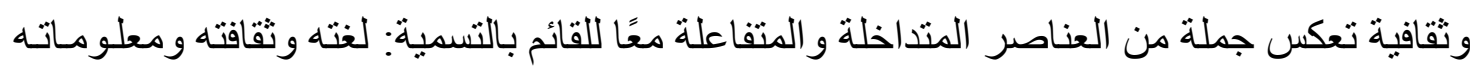

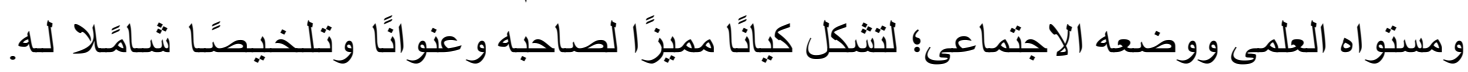

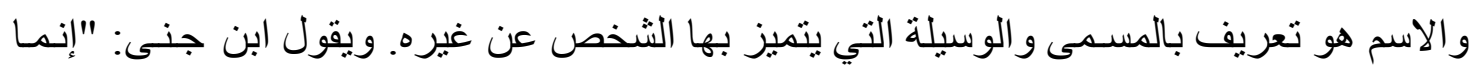

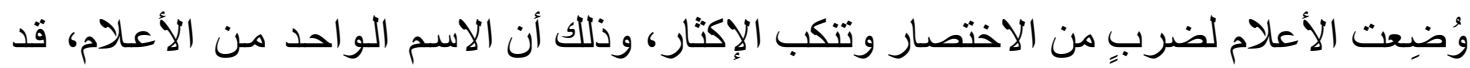

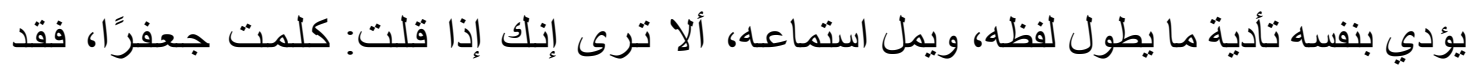

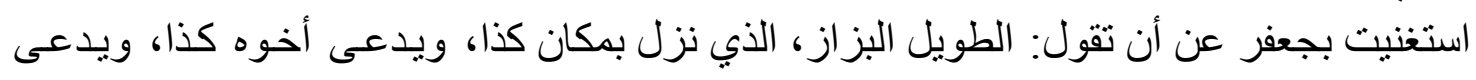

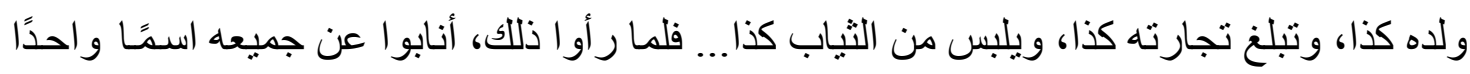

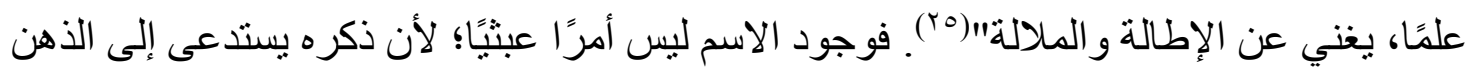

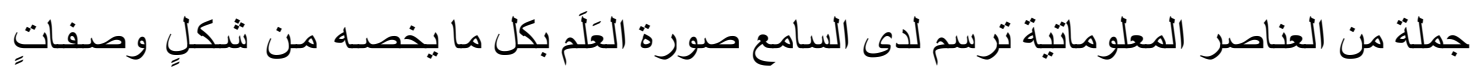

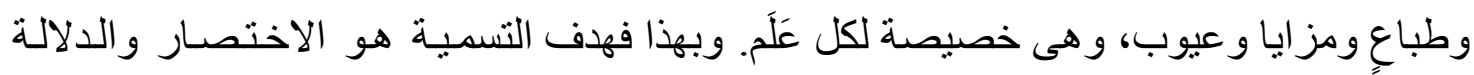

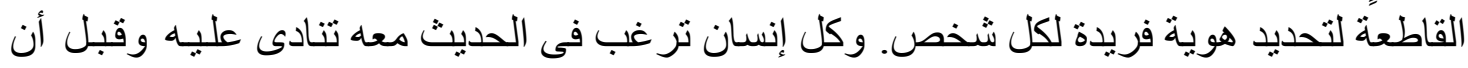
تنادى عليه تعرف اسمه.

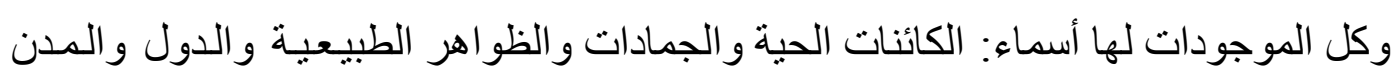

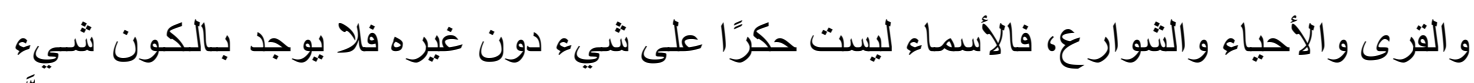

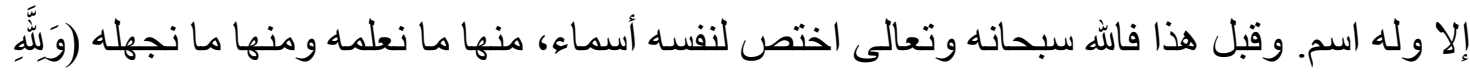

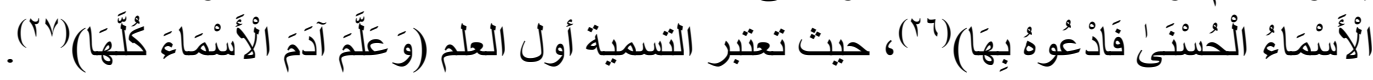

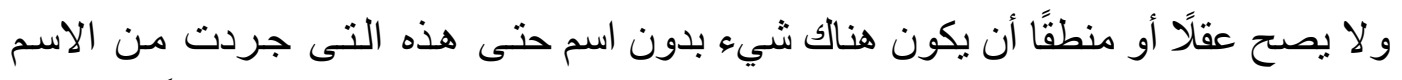

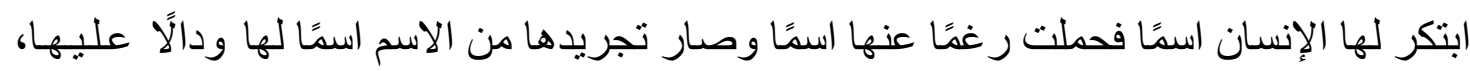

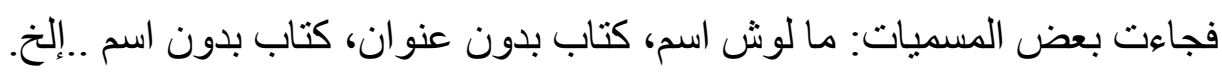

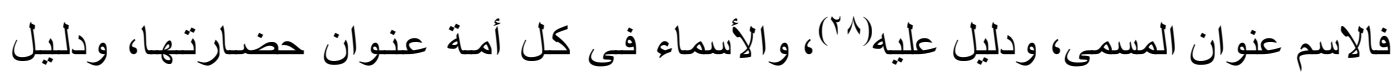

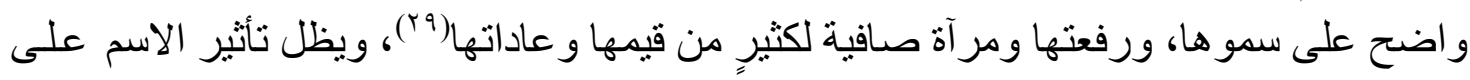

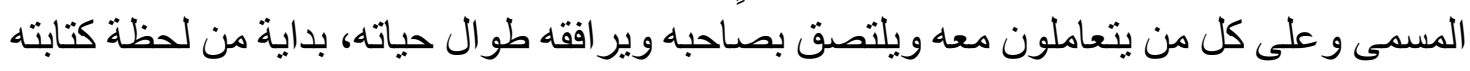

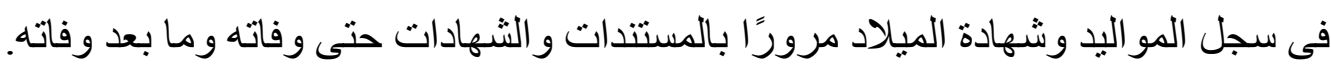

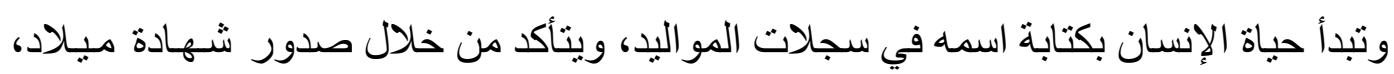

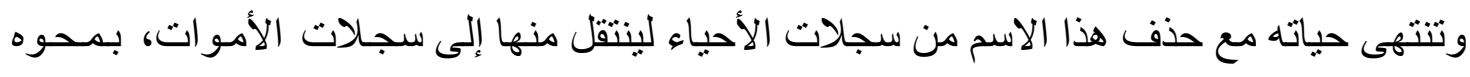
من الأولى وكتابته في الثانية فتصبح له شهادة وفاة، وبمجرد وفاته يُجرَّد من اسمه فينـادى عليه لأليه 


$$
\text { بالجثة والميت والمرحوم، فالاسم هو أحد خصائص الأحياء. }
$$

وتشكل الأسماء العربية للأشخاص جزءًا لا بتجزأ من الثواء الثقافة العربية، فطريقة تركيبها

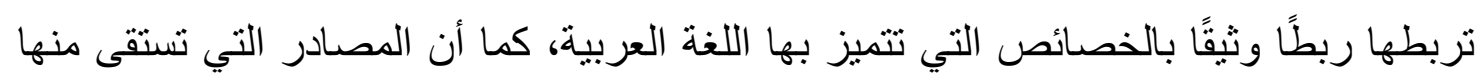

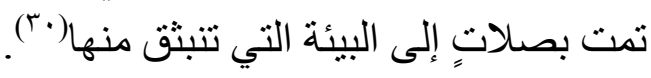

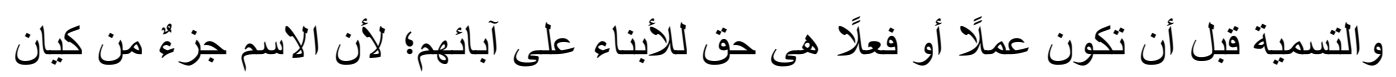

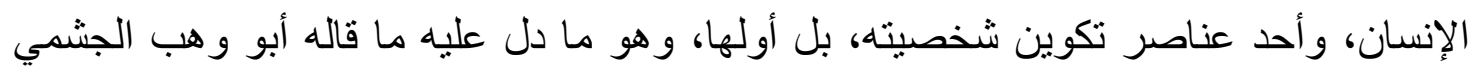

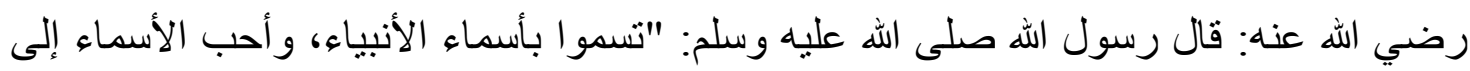

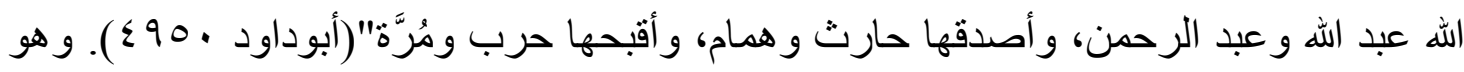

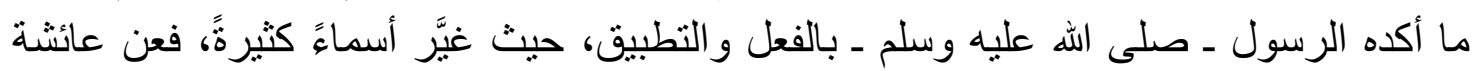
رضي الله عنها: "أن رسول الله ـ صلى الله عليه وسلم ـ كان يغير الاسم القبيح" أخرجه الترمذي ولئ

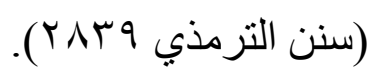

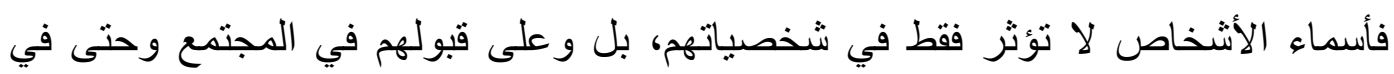

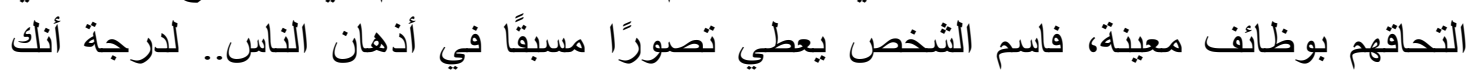

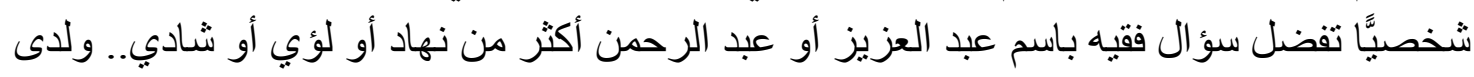

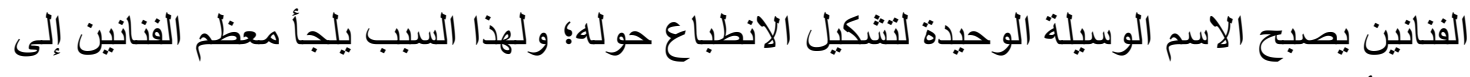
تغيير أسمائهم؛ طمعًا في الثهرة والوصول، وهو ما جعل شيروت فهمي تغير اسمها إلى ليلى طاهر، وتصبح (جانيت فغالي) صباح، وتصبح (عفاف محمد) ماجدة، وتصبح (فاطمة أحمد)

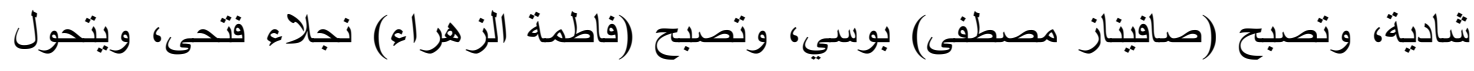

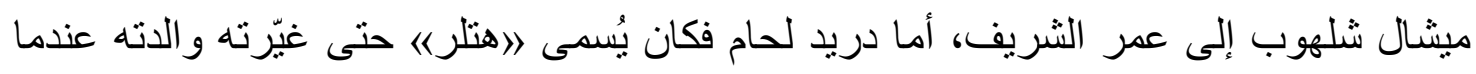

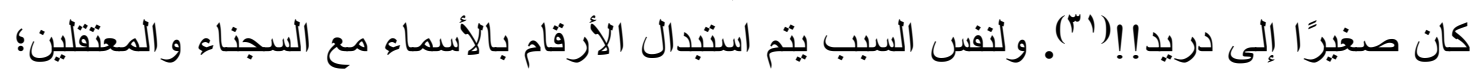

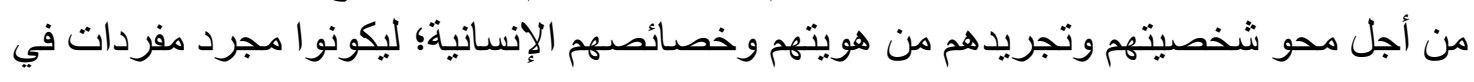
المجموع حتى يسهل فرض الطاعة العمياء عليهم. وقد تُستخدَم الأسماء للتعبير عن الحالة النفسية للوطن، وهو ما دفع لظهور أسماء مثل: هتلر وموسولينى، إيّان الحرب العالمية الثانية أطلقها المصريون على المواليد تعبيرًا عن شدة كر اهيتهم للاحتلال الإنجليزى عندما كانت جيوش الألمان على أبواب الإسكندرية، على الرغم من أنها

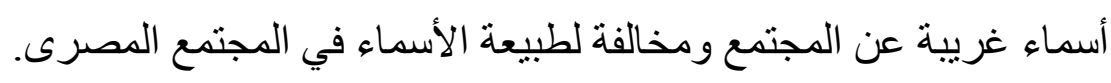

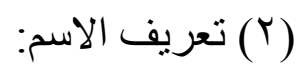
للاسم معنيان، معنى ضيق يُقصد به الاسم الثخصي، و المعنى الثاني يُقصد به اللقب أو اسم

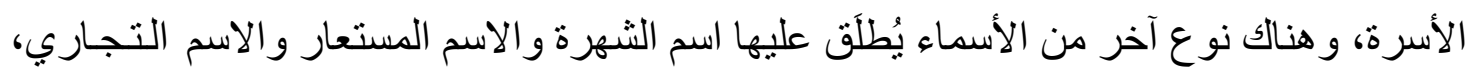
و هى ليست أسماء حقيقية. وقد أكد أهمية وقيمة ما يحظى به الاسم، الحماية التي منحها لله القانون 


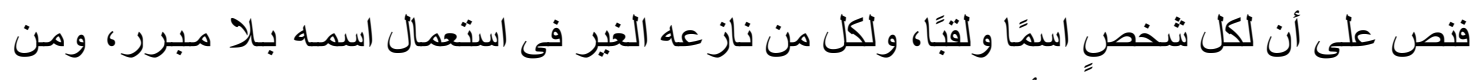

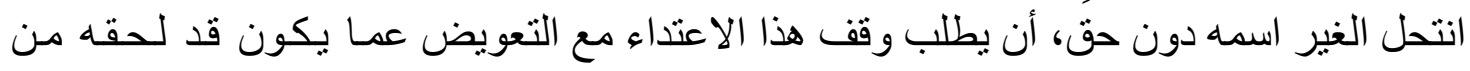

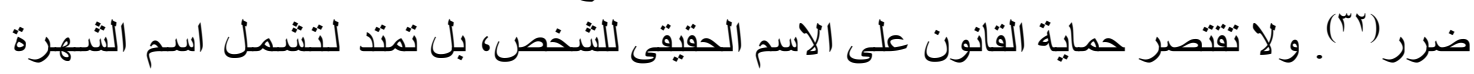

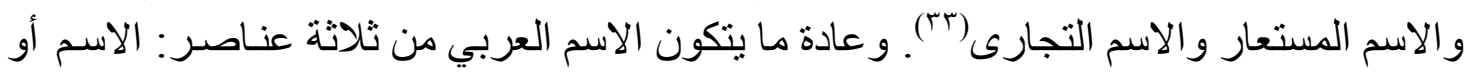
العلم، و الكنية أو الاسم المركب، و اللقب أو الاسم المستعار، ويُعد اللقب أكثر مقاطع الأسماء تعقيدًا

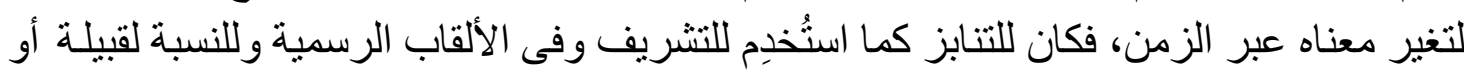

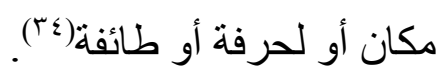

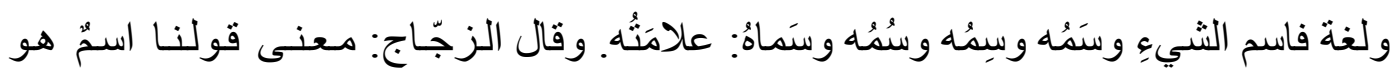

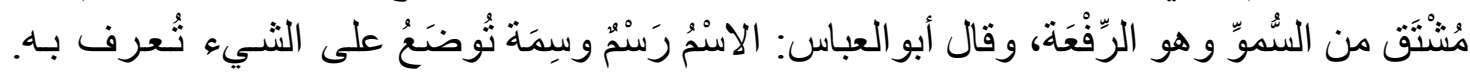

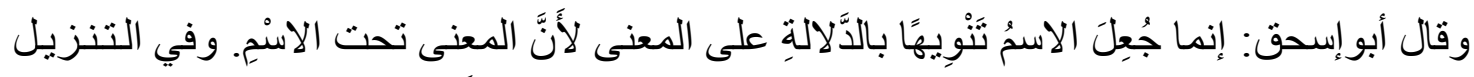

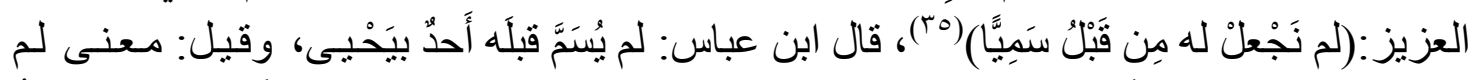

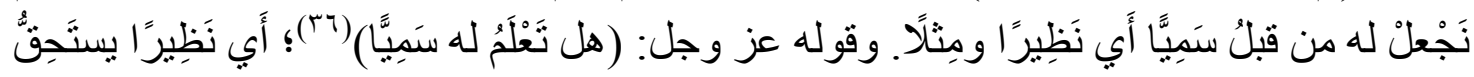

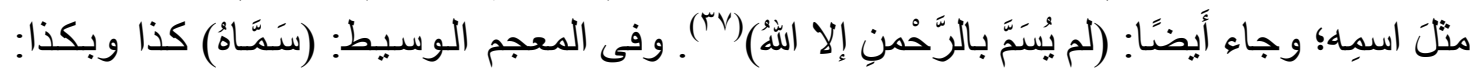

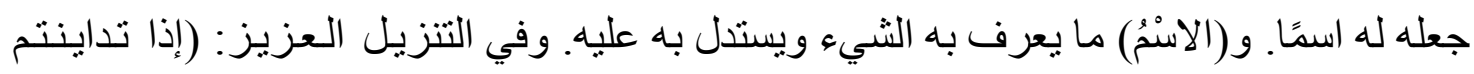

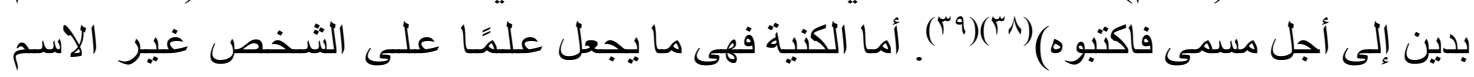

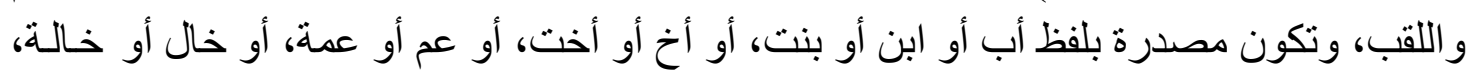

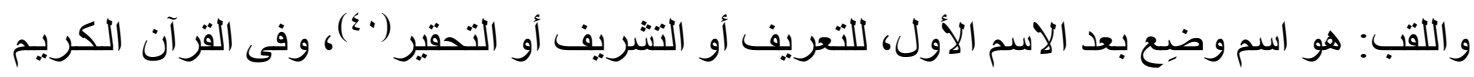

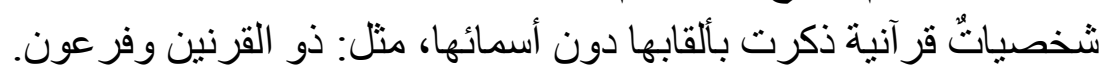

$$
\text { (T) أهمية الاسم و الاهتمام العربى به: }
$$

اهتم العرب قديمًا وحديثًا بالأسماء، وشو اهد التراث العربي الدالة على ذلك كثيرة، فحظيت التهاء

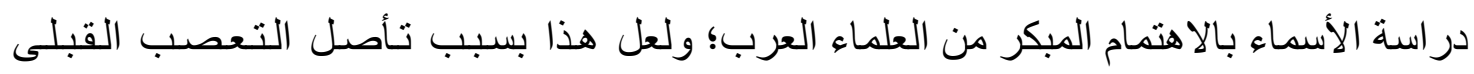

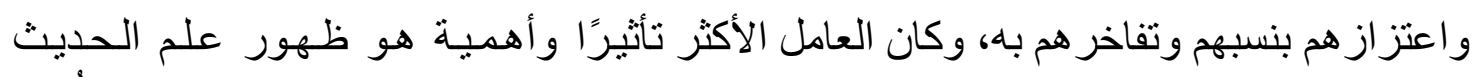

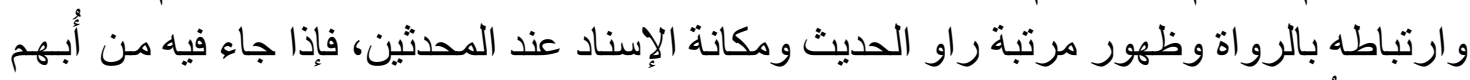

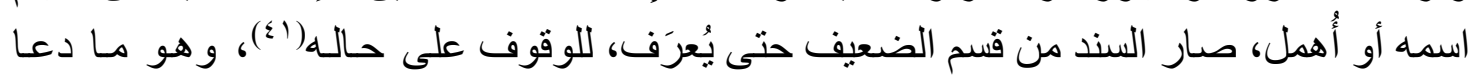

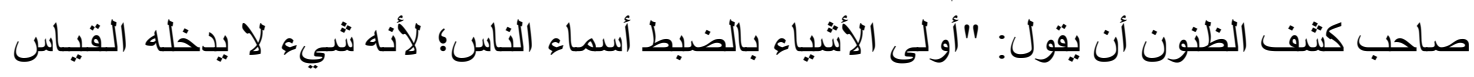
ولا قبله شيء يبل عليه و لا بعده"(r؟).

وكان نتيجة لهذا الاهتمام أن صنفو ا في الأسماء عشر ات الكتب التى درست الأعلام و الأسماء

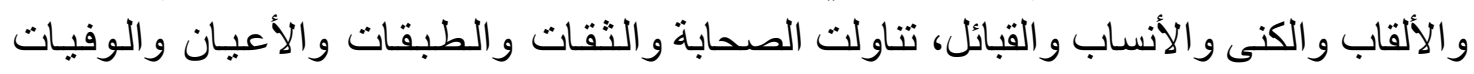

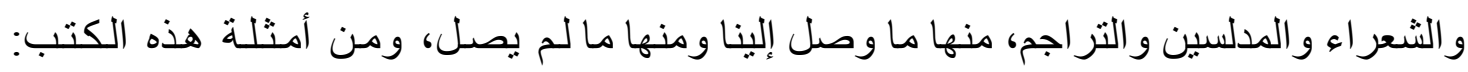

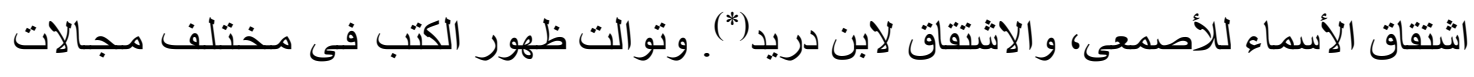


الأسماء، مثل: "طبقات الأسماء المفردة من الصحابة و التابعين و أصحاب الحديث"، و "المبهج في

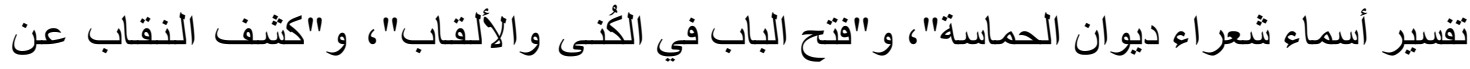

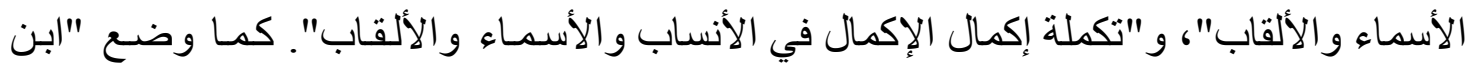

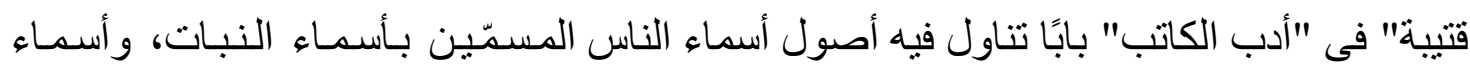

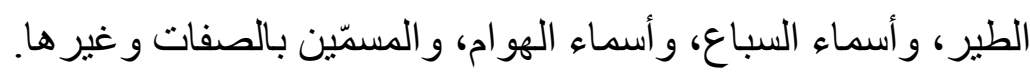
وحتى الأسماء المستعارة تمت در استها حديثًا كما فعل يوسف أسعد داغر فى كتاب "معجم

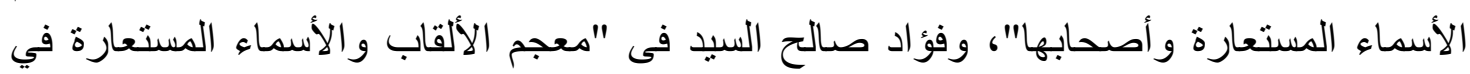
التاريخ العربي و الإسلامي".

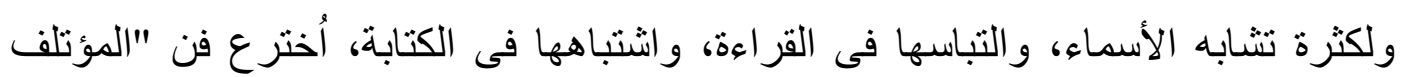
والمختلف" من فنون التاريخ المسجَّل و المدوَّن، فظهر أكثر من كتابٍ في هذا الميدان، منها:

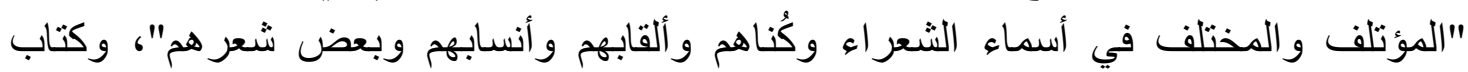

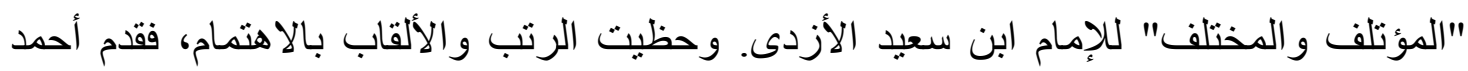

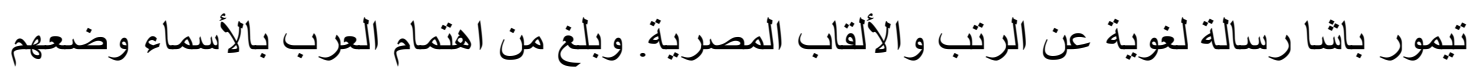

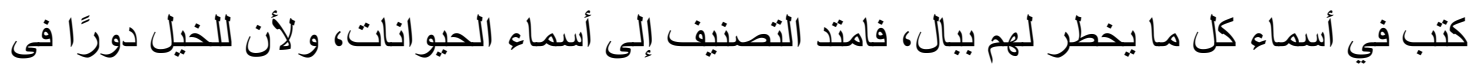

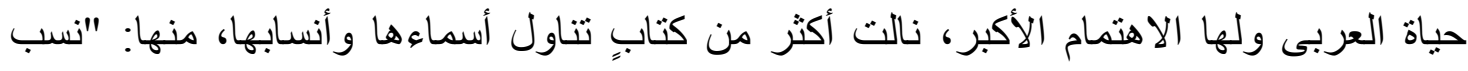
الخيل في الجاهلية والإسلام و أخبار ها"، و الخيل، وأسماء خيل العرب وفيل وفرسانها، و الحلبة في

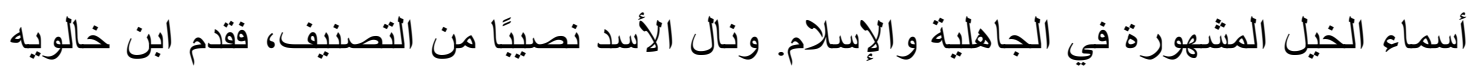

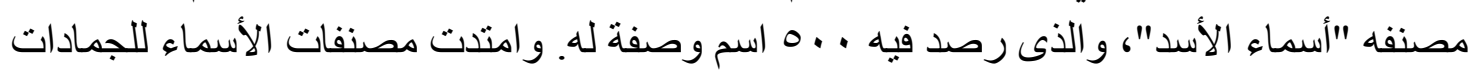

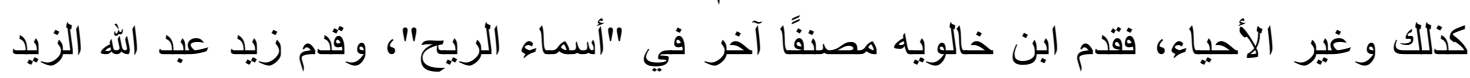

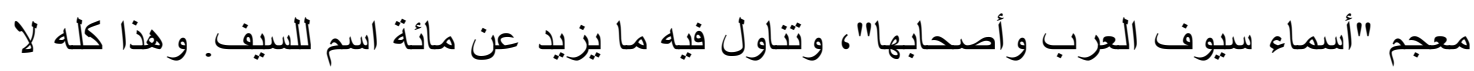
يمثل أو يرصد لكل ما كُتبب، بل هو مجرد غيضٍ من فيض فيض. علاقة الاسم بالمعلومات:

تُعد قضية المعلومات قضية اجتماعية فى المقام الأول وتعتبر اللغة أحد المكونات المهمة

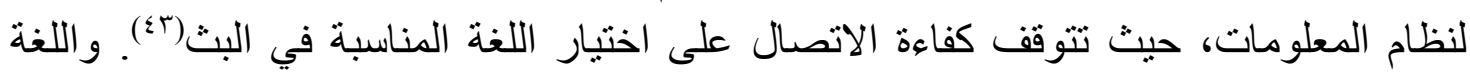

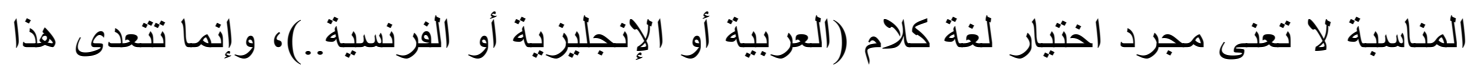

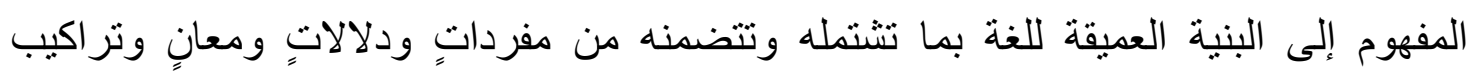

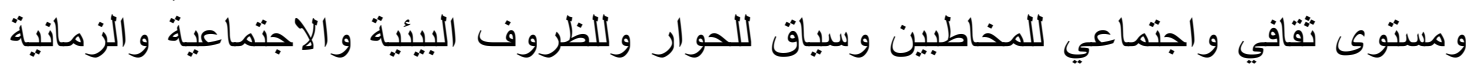

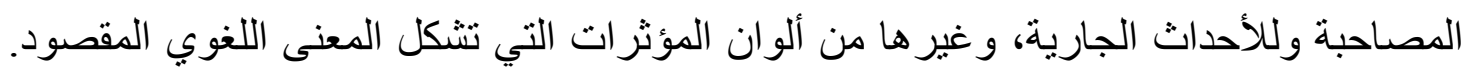

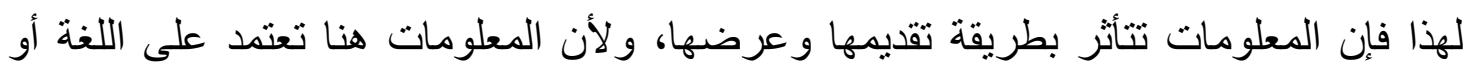

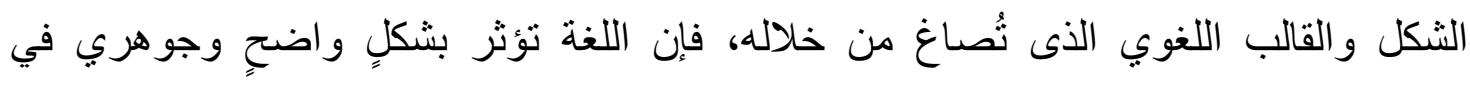




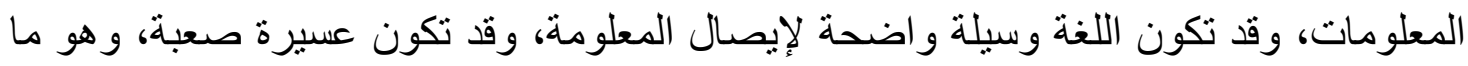

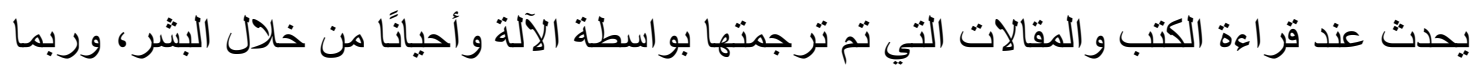
يكون الأصل الأجنبي أوضح وأبسط وأسهل بكثير؛ والسبب طريقة وأسلوب عرض وضن وتقديم وصباغة المعلومات في شكلها اللغوي.

وباعتبار الأسماء ظاهرة اجتماعية، فهي تتفاعل مع المجتمع فتتأثر به وتؤثر فيه، فتتأثز بكل

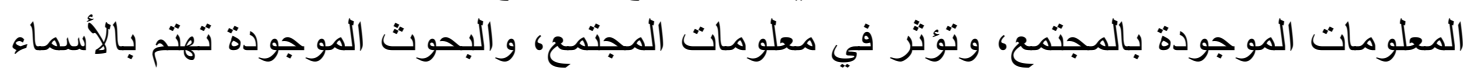

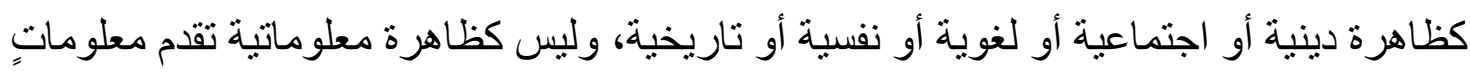
وتنثأ وتولد من معلومات، وهو يجمع في داخله وبين ثناياه خصائص معلوماتية للمجتمع الذى لثى

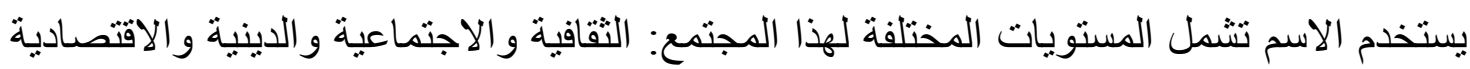

و العقائديبة.

الاسم في المجتمع العربى:

قديمًا كان للقابلة أو مسجل الصحة دور مهمٌّ في تسجيل الاسم واختياره، حيث كانت عملية

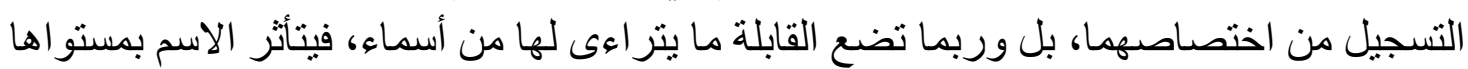
التعليمى فيدوَّن الاسم بصورة خاطئة أو هجاء غير صحيح، ويظل صناحب الهب الاسم بهذه السبة طو ال

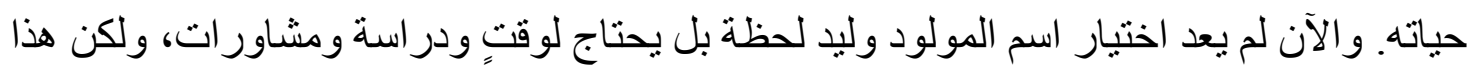

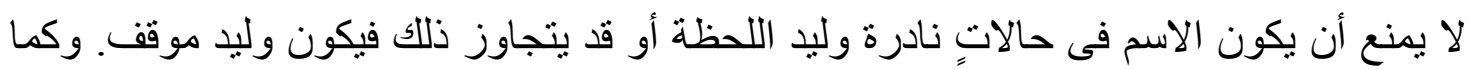
أن ميلاد الطفل يحتاج وفتًا ليتحول من نطفة لعلقة فمضغة فجنة فنين ثم وليد؛ فالأمر نفسه مع الاسم الذى يأتى اختياره من فكرة أو مجموعة أفكار، وقد يبدو اختيار اسم المولود فى ظاهره عملية بسيطة، إلا أنه فى جوهره هملية معقدة تتضمن أبعادًا فكرية و إبداعية تستغرق وقتنًا وجهدًا كبيرًا

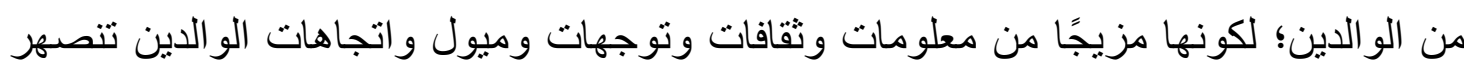

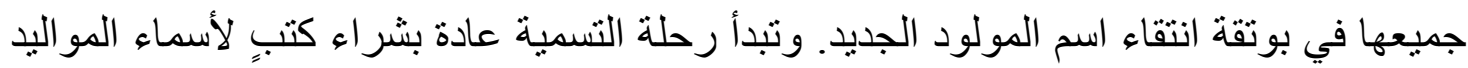
وتحديد معانيها أو بتسجيل كل الأسماء التى ير غبان فى الاختيار منها، وتبدأ بعد ذلك عملية الفرز

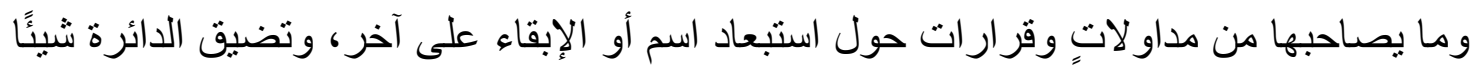

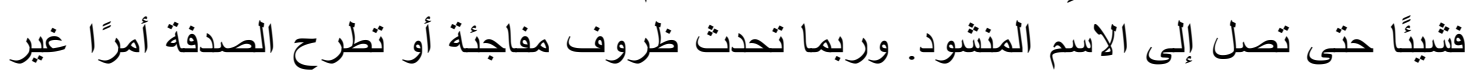

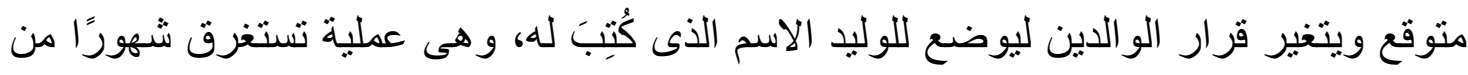

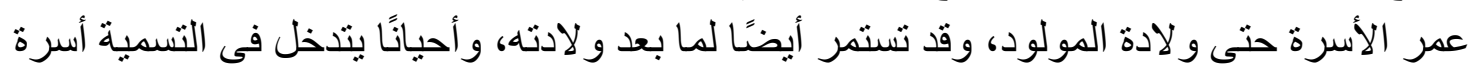
الزوج أو الزوجة، وقد يؤثر وجود الجد أو الجدة على قرار التسمية فيكون لهما دورٌ مؤثر فيها.

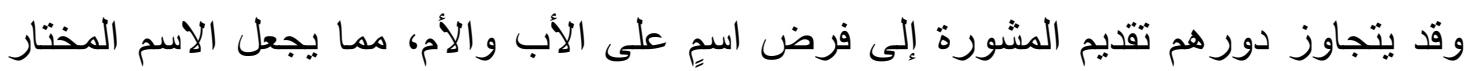

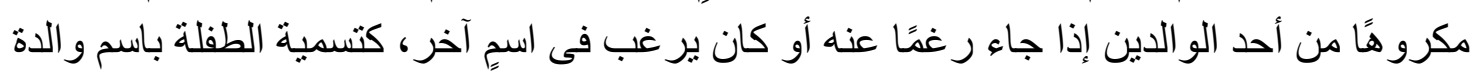

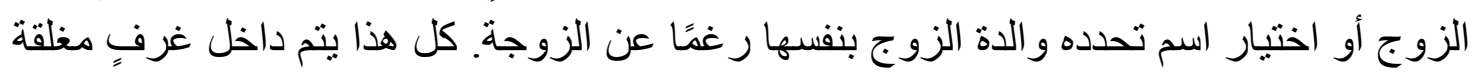


لا يعلم بها سوى الوالدين أو مَن شاركهما فى تسمية الوليد حتى يتم تسجيل المولود فى شهادة

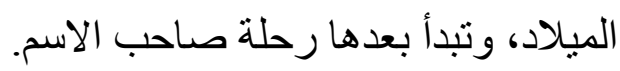

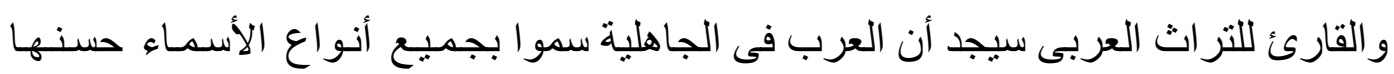

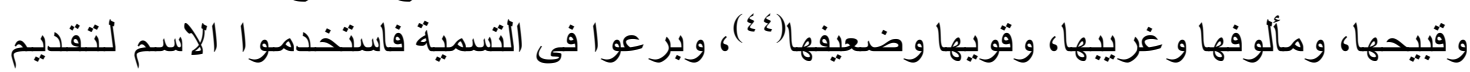

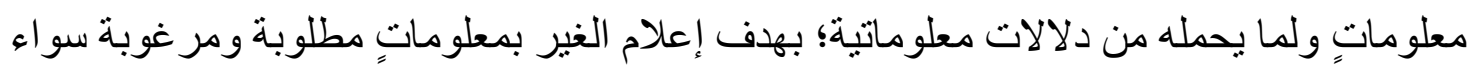

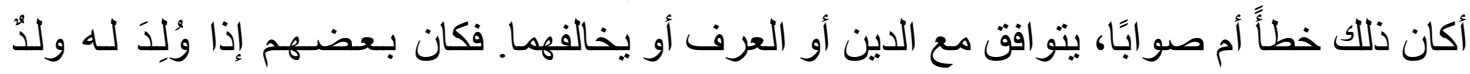

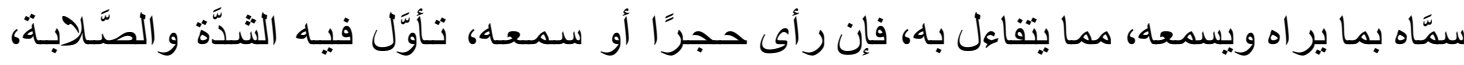

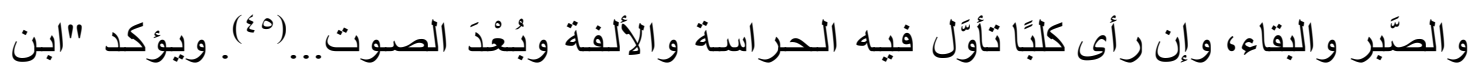

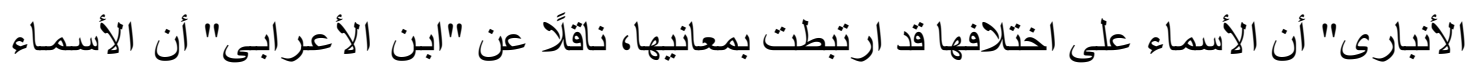

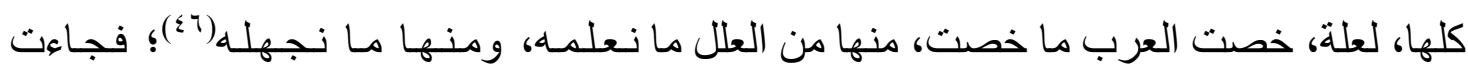

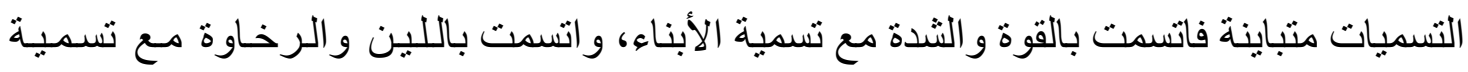

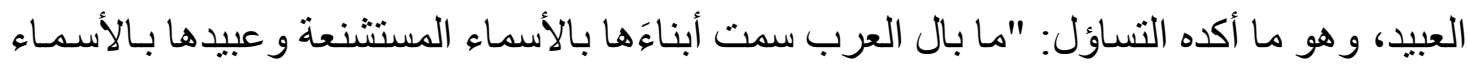

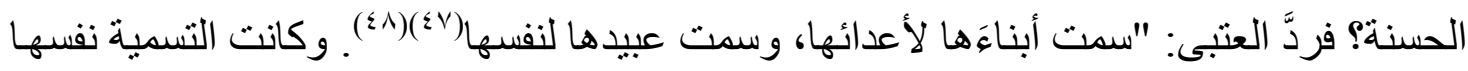

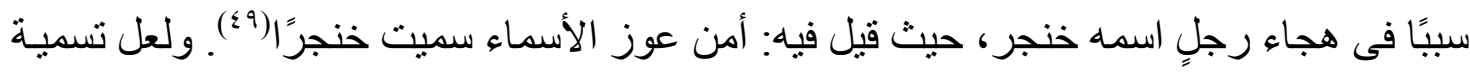

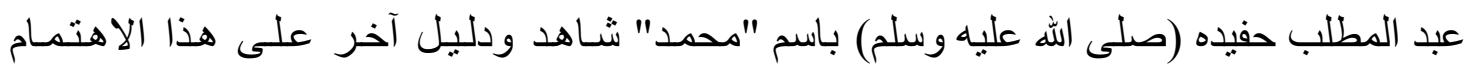

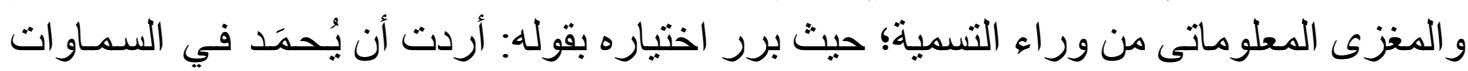

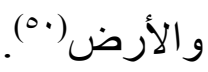

و على الرغم من أن اليهود عاثوا فترة طويلة فى بلاد العرب، فالعرب قبل الإسلام، لم

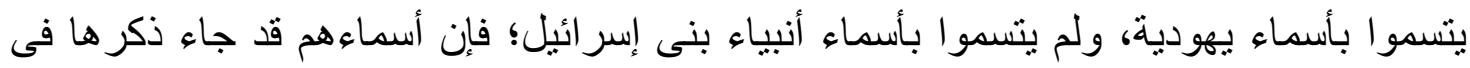

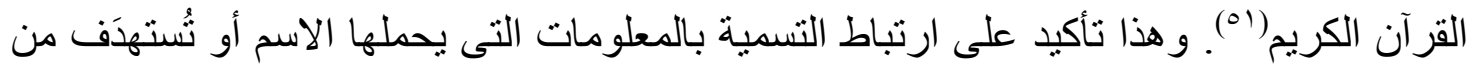
التسمية.

ثالثًا ــ الدراسة التطبيقية:

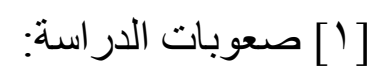

تعددت صعوبات حصر أسماء المصريين من ناحية العدد الضخم الذى تناولته الدراسة،

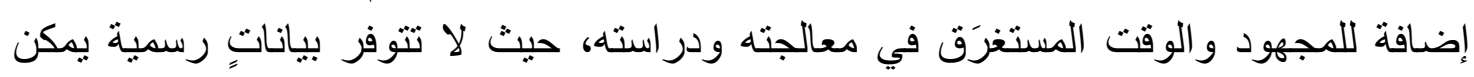

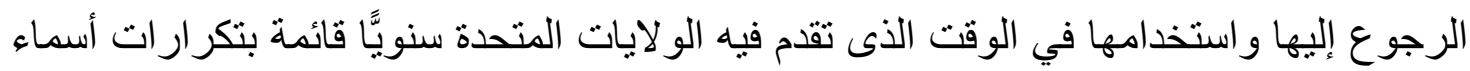
المو اليد مرتبة بالأعلى تكرارًا مع بيانٍ بعدد التكرارات وجنس المولود. وحماية للخصوصية يتم

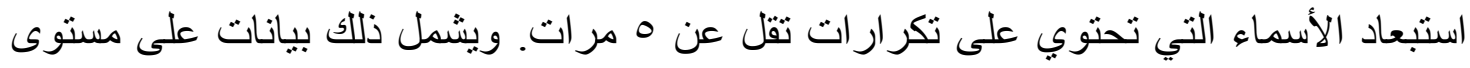

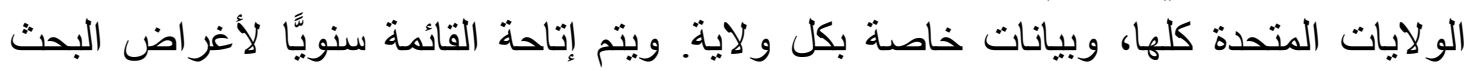

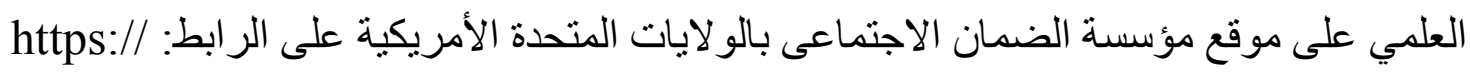


.www.ssa.gov/OACT/babynames/limits.html ويضاف إلى صعوبات الكم وجود أخطاء التسجيل فلم يمنع استخدام الحاسب في كتابة الأسماء من الوقوع في الأخطاء عند كتابة الأسماء رغم أن التسجيل يخص نتائج شهادات در اسية، و هو ما أكدته المو اقع الناشرة للنتيجة أنها "ليست مستند رسمي" لاحتمال وقوع الأو الخطأ بها. وقد توز عت الأخطاء على خمسة أشكال هي:

(1) المسافات: تعددت أخطاء استخدام المسافة كوضعها في غير أماكنها قبل الاسم أو بعده أو داخله، مما يقسم الاسم الواحد في المعالجة إلى اسمين أو يمنع من معالجته على النحو الصحيح.

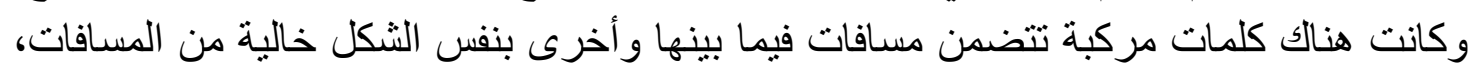
مما يجعل هنالك شكلين لكل اسم. أو عدم وجود مسافة مما جعل كل الحروف تتشابك لتشكل اسمًا

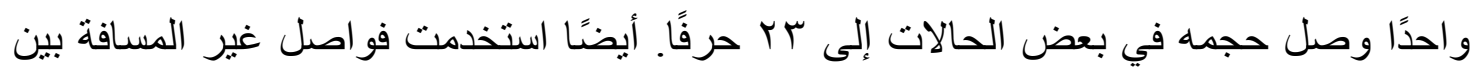
الأسماء، مما منع معالجة الاسم (تطلب الأمر استبدال هذه الفو اصل بالمسافة المانة).

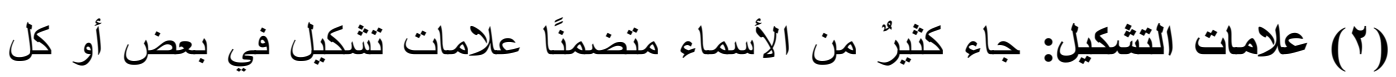
حروف الاسم، وخلت غالبية الأسماء من التشكيل، مما جعل هنالك أكثر من شكلٍ للاسم الو احد. (r) أخطاء الكتابة: ظهرت في حذف بعض الحروف، و استبدال حرفٍ مكان آخر ، واستبدال

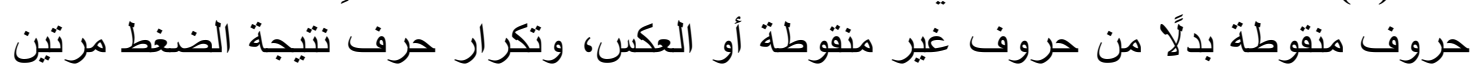
على نفس الزر، ونسيان كتابة حروف.

(ع) أخطاء اختلافات الكتابة (الاستخدام المتبادل): استخدام الهاء و التاء المربوطة بالتبادل،

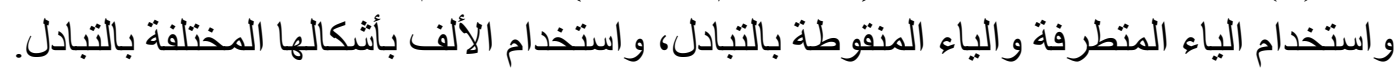

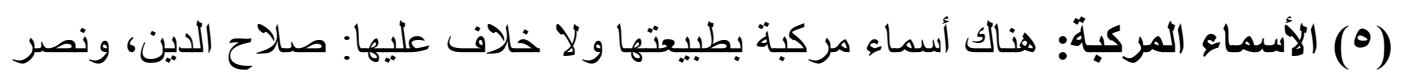
الدين، و أبو الوفا... إلخ، و هنالك أسماء مركبة لا بمكن الوقوف على ماهيتهاء و التأكيد على أن الاسم

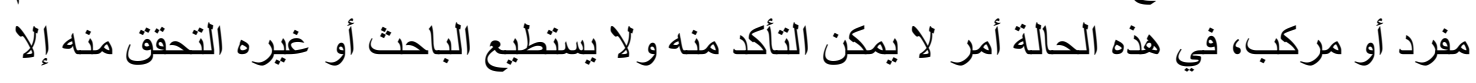

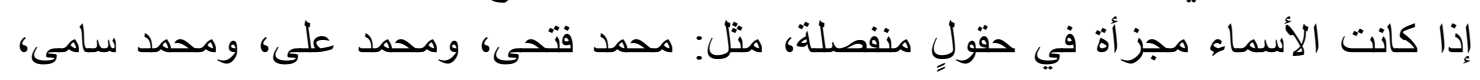

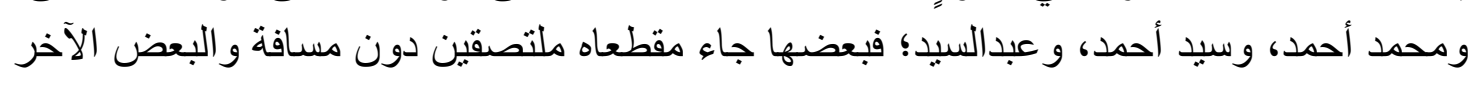
تخللته مسافة؛ لذا تم استبعاد هذه الفئة من الدراسة لعدم وجود وسيلة ضابطة تقطي فئع بحقيقتها، باستثناء ما كُتب منها بين علامتى تتصيص في أصل النتيجة، و اعتبرت اسمين منفصلين. ] [ [ ] خطو ات الدر اسة:

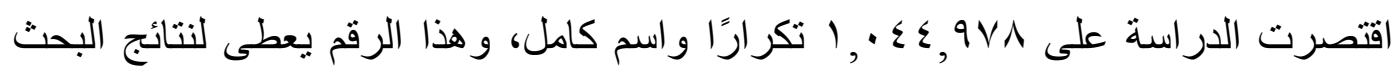

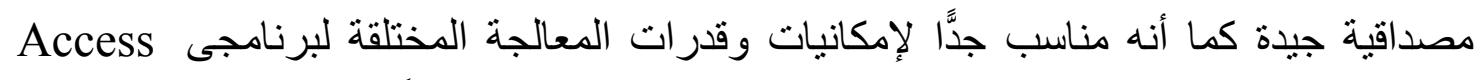

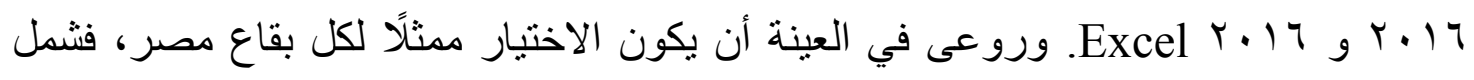


مجمو عة محافظات مختلفة. وتم استبعاد طلاب المنازل باعتبار أنهم يخرجون عن إطار العينة المحددة، حيث كانت البيانات ببعض ملفات النتائج تشير إلى أن البعض كانو أبنا من طلاب المنازل. بدأت الدر اسة بإعداد قاعدة بيانات بالأسماء، ثم تجميع كل الأسماء التى تم الحصول عليها

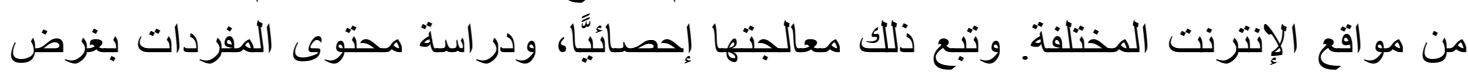

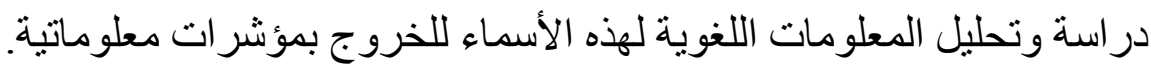

استخدمت الدر اسة أكثر من طريقة وأسلوب لتحديد نوع صاحب الاسم، فبدأت باستخدام دوال

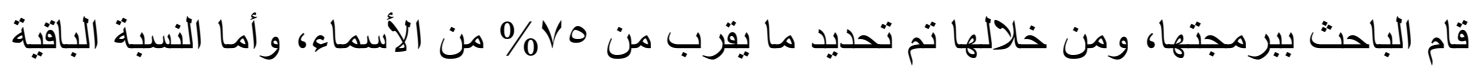

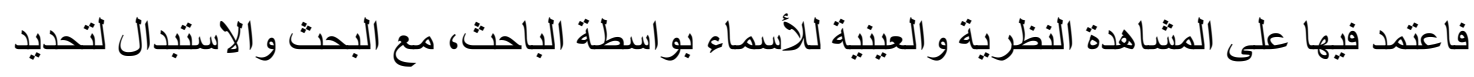
نوع الاسم.

\section{مرث المعالجة بالخطوات التالية:}

[1] استبعاد أي بياناتٍ لا تخص الدراسة من ملفات نتائج الطلاب بفصل أسماء الطلاب

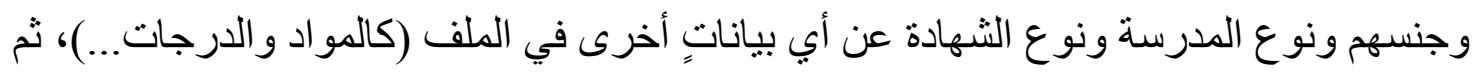

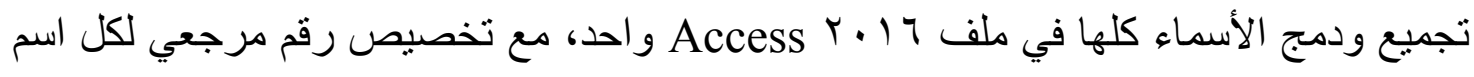
للمر اجعة.

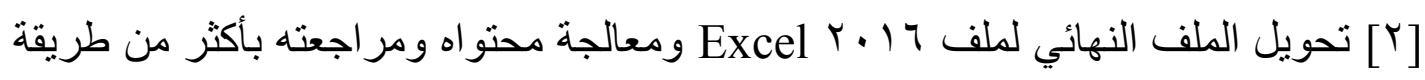
و أسلوب؛ للوصول بـ تهوئ إلى أكبر قدر من الدقة و الصحة. [ץ][ معالجة الاسم بالكامل هو محور المعالجة (الطالب، الوالد، الجد، اللقب): تجزئة الاسم الكامل إلى مفرداته، من خلال المسافة باعتبار ها الفاصل الطبيعى بين الأسماء المفردة (الأحادية)

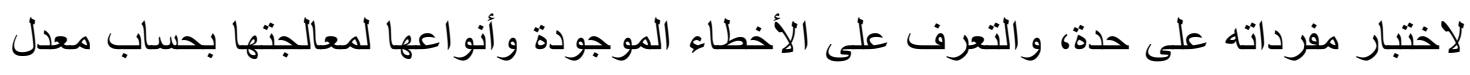
التكر ار ات للأسماء الناتجة، و التعرف دانه على والعرف الصو اب منها و الخطأ.

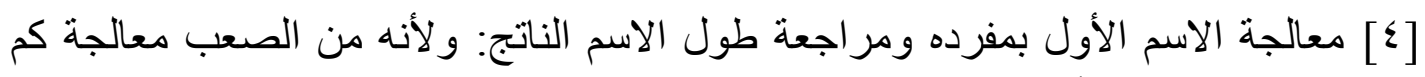

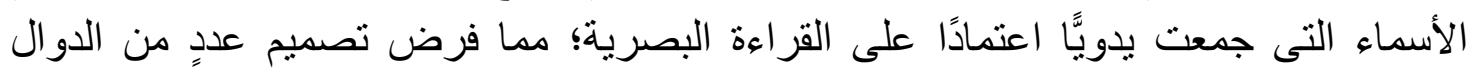
البرمجية في برنامج Excel؛ لتساعد على سرعة إنجاز ومعالجة هذ العدد الضخم من الأسماء،

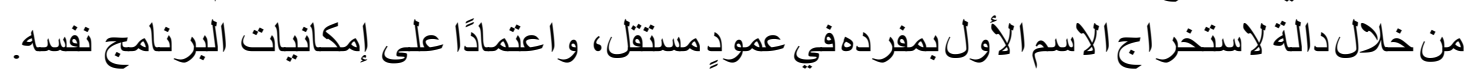

\section{خطوات المعالجة وما تم تتفيذه بالفعل:}

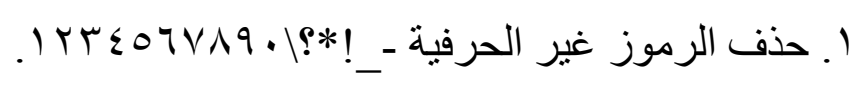

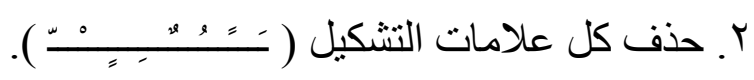
ז. حذف المسافات قبل الاسم الأول أو بعد الاسم الأخير أو داخل الاسم الواحد (فصل الأسماء 
ع. ضبط و إعادة تركيب الأسماء التي تخللتها مسافات.

•. توحيد شكل الألف أإآ (استبدال الألف المهموزة لتكون ألف بدون همزة لتوحيد الأسماء). 7. مر اجعة الحروف المتتالية بتكرار (ال، بب، حح، جج،... ).

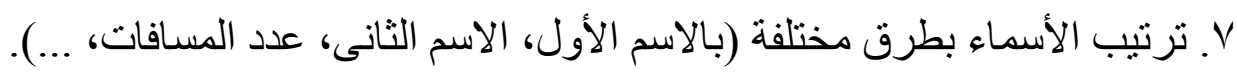

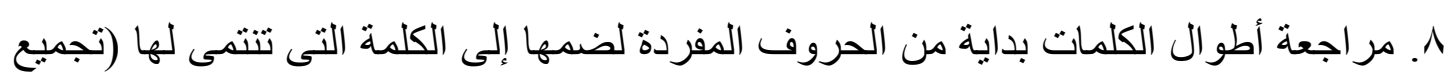
الاسم الذى فصلته المسافات)، ومراجعة باقى أطوال الأسماء وتصحيح الخطأ منها (الأسماء

و اضحة الخطأ).

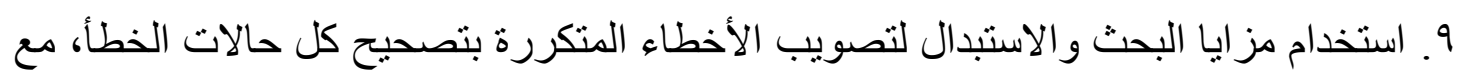
ترك أصل الاسم كما هو ليكون هنالك صورتان: صورة أصلية (خطأ أو صواب) وصورة بلئية مصححة؛ للمقارنة بين الصورتين و الاختلافات بينهما.

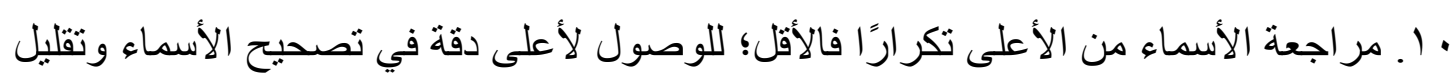

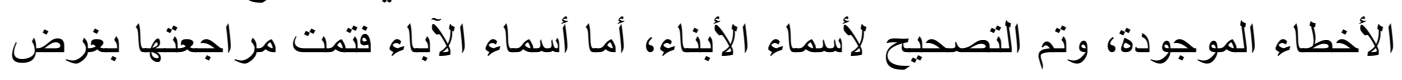

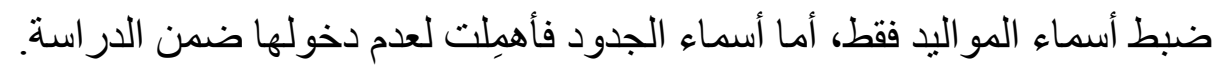
11 ا لـ يتمكن الباحث من الوقوف على الاسم الصحيح لبعض الأسماء فتركت الأسماء كما هي.

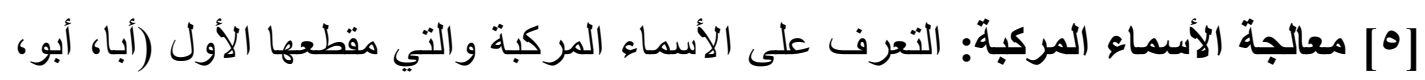

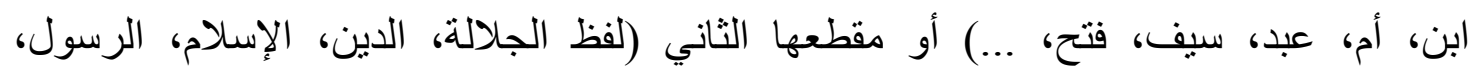

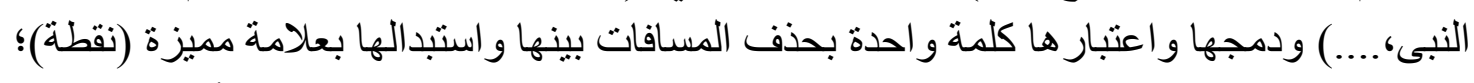
حتى يتم معالجتها ككلمة واحدة متحدة المقاطع ومر اجعة ما تم معالجته منها؛ للتأكد من صحة ودة المعالجة.

[7] معالجة نوع وجنس المولود: استخدمت المعلومات المتاحة في بعض ملفات النتائج، مثل: نوع الطالب (ذكر، أنثى)، أو نوع المدرسة ابتدائية (غالبًا مشتركة ذكور و وإناث)، و وإعدادية (غالبًا الذكور منفصلين عن الإناث)، ويظهر هذا من نوعها: بنين وبنات، ونادرًا ما تكون مشتركة.

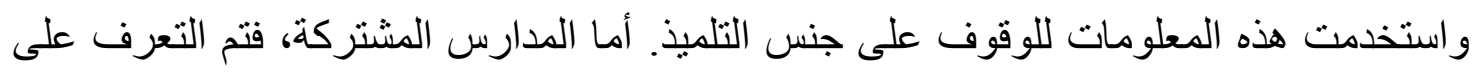
جنس الطالب باستخدام دوال تحدد نوع الاسم، اعتمادًا على أكثر الأسماء شهرة للذكور وألى والإناث بقر اعة الاسم الأول لتحديد نوع وجنس صاحبه (ذكر /أنثى). و الباقى تمت معالجته بالعين المجردة.

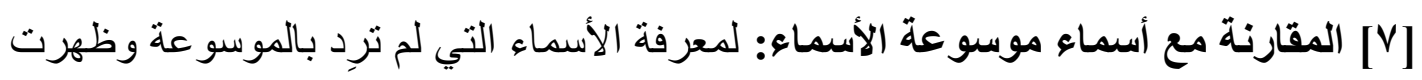

بعدها.

[^] المعالجة النوعية: تم الاحتفاظ بالاسم الكامل للمولود مع تسجيل البيانات النوعية التي

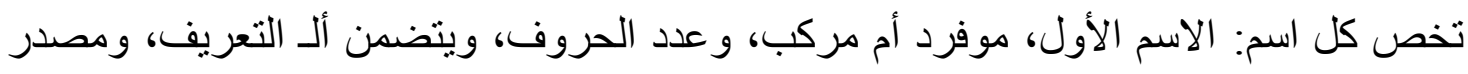
و أصل الاسم، ومعنى وتصنيف الاسم، و الجذر إذا كان موجودًا، و الصيغة، و عربى أم دخيل. 


\section{رابعًا نتائج الاراسة:}

الاسم جزء من الحياة، ولا يوجد موجود إلا وله اسم: إنسان، حيوان، جماد. ولاسم قلاسمة قيمة

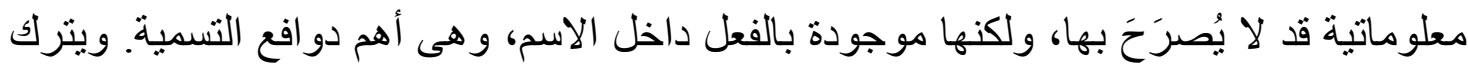

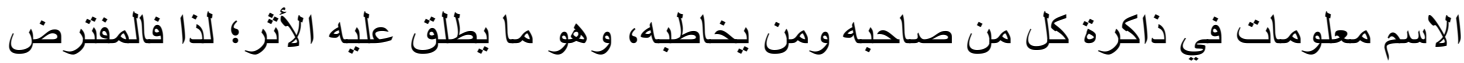

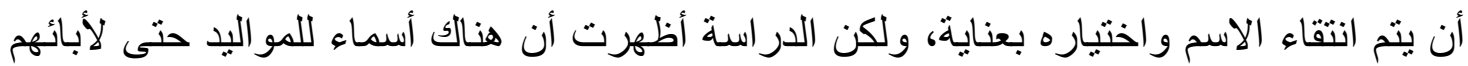

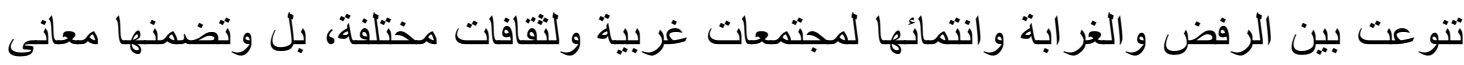

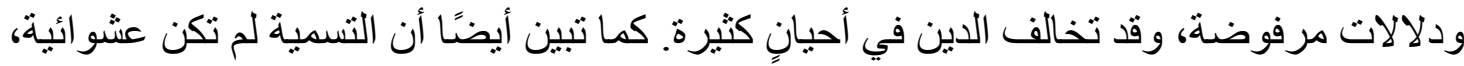

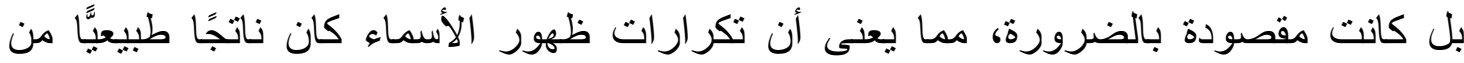

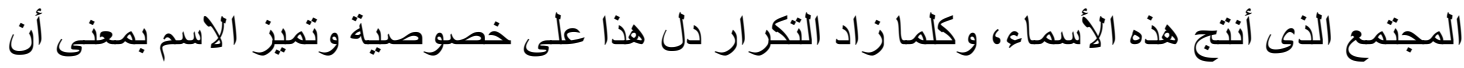

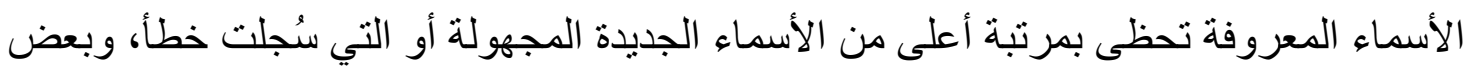

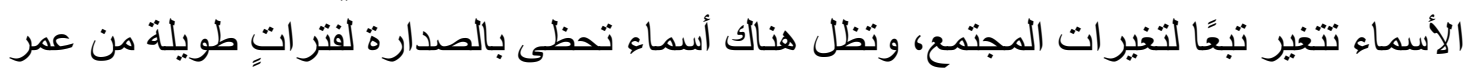

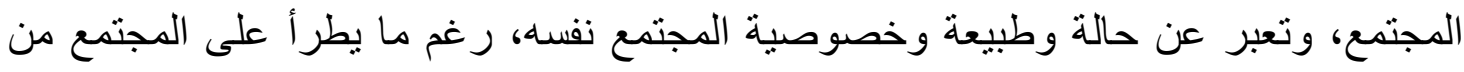

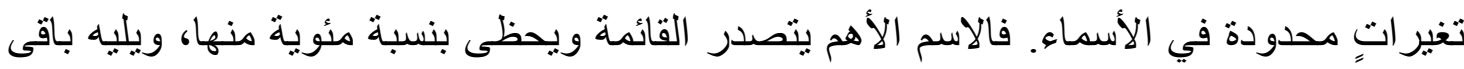

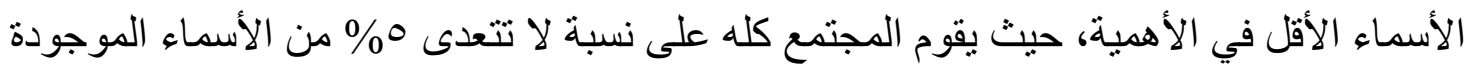

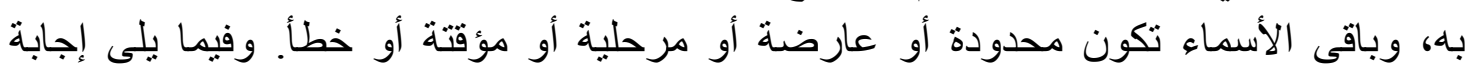

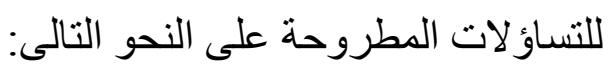

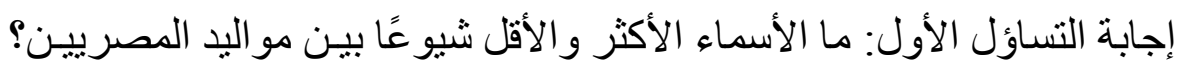

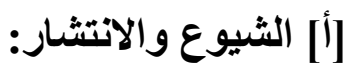

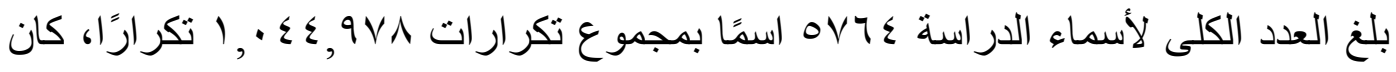

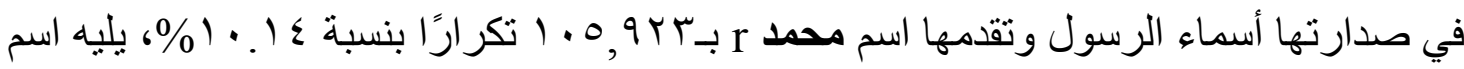

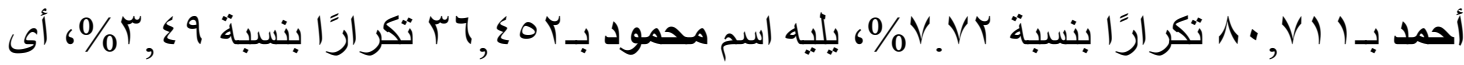

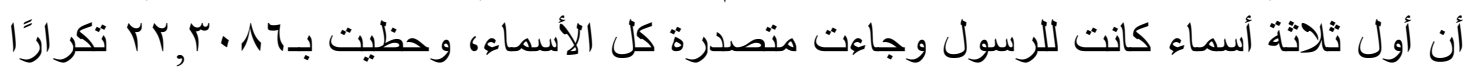

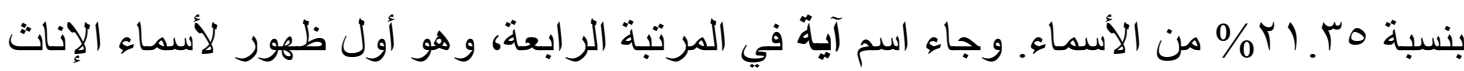

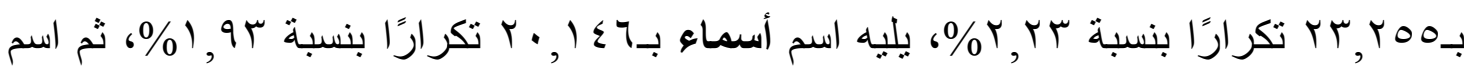

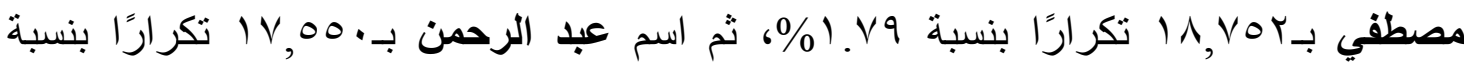

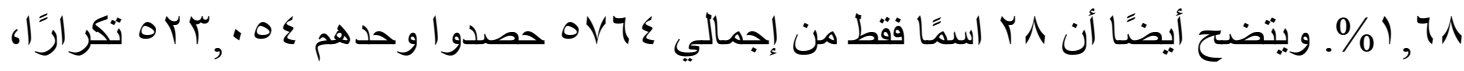

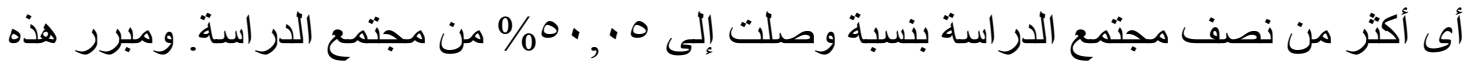

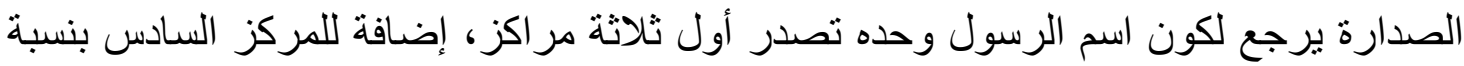

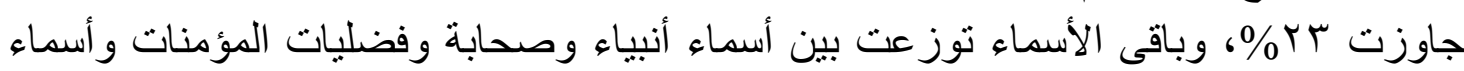

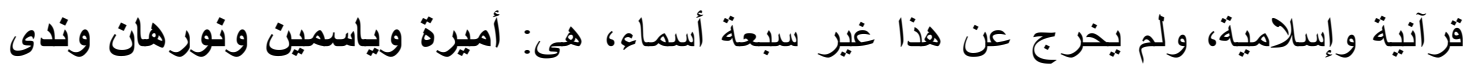

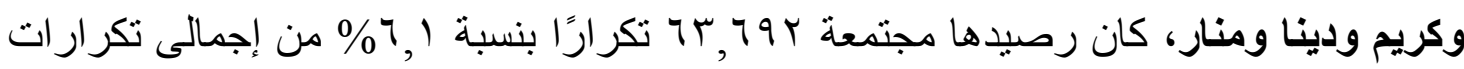




\section{مجتمع الدر اسة، و هى أسماء تجمع بين التراث و الحداثة جدول رقم ( ).}

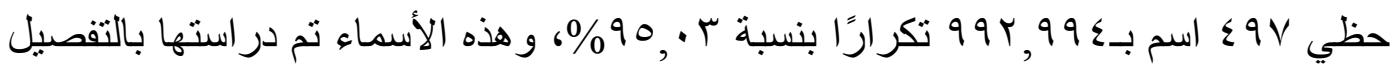

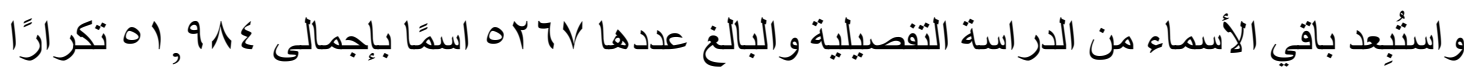

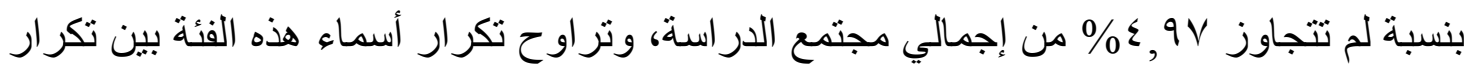
وحيد وحتى •ع أنكرارًا.

و اتضح من الدر اسة ظهور أسماء جديدة، وزيادة في استخدام أسماء دون أخرى، و انحسار

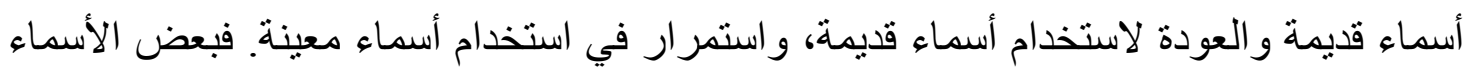
كانت منتشرة في فترة ما، وكانت كثيرة في اسم الأب والجد، وانحسرت بصورة واضحة وأرة في أسماء الدراسة، ومنها أسماء: فاروق وعبدالناصر وناصر، فكانت تكرارات فئات فاروق في الآباء

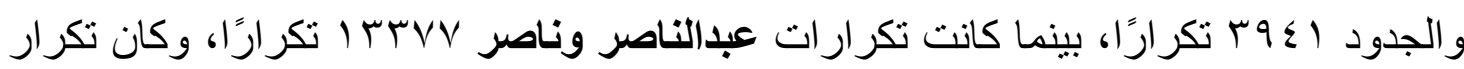

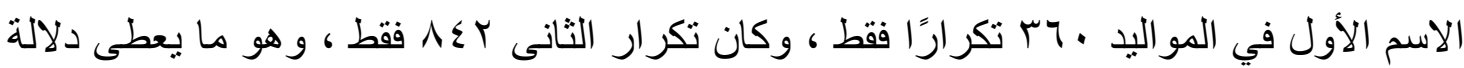
على أن السياسة ترمى بظلالها على اختيار الاسم. جدول رقم (1) جدول الثيوع والانتشار

\begin{tabular}{|c|c|c|c|c|c|c|c|c|c|}
\hline$\%$ & التزراكمى & $\%$ & ألتكزال & الاسم & $\%$ & ألتراكيى & $\%$ & ألتكزلا & الاسم \\
\hline 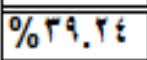 & $\$ 1 \ldots 1 T$ & $\% 1 . .7$ & 1.7Tt & ياسنمين & $\% 1 . .1 t$ & $1.09 \pi T$ & $\% 1+.1 t$ & $1.097 T$ & محد \\
\hline$\%$ क +.TT & $\leqslant T+\leqslant 0$ & $\% 1 .+\cdots$ & $1+t \pi T$ & إبزاكيخ & $\%$ IV.AT & 1147Tt & \%V.VY & $\overline{A . V 11}$ & (1) \\
\hline$\% \div 1 . T$ & $\leqslant T+\Lambda \leqslant T$ & $\% 1 .+\cdots$ & $1+t+1$ & هزير & $\%$ \% & $\mid \pi T+17$ & $\%$ \% & Tritor & محهو \\
\hline$\% \div .11$ & $t 5+119$ & $\% \cdot .90$ & 9979 & علىي & \% TT.OV & $T \leq 7 T \leq 1$ & \% \%.TT & TTYOO & إية \\
\hline$\%$ \%:T.1T & $\$ 0.0 \mathrm{NT}$ & $\% \cdot .97$ & 9V7T & 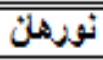 & $\%$ ro.0. & $\overline{T 71 \leqslant A V}$ & $\%$ \%!.9T & $7+1 \leq 7$ & أسماء \\
\hline$\%: \div .+T$ & $4 \div, 11 t$ & $\% \cdot .91$ & 90Tा & نائي & \% YV.T. & F10?Tद & $\% ! .19$ & INVOr & هصبطفي \\
\hline$\%: \leq .97$ & $5 \div 9 \div 0 \leqslant$ & $\% \cdot .19$ & 9T: & سأرة & $\% \curlyvee \wedge .9 \Lambda$ & T+TVAq & $\% ! .7 k$ & 1800. & عبألرحن \\
\hline$\% \div 0 . \wedge+$ & हVATाT & $\% \cdot . \wedge \Lambda$ & $917 \%$ & يوسبف & $\%$ \% . . & 179419 & $\%$ \%!.T & 1795. & إسزاءs \\
\hline$\% \div 4.01$ & ¿ATVYO & $\% \cdot . V \wedge$ & 1109 & كزيد & $\%$ \%T.19 & TTITIT & $\% 1.09$ & 171t: & إيمان \\
\hline$\% \div Y . T 1$ & 595919 & $\% \cdot . V \wedge$ & Alt: & هلجز & $\%$ TT.01 & TOQT.V & \%!.T & | $17 \lambda \leq t$ & فاطية \\
\hline$\%: \Lambda .+\Lambda$ & $0,7 \div+0$ & $\% \cdot . V T$ & $V \leqslant \Lambda i$ & ثمز & $\%$ \%t.VA & TiT:Ti & $\%$ \%!.TV & $17 r 19$ & شئيائر \\
\hline$\% \div \Lambda . V_{0}$ & $0.9 t \leq t$ & $\% \cdot . \mathrm{TV}$ & 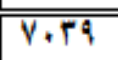 & لينا & $\%$ \% & TVIT:4 & \%!.TT & ITAT. & إسلالم \\
\hline 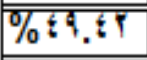 & $017 T$ T & $\% \cdot .74$ & 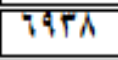 & هنّز & $\%$ \%V.IT & TAVAVT & $\% ! .11$ & IIIV & الهيزة" \\
\hline$\% 0 \cdot .+0$ & $0 \pi+0 t$ & $\% \cdot .7 t$ & IVVT & لئئ & \% \% TA.TT & FQ9TVA & $\% 1.1$. & 110.0 & 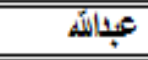 \\
\hline
\end{tabular}




\section{[ب] الندرة والغزابة:}

في مقابل الثهرة تأتى الندرة، حيث حظيت كثير من الأسماء بالندرة الملحوظة، ولم يتجاوز

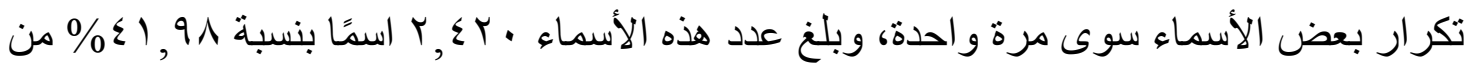

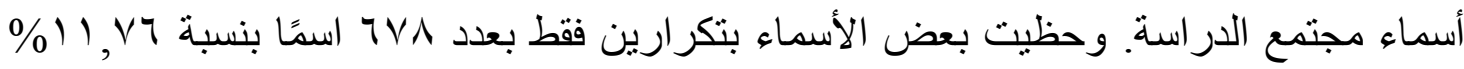
من أسماء مجتمع الدراسة، وهو ما يظهره جدول رقم (Y). وكانت الندرة تزيد من جهة الأسماء المجهولة والمستوردة والجديدة وغير المعلومة، أما الانتشار والثيوع فكان من جهة الأسماء وهاء المعلومة و الأصيلة و القديمة.

وشملت الأسماء النادرة والغريبة عن المجتمع المصرى أسماء مثل: أحمد بن بيلا، وغاندى، قد تكون التسمية بسبب دور صاحب الاسم أو كأسلوب للرفض أو التأييد أو الحب، وقد يتم استير ادها وجلبها من أي مكانٍ دون وعى أو فهرٍ لما تعنيه أو تتضمنه من معنى أو ثقافة.

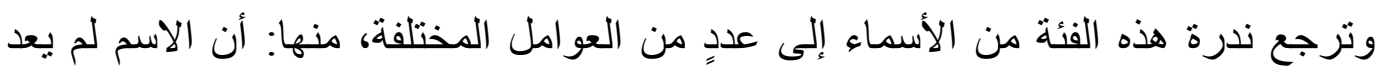

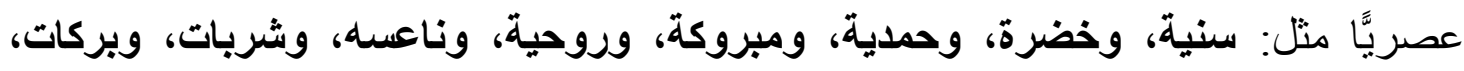

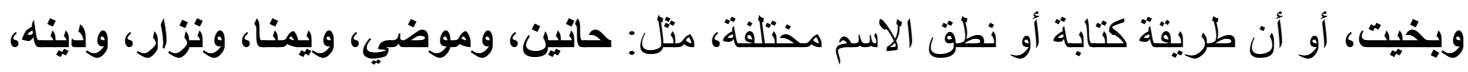
وسوها، وظهرة، وصارة، أو أن الاسم جديد وغير مألوف، مثل: حامده، وحاسم، وعامره، وعالميه، وحساب، أو لكون الاسم غير مصري وتم استير اده من إحدى الدول العربية، مثل:

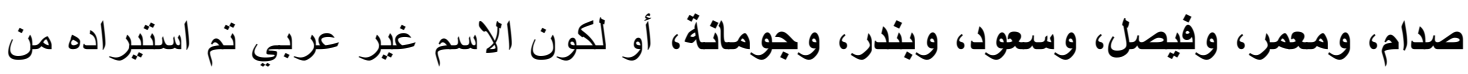

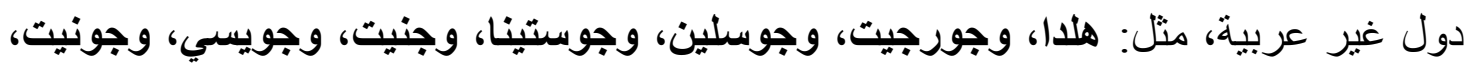

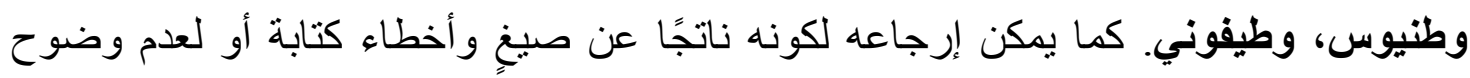

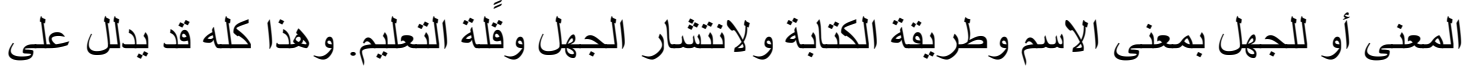

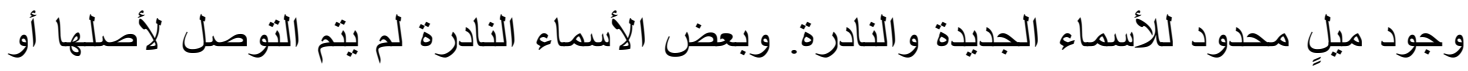

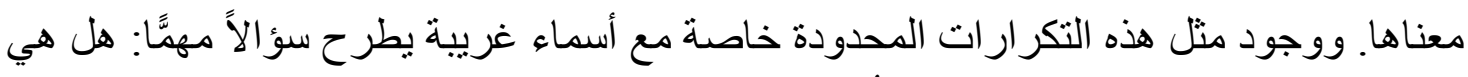

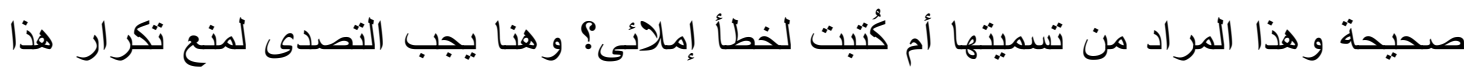

و أظهرت الدر اسـة أيضًا اختفاء أخطاء كانت موجودة في أسماء الجدود و الآباء، مثل: طارء وطارئ لاسم طارق، وشضيض لاسم شديد، و عبدالثبور و عبدالصابور لاسم عبدالصبور ، وطاها

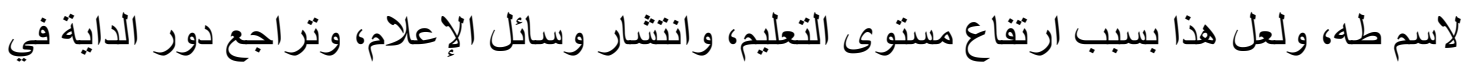


جدول رقم (r) جدول الندرة

\begin{tabular}{|c|c|c|c|c|c|}
\hline عدد الأسماء & التكرار & عدد الأسماء & التكرار & عدد الأسماء & التكرار \\
\hline$\leqslant 1$ & 10 & 91 & $\Lambda$ & $r \leqslant Y$. & $T$ \\
\hline$r \varepsilon$ & 17 & 10 & 9 & $7 \vee \Lambda$ & $r$ \\
\hline$r r$ & IV & 70 & 1. & $r \mu$ & $\bar{r}$ \\
\hline$r$. & 11 & 0. & 11 & $r \cdot \theta$ & $\varepsilon$ \\
\hline$r V$ & 19 & $\varepsilon V$ & Tr & 179 & 0 \\
\hline rr & $r$. & $r q$ & ir & 111 & $\frac{7}{7}$ \\
\hline$\leqslant 7.0$ & YI. & $r \mu$ & $T \varepsilon$ & 99 & $\mathrm{~V}$ \\
\hline
\end{tabular}

إجابة التساؤل الثانى: ما الأسماء المفردة والمركبة بيـن مو اليد المصريين؟

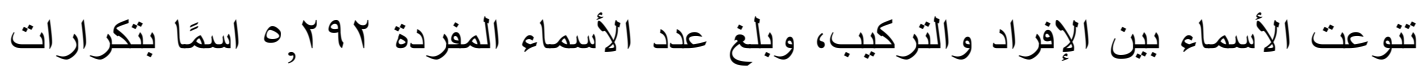

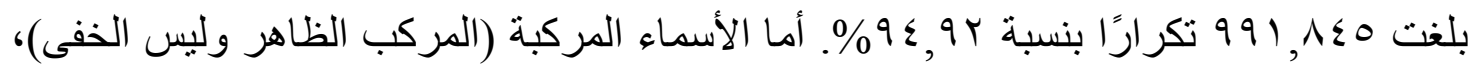
فكان أغلبها ناتجًا دن وجود (أبو، أم، عبد، أبا، ابن، سيف) قبل الاسم، أو وجود (الدين)، أو لفظ الجلالة بعد الاسم.

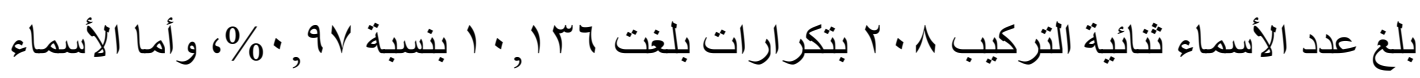

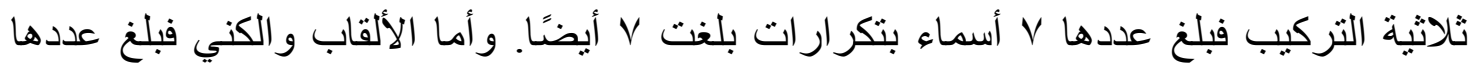

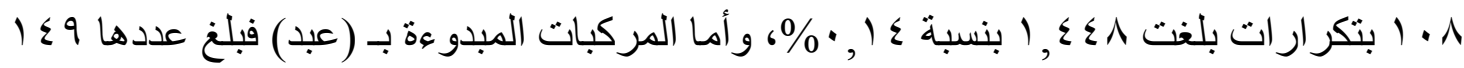

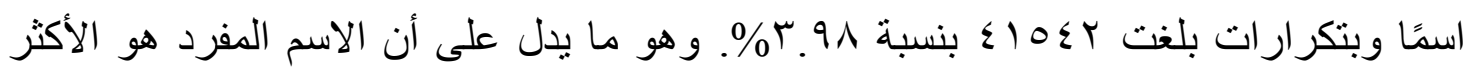

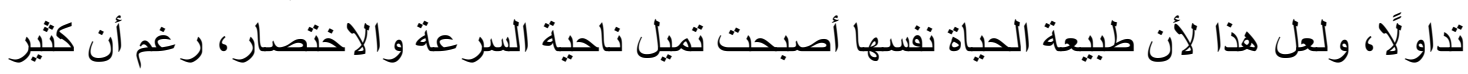
من الأسماء المركبة كانت تقدم معلومات إضافية، وكان الاسم المركب أكثر انتشارًا في العصور

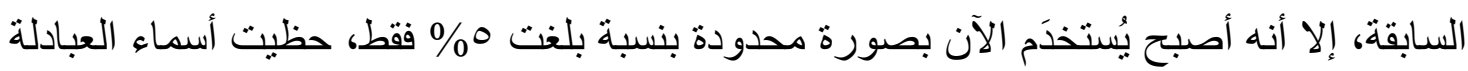

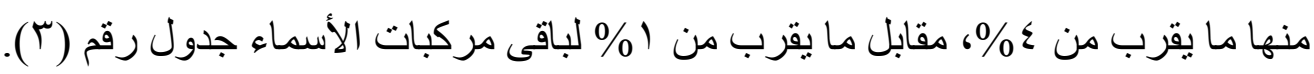

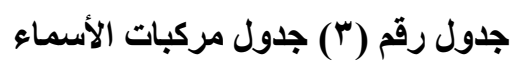

\begin{tabular}{|c|c|c|c|c|}
\hline$\%$ & التكر ار ات & $\%$ & العدد & نوع الاسم \\
\hline $0 \% 9 \leq .94$ & $9911 \leq 0$ & $0 \% 91 . \wedge 1$ & OY9Y & أسماء مفردة \\
\hline$\% \cdot .9 V$ & 1.1147 & $\%$ & $r \cdot \Lambda$ & اسم مركب ثنائي \\
\hline$\% \cdot \cdots$ & V & $\% \cdot .1 T$ & V & اسم مركب ثثلاثي \\
\hline$\% \cdot .1 \leq$ & $1 \leqslant \varepsilon \wedge$ & $\% ! . \wedge V$ & $1 \cdot 1$ & لقب وكنية \\
\hline$\% \Gamma .91$ & $\leqslant 10 \leqslant Y$ & $\%$ Y.09 & $1 \leqslant 9$ & مركب مبدوء بعبد \\
\hline$\% 1 \ldots$ & $1 . \leq \varepsilon 9 \vee \wedge$ & $\% 1 \ldots$ & OVT & المجموع \\
\hline
\end{tabular}

يعرض جدول رقم (ع) أعلى الأسماء المفردة والمركبة، حيث يظهر أن الأسماء المفردة

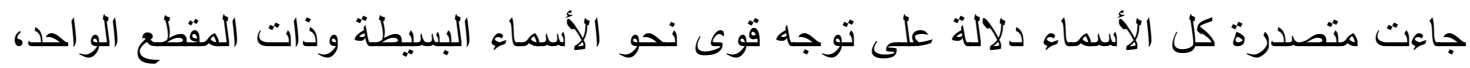
باستثناء المركبات المبدوءة بـ (عبد) و التي تفوق فيها اسمان على بعض الأسماء المفردة؛ فاحتل 


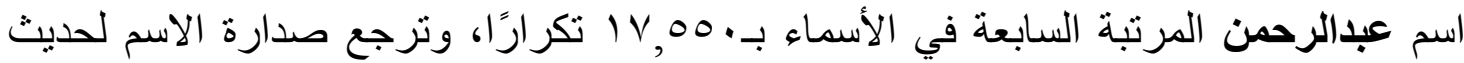

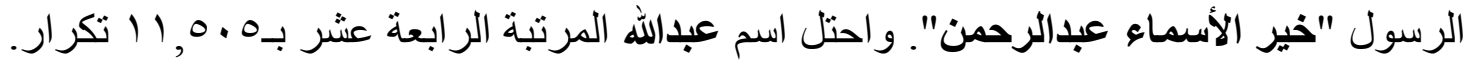

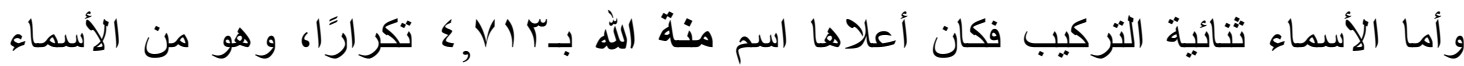

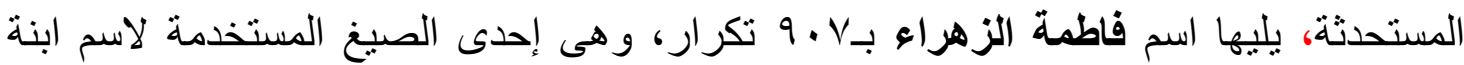

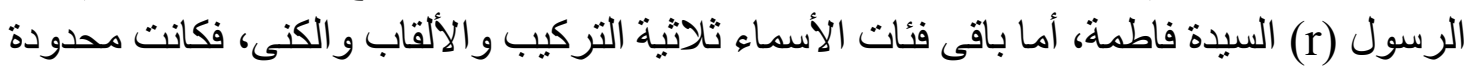

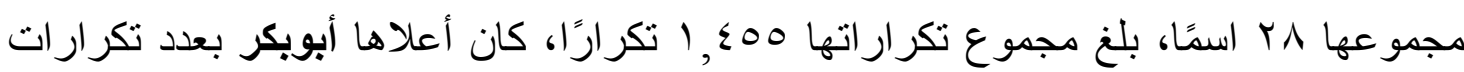

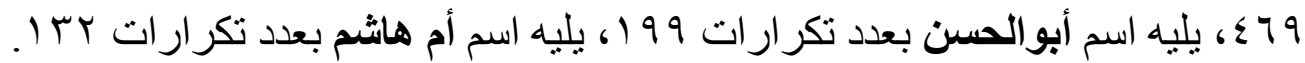

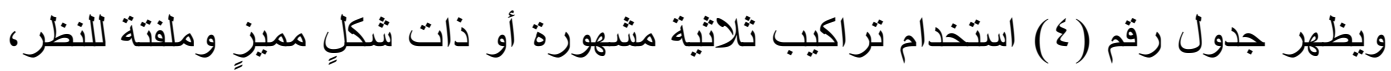

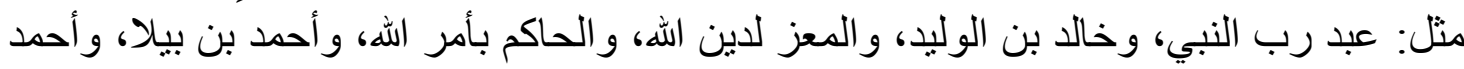

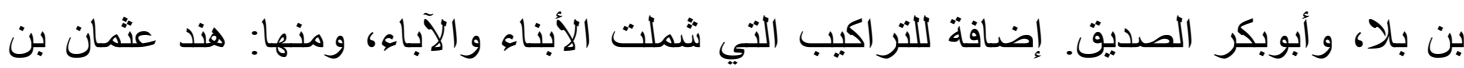
عفان، عبداله عمر بن الخطاب، معالى الأمير محمد الأمير.

جدول رقم (ع) تكرارات الأسماء المركبة

\begin{tabular}{|c|c|c|c|c|c|c|c|c|c|}
\hline \multicolumn{2}{|c|}{ مركب مبئزs بيجيد } & \multicolumn{2}{|c|}{ لقب وكتية } & \multicolumn{2}{|c|}{ اسم مركب ثلاثنى } & \multicolumn{2}{|c|}{ أمح مركب ثئئي } & \multicolumn{2}{|c|}{ أسمأ مقردة } \\
\hline ألتكر أز & الالاسم & ألتئر أز & الاسسم & أiتكر ازل & الاسم & ألتكر أز & الاسم & ألتئر أز & الاسم \\
\hline IVos. & تيد اليرحمن & 894 & ائبويكز & $\overline{1}$ & تيد رب التبي & EVIT & متة ألها & $1.04 T T$ & محمد \\
\hline 110.0 & تيدأتها & 194 & أبوألحسن & 1 & 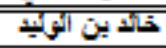 & $4 . \mathrm{V}$ & 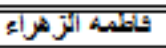 & A.VII & احمد \\
\hline 1011 & تيد ألمزيز & 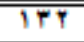 & أم هائم & $\overline{1}$ & أمعزلكين أنه & $\xi \wedge$ & هبة ألهـ & Tr\$0\% & محمود \\
\hline $1 \leqslant V Y$ & تيد ألحميث & 74 & أنوزيد & 1 & أحكمث بأمر الثئ & $\sum \pi \mathrm{VV}$ & توزئأُيني & TTYOD & الية \\
\hline VFV & تيدالفتأح & 01 & أم اكثىم & 1 & أحمد بن يبلا & $\overline{T \wedge A}$ & كيف أليدين & $7.1 \leqslant 4$ & أسمأ \\
\hline VI. & تيبا|نمتع & $\xi \xi$ & أبتوالحمد & 1 & احمد بن بلا & $7 \% 4$ & حسأم الثين & IAYOY & مصطقي \\
\hline 2017 & 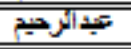 & $\sum \xi$ & 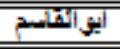 & 1 & أبويكر أنصلئئي & Fvo & 年 & 179\%. & إبراء \\
\hline$\Leftrightarrow \% \mathrm{~V}$ & تيد أنو هئب & $\overline{\varepsilon \xi}$ & أبثي أمجيد & $\overline{\mathrm{V}}$ & & 710 & تولاع ألدين & $1715 \xi$ & إيملن \\
\hline$\$ 10$ & تيثبأسمانة & $\overline{T \varepsilon}$ & أبوأسمرود & & & $\overline{I N T}$ & 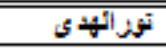 & $1+\Lambda \leq \leqslant$ & (25 \\
\hline TVY & تئب ألعظيح & i. & 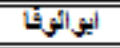 & & & IVI & عسلاع الثين & $1+19$ & شيماء \\
\hline FVT & تيدأكريخ & IV & أبئأيزيزيد & & & $1 \leqslant \mathrm{~V}$ & إية ألثه & IYAY. & إبسلاتم \\
\hline Tor & 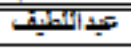 & 17 & أيوالكحجاع & & & $1 \ldots$ & ثنهباتب ألدين & $117 \mathrm{~V}$ & أميرة \\
\hline$T \cdot T$ & تيد أنهادي & 10 & أبوأنتير & & & AT & خياء ألهين & $1.7 \%$ & يأسمين \\
\hline 7.1 & تيد أُتأصر & 10 & أبوأملا & & & 10 & بأهاءكأندين & $1 . \$ 7 T$ & إيراهيخ \\
\hline TAV & تَبدأكلئيح & 17 & أئي القتشترع & & & $\overline{V A}$ & تمشاد الكين & $1 \cdot \xi \cdot \Lambda$ & مريد \\
\hline TV4 & تيد أنقائر & 17 & انيوخنيق & & & 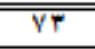 & تعبد لتَبي & 4984 & تعلى \\
\hline ToT & 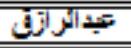 & 11 & أبوالفتضل & & & $\xi \hbar$ & كيف الإيسلام & कVशT & توزئن \\
\hline 7.1 & تَبدالتتب & 1. & أم السعت & & & $\xi 1$ & زين العائين & AOTT & تدي \\
\hline 7.1 & تيث ألمجيد & 1. & أيوأَد هب & & & $\$ 4$ & ألمتصن بالثه & AT\&. & سمزئ \\
\hline 191 & تيذأسل & 1. & أيو أمعافي & & & $\$ 0$ & تصبر ألدين & $911 \%$ & ئوسف \\
\hline 19. & تيدألمكيم & 1. & أم أنتيّر & & & & …...... & 1109 & 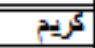 \\
\hline ह10? & & $1 \leqslant \leqslant \wedge$ & & & & 1.174 & & कदारह0 & \\
\hline
\end{tabular}


إجابة التساؤل الثالث: ما تأثير طول الاسم على انتشاره؟ تراوحت أطو ال الأسماء بين حرفين وحتى ع ا حرفًا، مع استبعاد المسافات من الأسماء

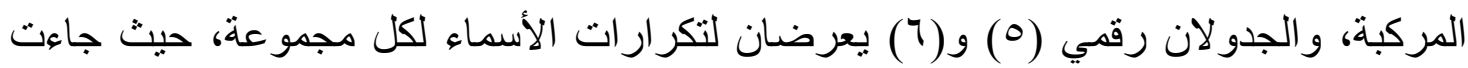

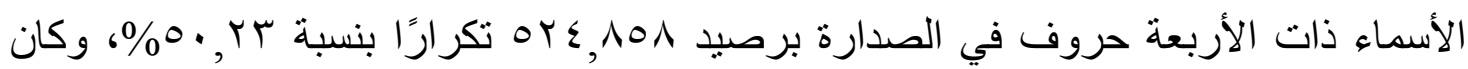

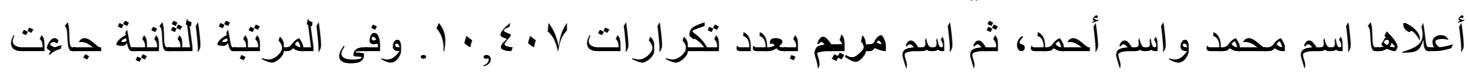

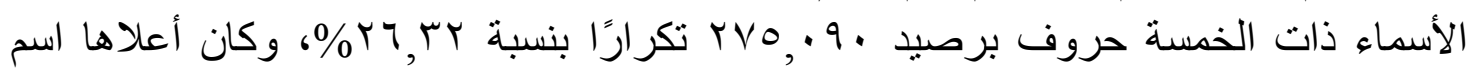

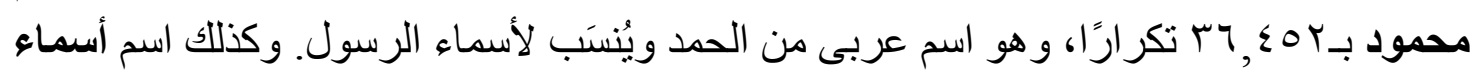

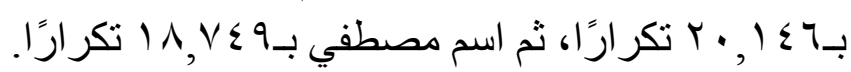

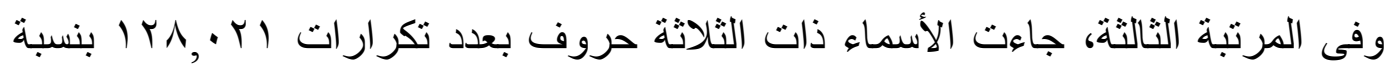

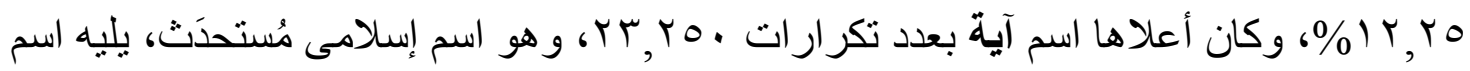

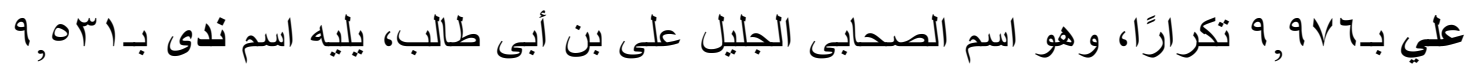

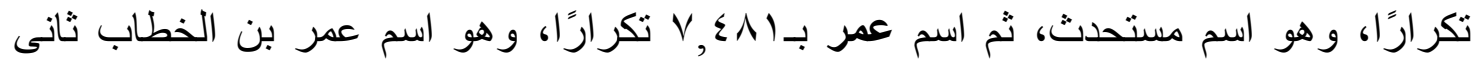
الخلفاء الر اشدين.

وحظيت الأسماء المكوّنة من حرفين على المرنبة السابعة برصيد 07 وه تكرارًا بنسبة أقل من (\%) وكان أعلاها اسم مي بـو ( تكرارًا وهو اسم عربى لا يز ال يحظى بالقبول لخفته

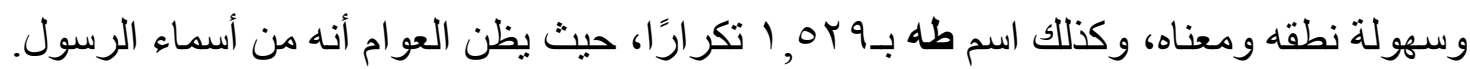

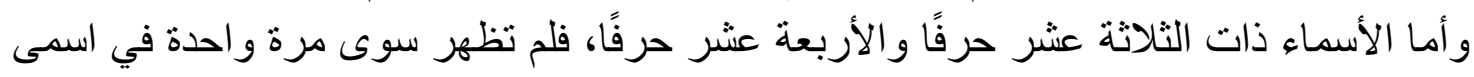
"المعز لاين الله" و "الحاكم بأمر الله". ويمكن تبرير ذللك الميل إلى الأسماء المتوسطة الطول دئه

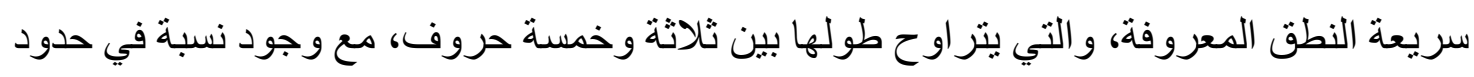

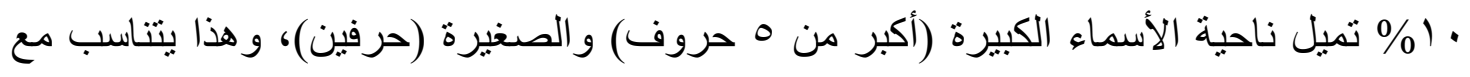
التوزيع الطبيعى. نئ. جدول رقم (0) أطوال الأسماء

\begin{tabular}{|c|c|c|c|c|c|}
\hline$\%$ & التكرار & عدد الحروف & $\%$ & التكرار & عدد الحروف \\
\hline$\%$ \%.9r & $r .079$ & 9 & $\% \cdot .0 \mathrm{~V}$ & 0970 & $T$ \\
\hline$\% \cdot . r$ & rVq & 1. & \% & $|r \wedge . r|$ & r \\
\hline$\% \cdot . \cdot 1$ & $9 \varepsilon$ & 11 & $\% 0 \cdot r r$ & Or $\leqslant \wedge O \wedge$ & $\varepsilon$ \\
\hline$\% \cdot .9$ & qVY & ir & \% \% & rvo. 9. & 0 \\
\hline$\% \cdot \ldots l$ & 1 & M & $\%$ r.vq & r909V & 7 \\
\hline$\% \cdot \ldots l$ & 1 & $1 \varepsilon$ & $\%$ r. $\leqslant 7$ & MI $\leqslant V$ & V \\
\hline$\% 1 \ldots$ & $1 . \leq \leq 9 \vee \wedge$ & & $\% \cdot r r$ & rMs & $\wedge$ \\
\hline
\end{tabular}




\section{جدول رقم (†) الأسماء الأعلى تكرارًا لكل فئة حروف}

\begin{tabular}{|c|c|c|c|c|c|c|c|c|c|c|c|c|c|c|}
\hline \multicolumn{3}{|c|}{ ستة حروف } & \multicolumn{3}{|c|}{ خستة حروف } & \multicolumn{3}{|c|}{ أريعة حروف } & \multicolumn{3}{|c|}{ ثلاثة حروف } & \multicolumn{3}{|c|}{ حرقين } \\
\hline$\%$ & التكررJ & |لاسم & $\%$ & التثرل & الاسم & $\%$ & التكرل & الأسم & $\%$ & التئرل & الاسـ & $\%$ & التئرل & |لاسم \\
\hline$\%$ \%, & $1 ., \mathrm{NT}$ & باسنين & $\%$ ir. ro & mor & محموي & $\%$ \%...1 & $1.04 \times$ & محد & $\% \backslash 1 \wedge$ & rero. & آية & $\% \vee \cdot,{ }^{2}$ & $\$ 19 \%$ & مي \\
\hline$\%$ \% & avar & تورهان & \%verr & $4.1 \leq 4$ & أسماء & $\% 10, \mathrm{rA}$ & A.VII & أحد & $\%$ \%.v 4 & 4985 & تطبي & $\%$ \% . & lora & طه \\
\hline$\% 0,0$ & riov & صايرين & $\%$ \% :Ar & IAv $\leqslant 9$ & مصطقب & $\% 1.4 \wedge$ & $1.5 . v$ & هريخ & \%v.s & aori & تدي & $\% 1, \%$ & $9 \mathrm{~V}$ & تز \\
\hline 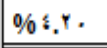 & no & ماريثا & $\% \div 10$ & $189 \times \mathrm{V}$ & إبر اءs & $\%$ 1.v^ & $4 \pi \leqslant$. & سارة & $\% \circ, \wedge \leqslant$ & $v \leqslant 11$ & تمدر & $\%$ 1.1r & iv & يس \\
\hline$\% r .4 r$ & $100 \mathrm{r}$ & اباتوبي & $\%: . \cdot 0$ & 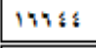 & إيمان & $\%$ \%,v & 9101 & يوسف & $\%: r \leq$ & 0004 & حسن & $\% \cdot v \leq$ & 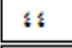 & ضبي \\
\hline$\% r . v v$ & $1: 4 r$ & ابتسلم & $\% \bullet . . r$ & 17Ns & قاطدة & $\% 1.00$ & 1109 & كريم & $\%\{, r$ & oras & متب & $\% \cdot r r$ & 19 & آن \\
\hline$\% 1 . \% \mathrm{~V}$ & $m$ & لدياتة & $\% \vdots \wedge$ & ITris & شينياء & $\% 1.00$ & A1: & هاجر & $\%$ \% .4r & $0 . r^{2}$ & هية & $\% \cdot .1$ & $\checkmark$ & 20 \\
\hline$\% 1 .\{$ & 005 & سليمان & $\%$ \%: & $1 \times 119$ & إسلام & $\% 1, r:$ & $v \cdot r$. & بيتا & \%r.rr & \&rsv & المل & $\% \cdot \cdot v$ & $\vdots$ & ست \\
\hline$\% 1.11$ & $\leqslant 4$ & أبويكر & $\%$ \% r T & 118rs & أميرة & $\%$ \% prr & 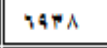 & متار & $\% r . r 1$ & stre & تدا & $\% \cdot .^{r}$ & $r$ & سر \\
\hline$\%$ 1.1r & « & الحسين & $\% 1.4$ & ora: & السي & $\%$ \%,rv & Bur & دتاء & $\%$ \%.. 1 & PNos & سمر & $\% \cdot .^{r}$ & 1 & هل \\
\hline$\% 1 \ldots$ & $P 40 Q V$ & & $\% 1 \ldots$ & rvo.a. & & $\%$ & 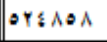 & & $\% 1 \ldots$ & $1 \times \Lambda .+1$ & & $\% 1 \ldots$ & 0470 & |الإجمالئ| \\
\hline
\end{tabular}

إجابة التساؤل الر ابع: ما الصيغ المختلفة للأسماء؟

من الأمور اللافتة للنظر، والتي تكررت بكثرة مع أسماء المواليد، تعدد الصيغ المُستخدَمة

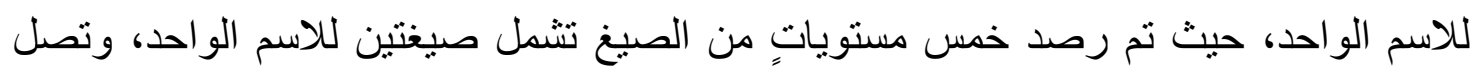
حتى ست صيغٍ. وجدول رقم (V) يعرض لكل مستوى من الصيغ، و عدد الأسماء بها، و المجموع الكلى للأسماء.

جدول رقم (V) الصيغ المستخدمة

\begin{tabular}{|c|c|c|c|}
\hline تكر ار ات الأسماء & عدد الأسماء & عدد صيخ الاسم & 5 \\
\hline$\lambda \leqslant Y r q$ & 101 & صيغتان & 1 \\
\hline rq $q 0$. & rA & ثنلاث صيغ & $r$ \\
\hline 19.4. & $\pi$ & أربع صيخ & $r$ \\
\hline r9V7r & 11 & خمس صيغ & $\varepsilon$ \\
\hline loVY & $\varepsilon$ & ست صبغ & 0 \\
\hline
\end{tabular}

وكما يظهر، فإن الصيغ الثنائية كانت الأكثر عددًا و الأكثر تكرارًا، يليها الثلاثية فالرباعية فالخماسية فالسداسية. ويعرض الجدول رقم (^) الصيغ الثنائية والثناثية المُستخدَمة مع أكثر الأسماء شهرة. 
جدول رقم (^) الصيغ الثنائية والثلاثية

\begin{tabular}{|c|c|c|c|c|c|c|c|c|c|c|}
\hline \multicolumn{6}{|c|}{ الصيخ الثلاثية } & \multicolumn{4}{|c|}{ الصيغ الثنائية } & \multirow[b]{2}{*}{ s } \\
\hline العدد & صالثةة & العدد & ثينية & العدد & صلّيغة & العدد & ثيغنة & العدد & صيغلة & \\
\hline 7 & مروا & س & مروي & $\pi r \cdot V$ & مروة & 1 & إثراء & 1794. & اسر اء & 1 \\
\hline 1 & نوراه & qAV & نورة & OTYE & نورا & 1 & فطمه & $1 \Gamma \wedge \varepsilon \varepsilon$ & فاطمة & r \\
\hline 1 & سلما & rr & سلمة & M & سلمي & 1 & رحما & $01 \leqslant r$ & رحمة & r \\
\hline r & داليه & 19 & دليا & אדצץ & داليا & 0 & هبا & $0 . r 4$ & هبة & $\varepsilon$ \\
\hline IV & سهيلا & $r \varepsilon$ & سو هيلة & $1 \wedge 94$ & سهيلة & 。 & منت اله & svir & منة الله & 0 \\
\hline 1 & منت & 19 & منا & 171. & منة & 1. & ثمر & r人os & سمر & 7 \\
\hline 7 & رضوا & 119 & رضوه & Irra & رضوى & 1 & حوسين & $r \leqslant Y \wedge$ & حسين & v \\
\hline 1 & نجوا & 7 & نجوة & 1.17 & نجوي & TrT & هنا & rrin & هناء & $\wedge$ \\
\hline 11 & يحبا & rod & يحي & NIr & يحيب & $\varepsilon$ & نيرا & $19 . \varepsilon$ & نيرة & 9 \\
\hline 1 & مو عاذ & $\varepsilon r$ & معاز & $V Y q$ & معاذ & lor & مومن & lor. & مؤمن & 1. \\
\hline
\end{tabular}

و أما الصيغ الثلاثية، فكان من بين ما تضمنته من أسماء: مروة ومروي ومروا، نورا ونورة ونور اه، سلمي وسلمة وسلما، سهيلة وسو هيلة وسهيلا، نجوي ونجوة ونجوا، معاذ ومعاز

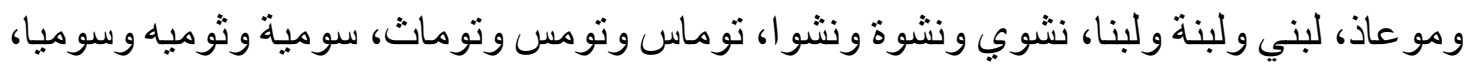
مهجة و مهجت ومو هجه، حارس وحارص وحارث، ذكره وذكر ا وزكرة. وأما الصيخ الرباعية، فكان من بين ما تضمنته من أسماء: حسناء وحسنة وحسنا وحوسنه، بسنت وباسنت وبثتت وبيسنت، نهي ونها ونو ها ونوها، بسملة وبسملا وباسملة وبسماله، صموئيل وصمائيل وصو مائيل وصوئيل، ميساء وميسة و ميسا و ويناء.

و أما الصيغ الخماسية، فكان من بين ما تضمنته من أسماء: سارة وسار ا وصارة وثاره وسار اه، كيرلس وكرلس وكيرليس وكرليس وكيرلص، يمنى ويامنة ويمنه ويمنا ويومنه، سها وسهي وسو ها وسو هله وسهه.

وأما الصيغ السداسية، فكان من بين ما تضمنته من أسماء: كرستينا وكريستينا وكرستينة وكريستنا وكرسيتنا وكريسينا، روميساء ورميساء وروميثاء وروميصاء وريناء ميصاء وريناء وريثاء. 


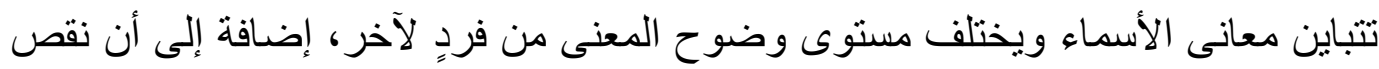

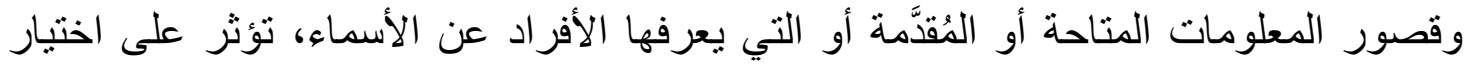
الاسم كما تؤثر في انتشاره بالزيادة أو النقصان. كما أن الجهل بطريقة الكتابة جعل أسماء كثيرة

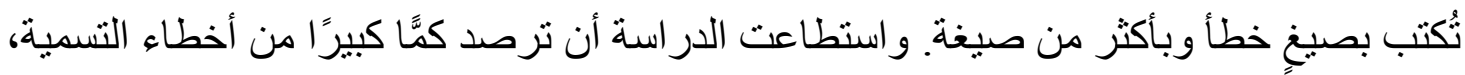
إضافة لتعدد أثكال كتابة الأسماء، وكانت أخطاء الأسماء: إما خطأ في كتابة الاسم لم لم يتم تصحيحه، أو أن الاسم لم يُكتب خطأ و إنما سُجِّل هكذا بنفس الشكل في السجلات. و استطاعت التهاء

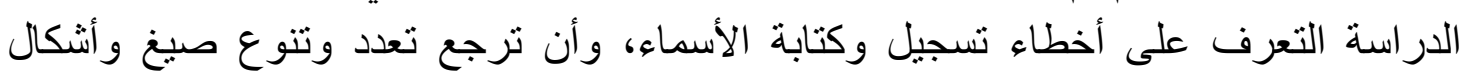

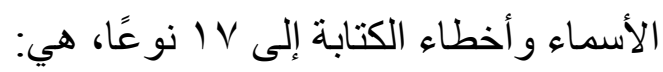

(1) استخدام حرف بدلا من آخر لتقارب الحرفين في النطق مثل (س، ث) كما في: إسراء

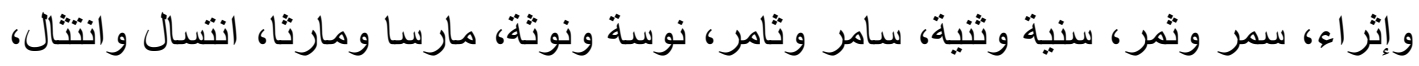

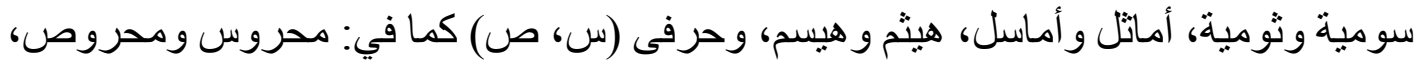

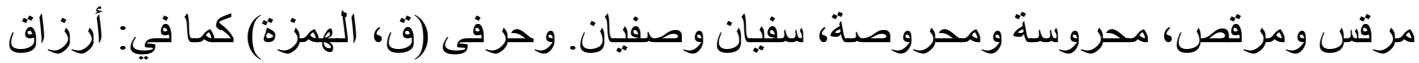

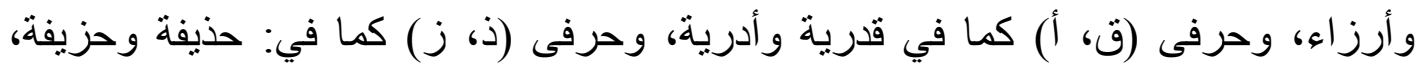

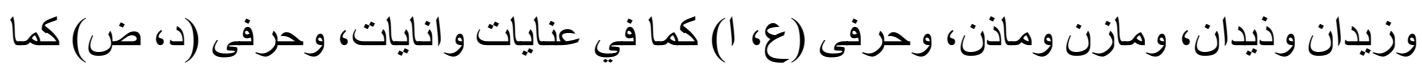
في: حيدر وحيضر، مودى وموضى، حمد الله وحمض الله، وحرفى (د، ت) كما في تفيدها

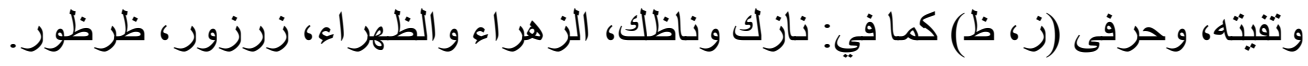

(Y) أخطاء تبديل أماكن بعض الحروف، منل: فتحى وقتحى، عبدالحميد و عبدالحيمد، عبداللطيف

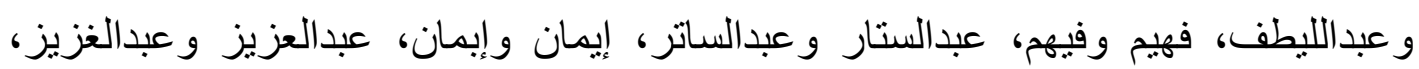
رمضان ورمضام (و الأخيرة قد تكون خطأ نطق).

(ץ) حذف الحرف للتخفيف في النطق كما في: فاطمة وفطمه، ماجدة ومجدة، ميخائيل ومخائيل، فر اولة وفرولة، أو حذف الهمزة من النطق كما في لمياء ولميا، هناء وهنا، سناء وسنا، إسحاق وهن وهن

$$
\text { واسحق، سليمان وسليمن، واهبة وو هبة. }
$$

(ع) تحويل علامة التشكيل للحرف المقابل (الفتحة لألف، و الضمة لواو، و الكسرة لياء) كما في: حُسين وحوسين، رقية وروقية، أميمة وأوميمة، نهال ونيهال، مهاب وموهاب، مشيرة

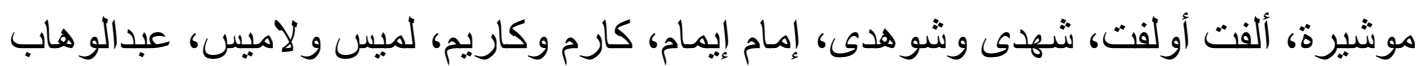

$$
\text { و عبدالو اهاب، و عبدالصبور الفور و عبدالصابور . }
$$

(0) استبدال الألف و الهاء و التاء المربوطة والياء كما في: هبة وهبا، يسر اويسرة، تقوى وتقوه، مروة ومروى، سهاو وسهى. (؟) وضع التاء المربوطة مكان الهاء: آية الله وآية اللة، جنة الله وجنة اللة، منة اللة ومنة الله. (V) تحويل الواو المهموزة لواو عادية كما في: مؤمن ومومن، مؤمنة ومومنة. 
(^) تحويل التاء المربوطة لتاء مفتوحة و العكس كما في: منة الله ومنت الله، سمية وسميت، آمنـة و وآمنت.

(9) التبديل بين حالات الرفع و النصب كما في: أبوبكر و أبى بكر ، أبوسفيان و أبى سفيان.

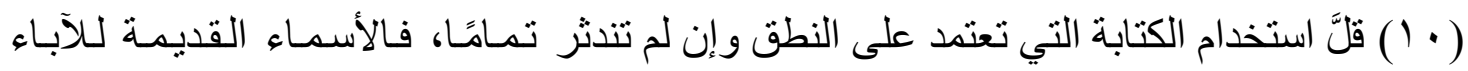

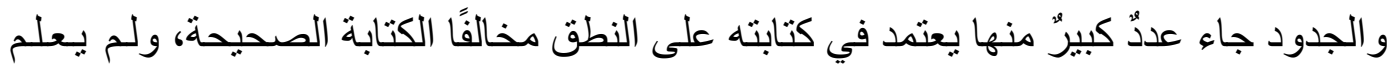

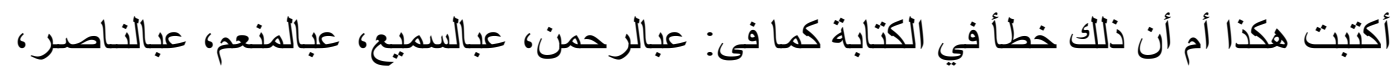

$$
\text { عبالو هاب، عبالعزيز ، عبالكريم. }
$$

(1 (1) ) تكر ار الياء، مثل: جاكلين وجاكليين، حسانين وحسانيين، وحسنين حسنيين.

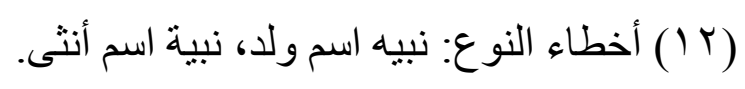

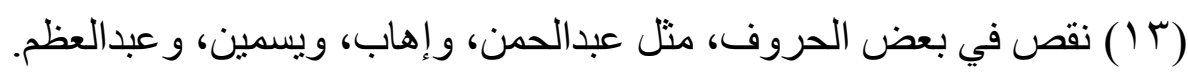

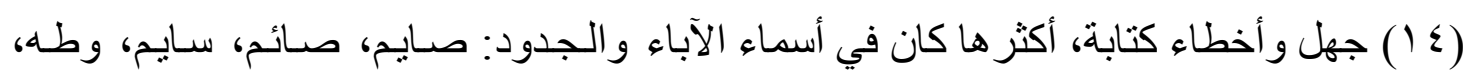

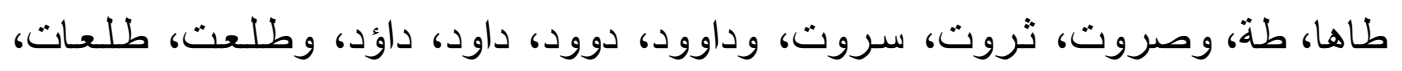
وطار ع، طارئ، طارق.

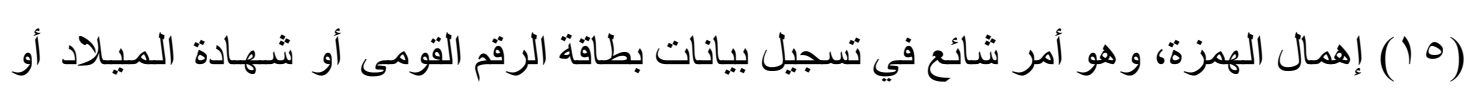

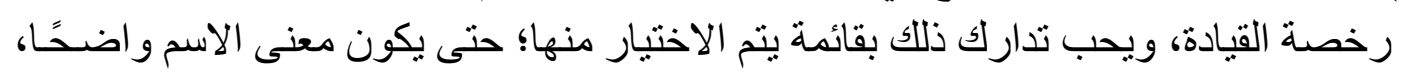

$$
\text { وحتى يعتاد الناس على طريقة كتابته الصحيحة. }
$$

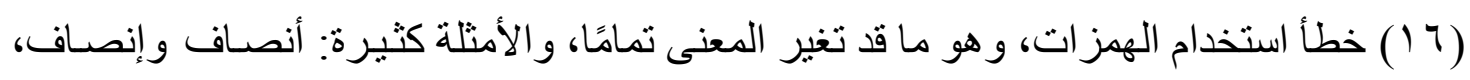

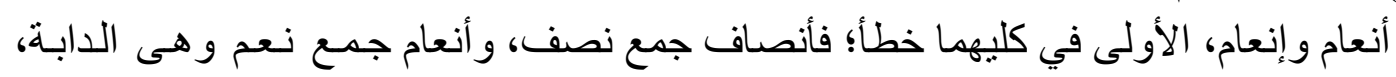

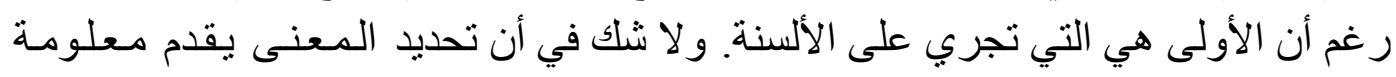

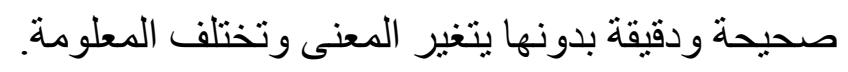

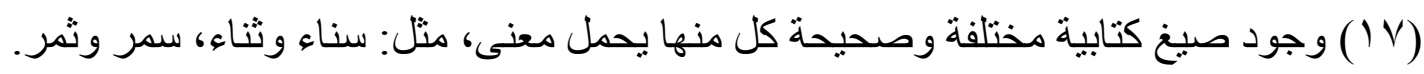
إجابة التساؤل الخامس: ما تأثثر الجنس على التسمية؟

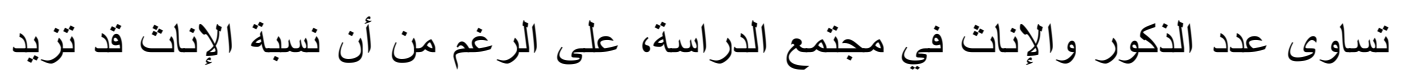

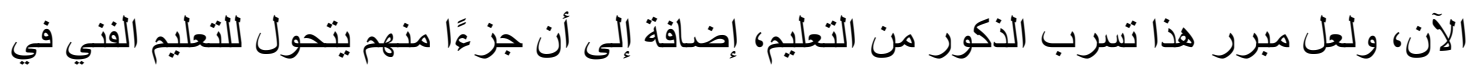

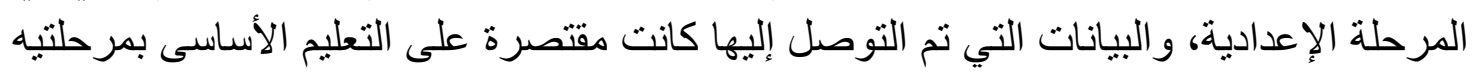

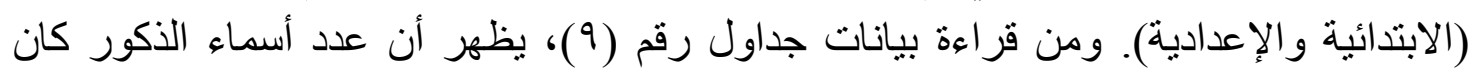

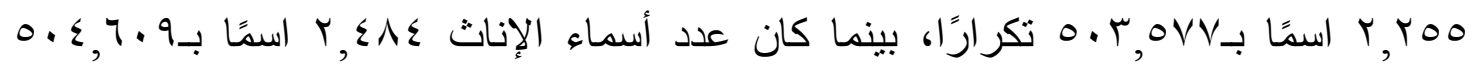

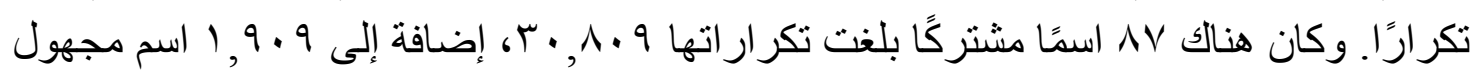

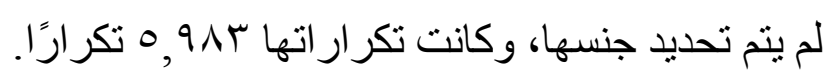




\section{جدول رقم (9) جنس الاسم}

\begin{tabular}{|c|c|c|c|c|}
\hline$\%$ & الت التكرار & $\%$ & 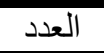 & النوع \\
\hline$\% \leqslant \Lambda .19$ & $0 . r 0 \mathrm{VV}$ & $\% \cdot . Y Y$ & TrOO & ذكور \\
\hline$\% \leqslant \Lambda . Y q$ & 0.57 .9 & $\% \cdot . Y \varepsilon$ & $r \xi \Lambda \varepsilon$ & إناث \\
\hline$\%$ \%.90 & $r \cdot 1 \cdot q$ & $\% \cdot .1$ & NV & سماء مشتركة بين الذكور و الإناث \\
\hline$\% \cdot .0 \mathrm{~V}$ & 0914 & $\% \cdot .11$ & 19.9 & مجهول / غير محدد \\
\hline$\% 1 \ldots$ & $1 \cdot \varepsilon \varepsilon 9 \vee \wedge$ & $\% \cdot .7 \varepsilon$ & TVTO & المجموع \\
\hline
\end{tabular}

ويعرض جدول رقم (• () الأسماء التي تصدرت كل جنسٍ، فتصدر أسماء الذكور: محمد وأحمد ومحمود ومصطفي وعبدالرحمن وعبدالله وإبراهيم وعلي ويوسف وكريم وعمر وخالد،

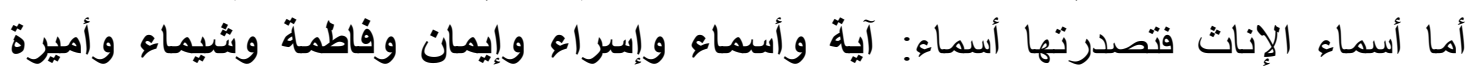

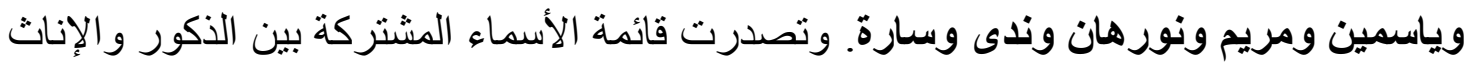
أسماء: إسلام وندا وحسن ورضا وأشرف وعزة ونور وتقى وإلهام ووسام ونهال وشمس،

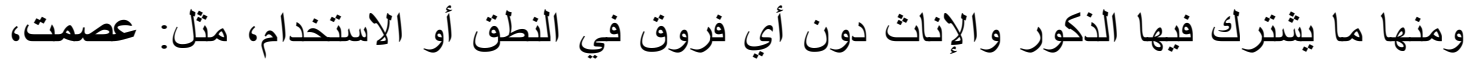

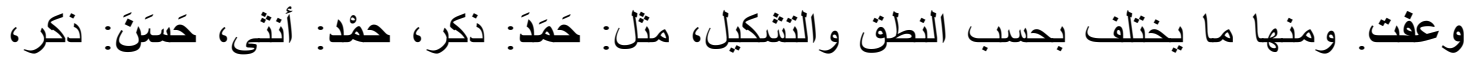

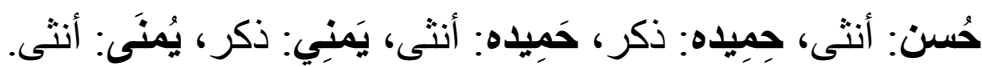
ورغم أن أسماء الإناث يغلب عليها الانتهاء بياء أو هاء أو تاء، إلا أن أسماء عدد من الذكور كانت أيضًا تتنهى بنفس النهايات، مثل: إكر امي، بكري، تهامي، حسني، خيري، سامي، صبحي،

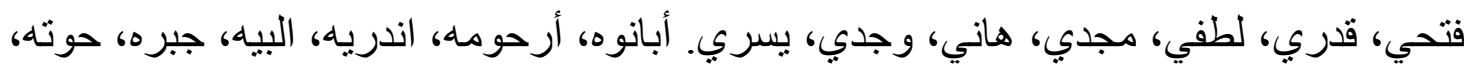

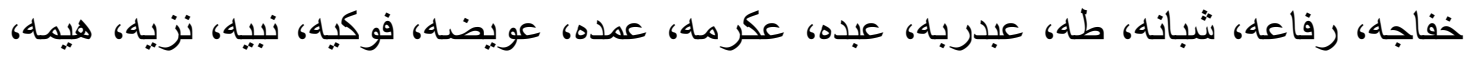
وجيه. مدحت، ر أفت، طلعت، رفعت، ثابت، نشأت، فرحات، عصمت، حشمت، بهجت، شوكت،

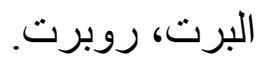


جدول رقم (· (1) الأسماء وفقًا للجنس

\begin{tabular}{|c|c|c|c|c|c|c|c|c|}
\hline \multicolumn{3}{|c|}{ أسماء مشتركة بين الأكور والإناث } & \multicolumn{3}{|c|}{ إناث } & \multicolumn{3}{|c|}{ ذكور } \\
\hline$\%$ & التكر ار & 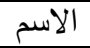 & $\%$ & 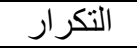 & الاسم & $\%$ & 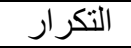 & 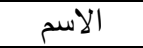 \\
\hline$\%$ & $1 \cdot Y I T$ & إسلام & $\%\{.71$ & TMYOO & أية & $\%$ \% .. & 1.09 .1 & محمد \\
\hline$\%$ & ro.v & ندا & $\% r .99$ & $r \cdot 1 \leq 7$ & أسماء & $\% 17.4$ & 1.790 & أحمد \\
\hline$\%$ & $r \leqslant 09$ & حسن & $\%$ \% r. & 17910 & إسر اء & $\% \vee . Y \leq$ & एา & محمود \\
\hline$\% 7.01$ & $r \cdot r V$ & رضا & $\%$ \%.r. & $177 \varepsilon 1$ & إيمان & $\%$ \% VY & $1 \wedge V \leqslant Y$ & مصطفي \\
\hline$\% \varepsilon . V T$ & $1 \leqslant 0 \wedge$ & أشرف & $\% \curlyvee . \vee \varepsilon$ & ITATM & فاطمة & $\%{ }^{r} . \leqslant 9$ & $1 v 0 \leqslant 9$ & عبدالرحمن \\
\hline$\% \varepsilon .+r$ & $1 T \varepsilon r$ & 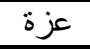 & $\%$ \%.TY & ITYI9 & شيماء & $\%$ \% Yᄉ & $110 \ldots$ & عبداله \\
\hline$\%$ \%. ¿V & $V 7$. & نور & $\%$ \%.r. & $117 Y V$ & أميرة & $\%{ }^{\prime} . \cdot V$ & $1 \cdot \leqslant 1 V$ & إبر اهيم \\
\hline \% & VTr & تقي & $\%$ \%.11 & $1.7 \pi \leq$ & ياسمين & $\% 1.9 \wedge$ & $99 \vee 4$ & علي \\
\hline$\%$ \% & 10 & إلهام & $\% \%^{Y} .{ }^{\top}$ & $1 \cdot \varepsilon \cdot \Lambda$ & مريم & $\% ! . \wedge r$ & 9109 & يوسف \\
\hline$\%$ r. 19 & $7 \vee 0$ & وسام & $\% 1.94$ & $9 \vee 7 r$ & نور هان & $\% 1.7 r$ & NIOV & كريم \\
\hline$\%$ \%.r & TrT & نهال & $\%) . \wedge \wedge$ & $9 \leqslant 70$ & ندي & $\% ! . \leqslant 9$ & $V \varepsilon \wedge r$ & عمر \\
\hline$\% 1.49$ & rqv & شمس & $\% ! . \wedge 0$ & 9Mr & سارة & $\% ! . Y \leq$ & $7 r \leq 7$ & خالد \\
\hline$\% 1 \ldots$ & $r .1 .9$ & & $\% 1 \ldots$ & D. & & $\% 1 \ldots$ & $0 . M 00 Y$ & \\
\hline
\end{tabular}

إجابة التساؤل السادس: ما تأثثر أل التعريف في التسمية؟ على الر غم من أن الألف و اللام تُستخدم للتعريف في اللغة، و أسماء الأعلام بطبيعتها معرفة، فإن عددًا كبيرًا من الأسماء جاء مسبوقًا بالألف واللام، ووفقًا لوجود الألف واللام تلام تم تقبيم

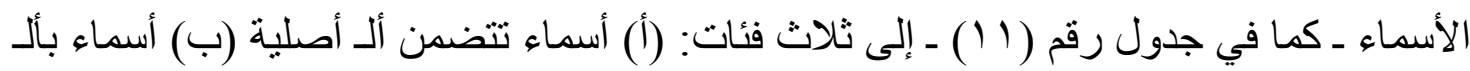

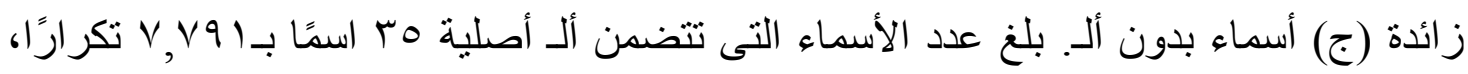
منها أسماء: آلاء، إلهام، ألفت، ألطاف، ألبير، إلهامي، آلاء الرحمن، آلاء الله، إلباس، ألماظ،

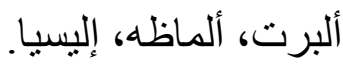

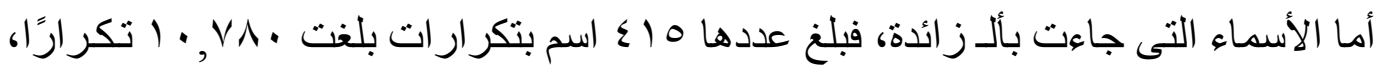

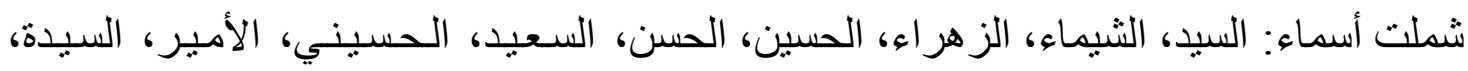

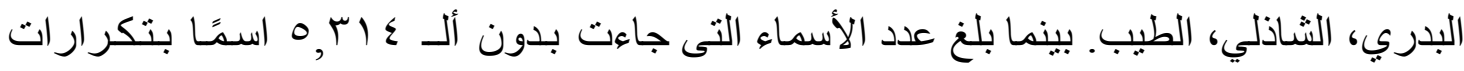

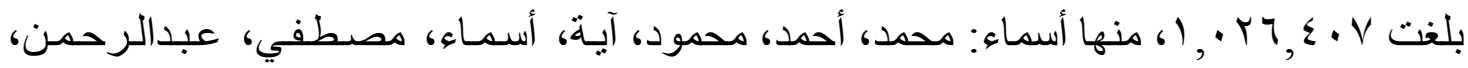
إسر اء، إيمان، فاطمة، شيماء، إسلام، أميرة.

جدول رقم (1 1) ال التعريف

\begin{tabular}{|c|c|c|}
\hline$\%$ & العدد & ال التعريف \\
\hline$\% 9 r .19$ & orls & أسماء بلون أل \\
\hline$\% \vee . Y$. & $\leqslant 10$ & أسماء بال زائدة \\
\hline$\% \cdot .71$ & ro & أسماء تتضمن ال أصلية \\
\hline$\% 1 \ldots$ & OVTE & المجموع \\
\hline
\end{tabular}


جدول رقم (r T ) الأسماء وفقًا لألـ للتعريف

\begin{tabular}{|c|c|c|c|c|c|c|c|c|}
\hline \multicolumn{3}{|c|}{ أسماء تتضمن ال أصلية } & \multicolumn{3}{|c|}{ أسماء بال زائدة } & \multicolumn{3}{|c|}{ أسماء بلون أل } \\
\hline$\%$ & التكرار & الاسم & $\%$ & التكرار & الاسم & $\%$ & التكرار & الاسم \\
\hline$\% \wedge r \leqslant 0$ & $7 \leq Y \leq$ & آلاء & $\% 0 \cdot . r$ & or95 & السيد & $\%$ & $1.09 \mathrm{rr}$ & محمد \\
\hline$\% \backslash$. & $1 \cdot \leq \varepsilon$ & إلهام & $\% 1 Y .79$ & $1 \% 41$ & الشيماء & $\% \vee . \wedge \top$ & $\Lambda \cdot V \| 1$ & أحمد \\
\hline$\%$ Y. Yo & 1100 & الفت & $\%{ }^{V} . \cdot \varepsilon$ & 109 & الز هر اء & $\%$ \%.00 & $r T \leq 0 Y$ & محمود \\
\hline$\% \cdot . Y V$ & YI & الطاف & $\%$ \%.1. & $\varepsilon \varepsilon r$ & الحسين & $\%$ \% . YV & TMYOO & آية \\
\hline$\% \cdot Y \leqslant$ & 19 & البيز & $\%$ \%.IT & 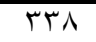 & الحسن & $\% 1.97$ & $T \cdot 1 \leq T$ & أسماء \\
\hline$\% \cdot . Y \leq$ & 19 & إلهامي & $\%$ & TrV & السعيد & $\%$ \% .А & INVOY & مصطفي \\
\hline$\% \cdot .10$ & ir & آلاء الرحمن & $\% r .+1$ & TIV & الحسيني & $\% ! . \vee 1$ & 1800. & عبدالرحمن \\
\hline$\% \cdot .10$ & ir & آلاء الله & $\% 1.00$ & $17 V$ & الأمير & $\% 1.70$ & 1794. & إسراء \\
\hline$\% \cdot .1 T$ & $1 \cdot$ & إلباس & $\% 1 . r 0$ & $1 \leq 7$ & السيدة & $\% 1.74$ & $177 \leq \varepsilon$ & إيمان \\
\hline$\% \cdot .1 \cdot$ & $\Lambda$ & ألماظ & $\% 1.1 \varepsilon$ & TrT & البدري & $\% 1 . r 0$ & $1 \pi \wedge \leq \varepsilon$ & فاطمة \\
\hline$\% \cdot . \cdot 7$ & 0 & ألبرت & $\% \cdot .71$ & 77 & الشـاذلي & $\% 1.19$ & $1 T Y 19$ & شيماء \\
\hline$\% \cdot .0$ & $\varepsilon$ & ألماظه & $\% \cdot . \leqslant 0$ & $\varepsilon 9$ & الطيب & $\% 1$. YO & ITAY. & إسلام \\
\hline$\% \cdot .0$ & $\varepsilon$ & إليسيا & & & & $\% 1.1 T$ & $117 r V$ & أمبرة \\
\hline ....... & ....... & ....... & ....... & ....... & ....... & ....... & ....... & ....... \\
\hline$\% \cdot . \vee 0$ & $V \vee 91$ & المجموع & $\% 1 .+r$ & $1 . \vee \wedge$. & المجموع & $\% q \wedge . Y Y$ & $1 . Y 7 \leqslant \cdot V$ & المجموع \\
\hline
\end{tabular}

بلغ عدد الأسماء التى تقبل دخول أل التعريف عليها، ووردت بالصورتين (أل وبدون ألـ)

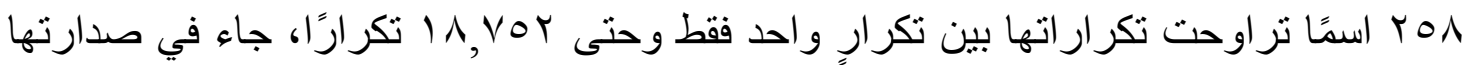

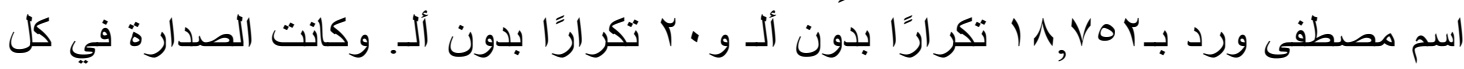

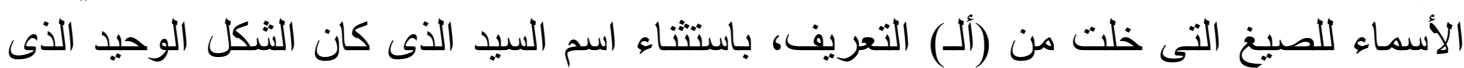

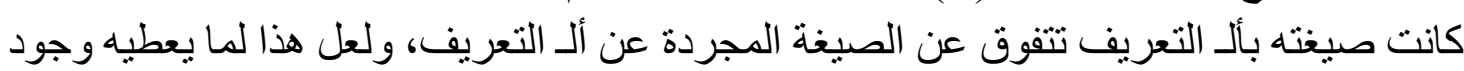
ألل التعريف لصاحب الاسم من لقبٍ وقيمة وسيادة.

جدول رقم (r ا ) أسماء وردت بصورتين (أل التعريف وبدونها)

\begin{tabular}{|c|c|c|c|c|c|c|c|}
\hline بدون أل & بأل & الاسم & م & بدون أل & بأل & الاسم & م \\
\hline ए1. & r & هدي & 11 & IAVOr & $r$. & مصطفي & 1 \\
\hline rVAq & 1 & فارس & 14 & $14 r 19$ & $14 \pi$ & شيماء & $r$ \\
\hline Y797 & 9 & وليد & Tr & $117 r V$ & rr & أمبرة & r \\
\hline rTN & 1 & طارق & $1 \leq$ & בז & 1 & ياسمين & $\varepsilon$ \\
\hline TrIA & 1 & هناء & 10 & $T r \cdot V$ & r & مروة & 0 \\
\hline r). 0 & r & علياء & 17 & 0074 & גזr & حسن & 7 \\
\hline 190. & rrv & سعيد & IV & $0 \leqslant T V$ & 1 & حسام & v \\
\hline INTE & orq & سيد & 11 & rᄉro & 1 & ولاء & $\wedge$ \\
\hline 1790 & iv & حسناء & 19 & $r \leqslant Y \wedge$ & $\varepsilon \leqslant r$ & حسين & 9 \\
\hline IVYT & 1 & عماد & $r$. & rirq & 1 & سلمي & 1. \\
\hline
\end{tabular}


إجابة التساؤل السابع: ما الأسماء التي ظهرت بعد موسو عة السلطان قابوس لأسماء العرب؟ بمقارنة الأسماء التي رصدتها الدراسة مع الأسماء التي وردت بموسوعة السلطان قابوس

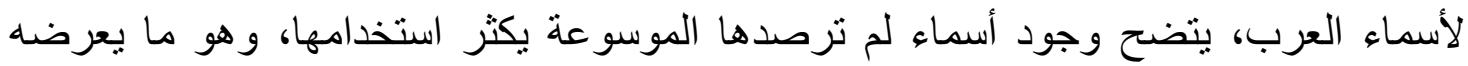

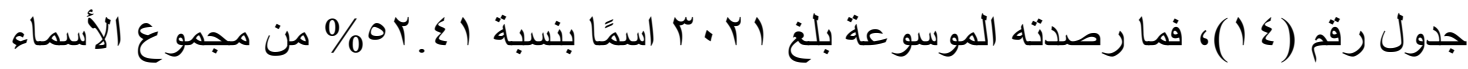
المستخدمة وبتكر ار ات بلغت

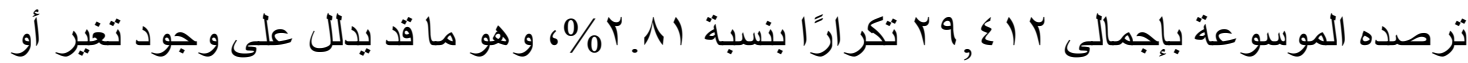

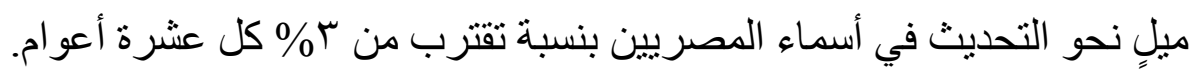
جلول رقم (ء ا ) مقارنة مع أسماء موسوعة السلطان قابوس لأسماء العرب

\begin{tabular}{|c|c|c|c|c|}
\hline$\%$ & التكرار & $\%$ & العدد العد & المقارنة \\
\hline $0 \% 9 \vee .19$ & 1.10077 & $\%$ OY. $\{1$ & $r \cdot r$ & موجود بالموسو عة \\
\hline$\%$ \% & rq६। & $\% \leqslant V .09$ & $r V \leqslant r$ & غير موجود بالموسو عة \\
\hline$\% 1 \ldots$ & $1 . \varepsilon \varepsilon q \vee \wedge$ & $\% 1 \ldots$ & OVY & المجموع \\
\hline
\end{tabular}

ومن الأسماء التى لم يرِد ذكرها في موسوعة الأسماء العمانية: كيرلس، مارينا، ابانوب،

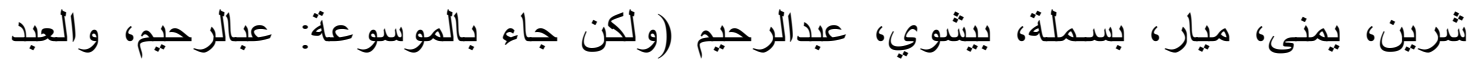

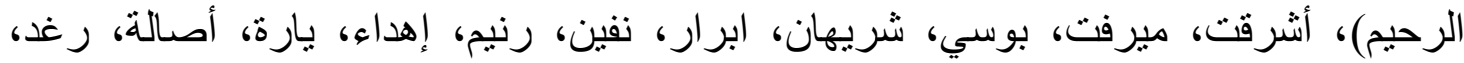

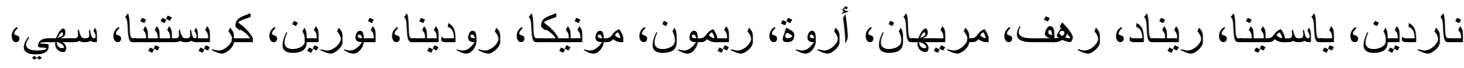

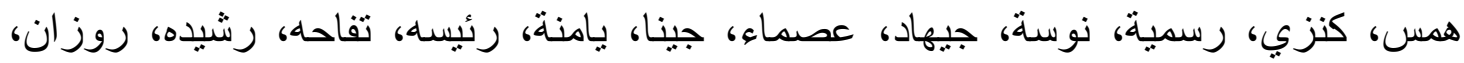

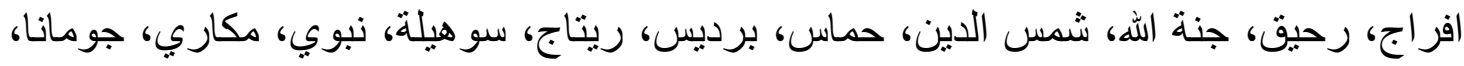

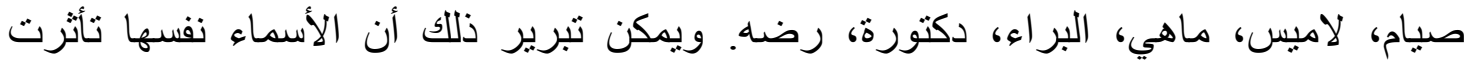
بتكنولوجيا المعلومات والاتصالات، فتحول العالم لقرية صغيرة، مما جعل استيراد الأسماء وتوليدها أكثر حركة ونشاطًا سواء من خلال الإنترنت أو السفر للخارج، حيث أتاح ذلك معرفة

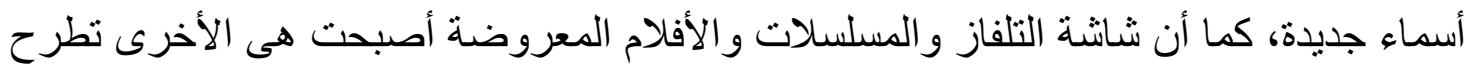

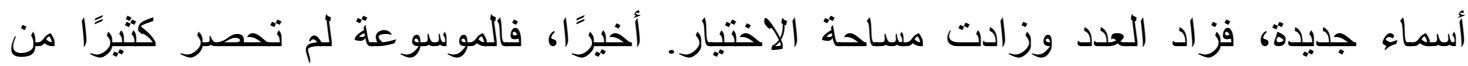

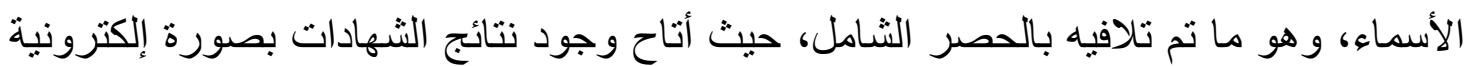

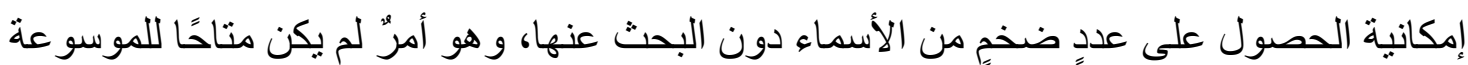

إجابة التساؤل الثامن: ما أصول ومصسادر الأسماء؟ يُعد مصدر الاسم أو معلومات أصل التسمية أحد العناصر التي تلعب دورًا فاعلً في التسمية،

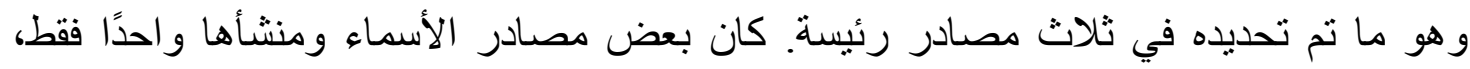


و البعض الآخر كان الاسم الواحد مستخدمًا من قبل أكثر من مصدر ، و لا يعلم ما هو أصله الحقيقى

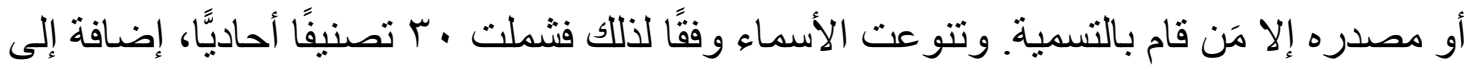
7 تصنيفات زوجية ومختلطة، يضاف لهذا المجهول، و المشترك، وما لم يتم تتناوله من أسماء. شمل الأصل الأحادى: آر امى واحد فقط (برسوم)، و إسباني واحد فقط (ماريا)، واسكتلندى (ماحى

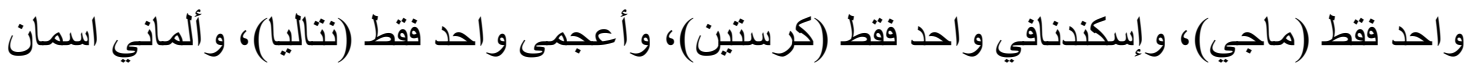

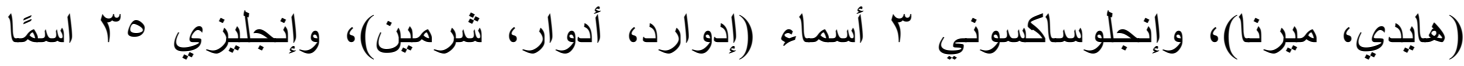

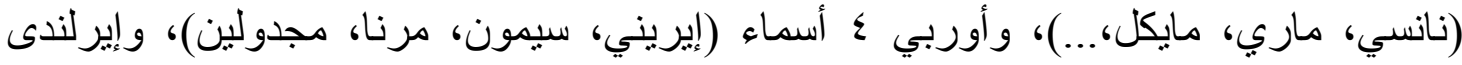

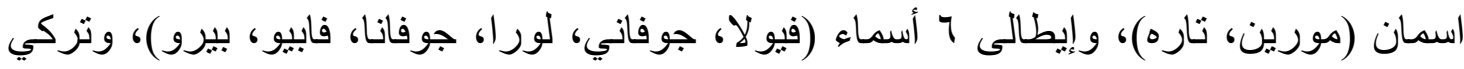

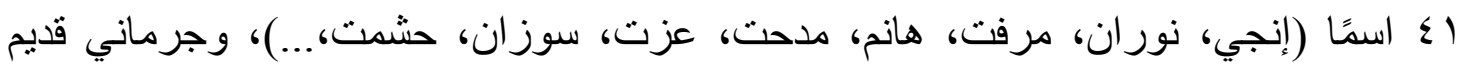
اسمان (البرت، ايدا)، وروسي V أسماء (يوستينا، راشا، لار أها، سونيا، كترينا، فاكي، ديم)،

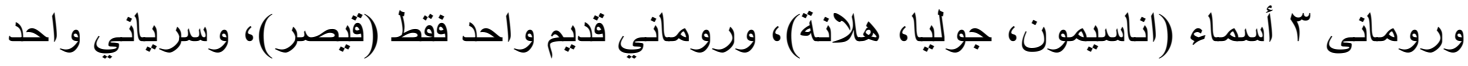
فقط (نيسان)، وسنسكريتى اسمين (لاما، فلفل)، وسو احيلى و احد فقط (اديان)، و عامية مصرية ورية ماني

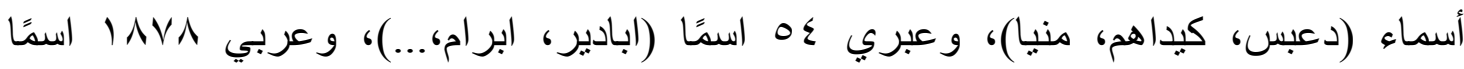

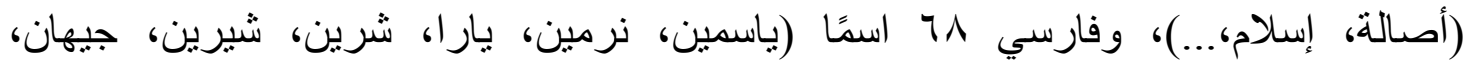

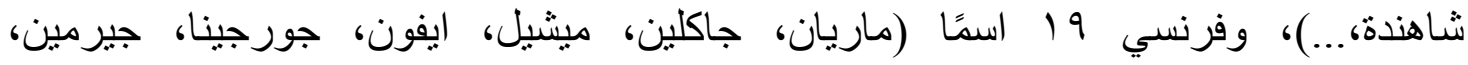

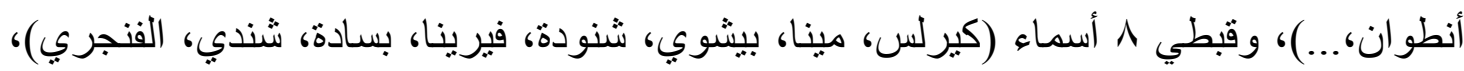

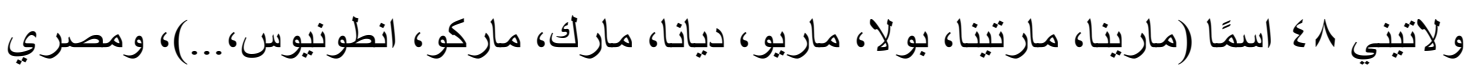
قديم 7 أسماء (بسنت، باخوم، ايزيس، الشوادفي، رمسيس، بانوب)، و هندى واحد فقط (غاندي)،

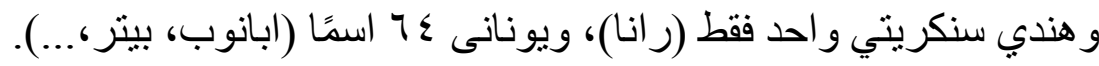

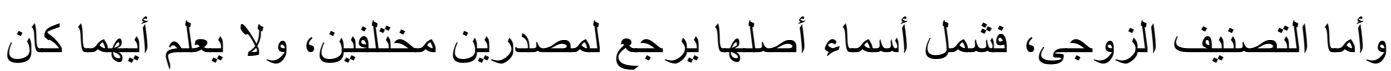
المراد من التسمية، وشملت: آرامي وعبري و احد فقط (توماس)، وسرياني وعبري واحد فقط وهاء

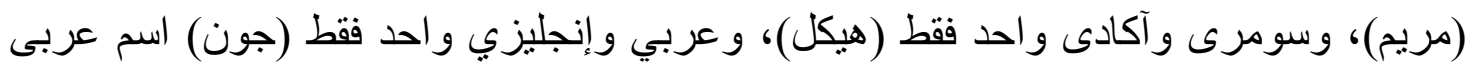

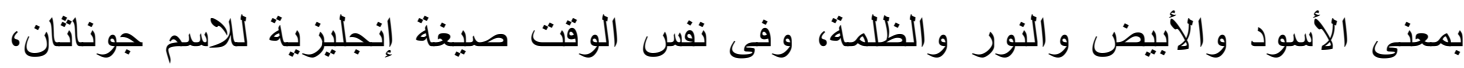
و الاستخدام الغالب هو للاسم الإنجليزى للجهل بمعنى الاسم العربى، و عربي و عبري اسم واحد

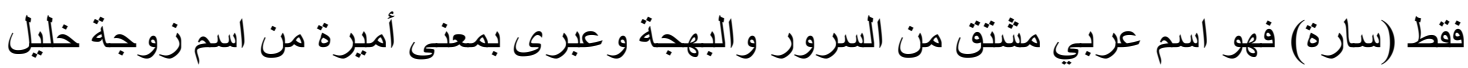

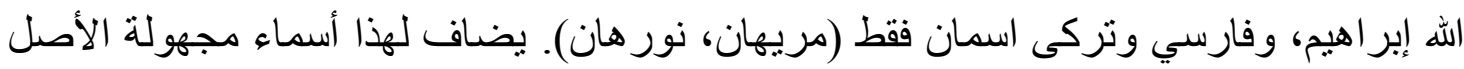

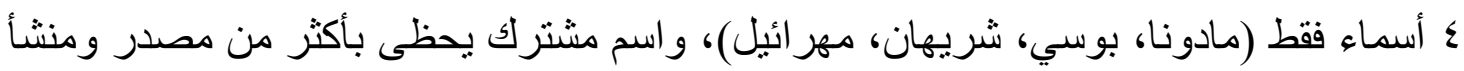

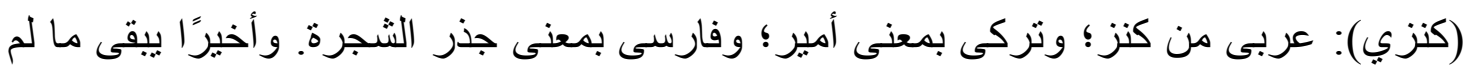

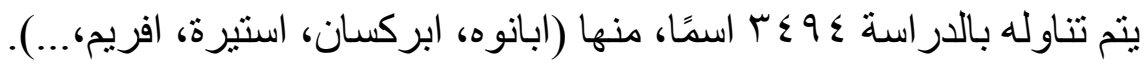

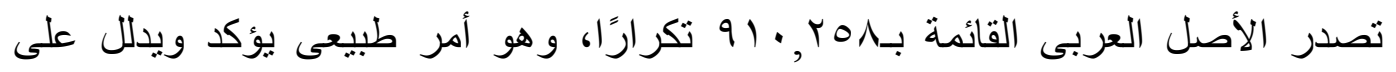

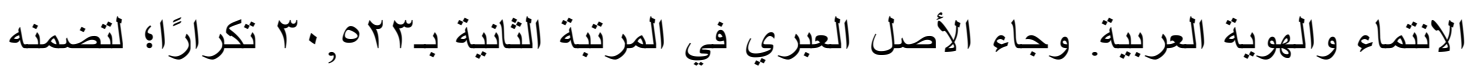


أسماء أنبياء ذكر هم القرآن الكريم وهم: إبر اهيم، ويوسف، و إسماعيل، وموسى، وزكريا، ويونس.

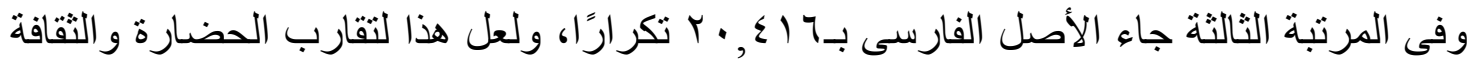

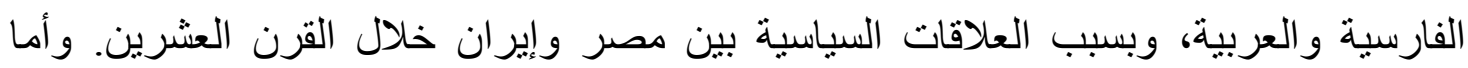

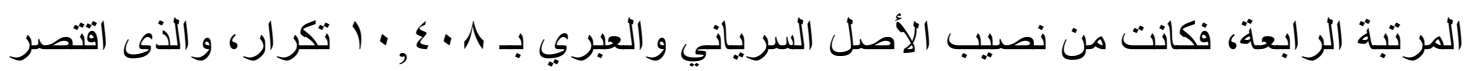

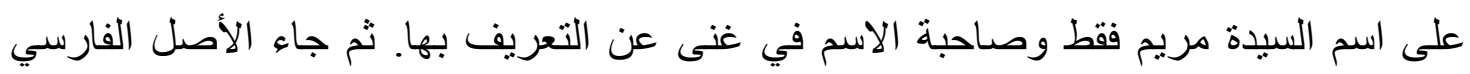

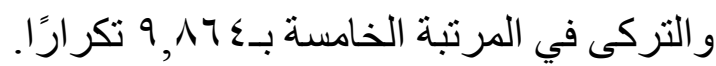

إجابة التساؤل التاسع: ما التصنيفات الموضو عية الأكثر شيو عًا في التسمية؟

لم يترك المصريون موضوعًا إلا و استخرجو ا منه أسماء لأبنائهم، وباستثناء ما لم يتم تصنيفه من الأسماء فقد تم توزيع الأسماء إلى لى لفئة شملت كل نواحى الحياة ومجالاتها من: أنبياء، ودين

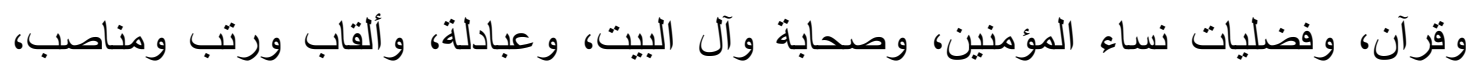

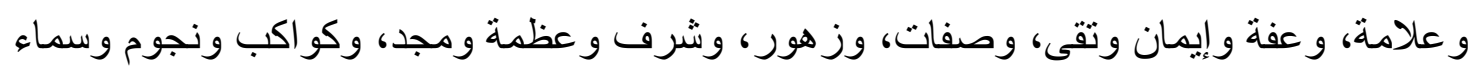

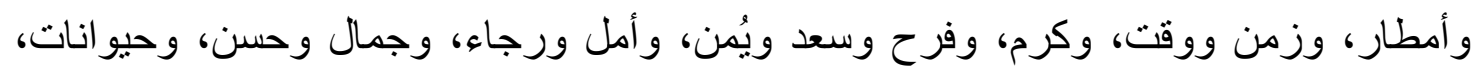
وقوة وشجاعة وقدرة و عظمة، وحب ومودة وشوق و عشق، ودعاء ونداء واستغاثة... الخ. تظهر المشكلة في تصنيف الأسماء في عدم وضوح المعنى لدى القائم بالتسمية، فربما يكون

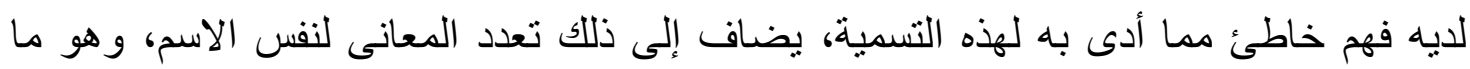
فرض استخدام المعنى الأكثر شيو عًا واستخدامًا، وهو ما يظهر في الأمثلة التالية: هند (اسم دولة، لهئ واسم لحيوان و الغالب اسم الدولة)، وتم ترجيح التسمية الأغلب.

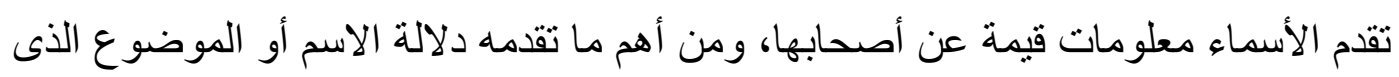

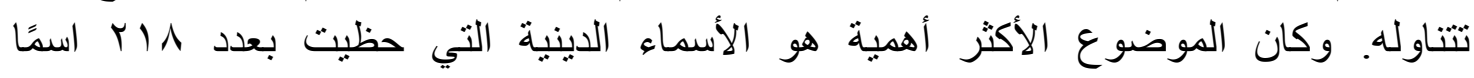

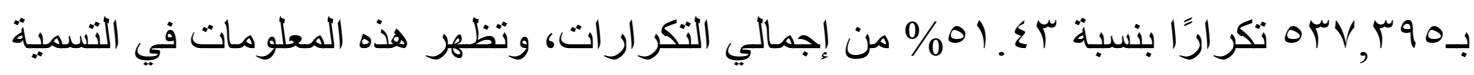

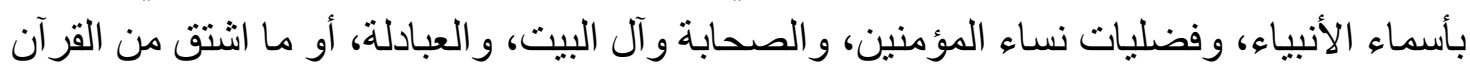

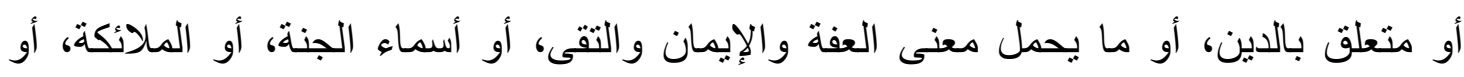

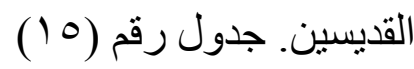


جدول رقم (0 10 ) فئات موضوعات الأسماء

\begin{tabular}{|c|c|}
\hline فئات موضوعات الأسماء & 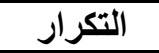 \\
\hline أنبياء & rTAOVT \\
\hline قر آني وديني & $9 \vee \leqslant 97$ \\
\hline فضليات نساء المؤمنين & $7 \varepsilon \uparrow \wedge \varepsilon$ \\
\hline صحابة و آل البيت، عبادلة، ألقاب ورتب ومناصب، متنو عات، علامة، عفة و إيمان وتقى & $\begin{array}{l}-r \ldots 1 \\
0 \ldots\end{array}$ \\
\hline 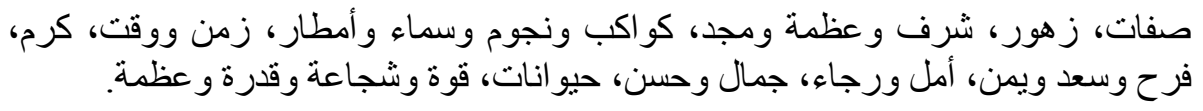 & $\begin{array}{l}-1 \cdots+ \\
r \cdots\end{array}$ \\
\hline 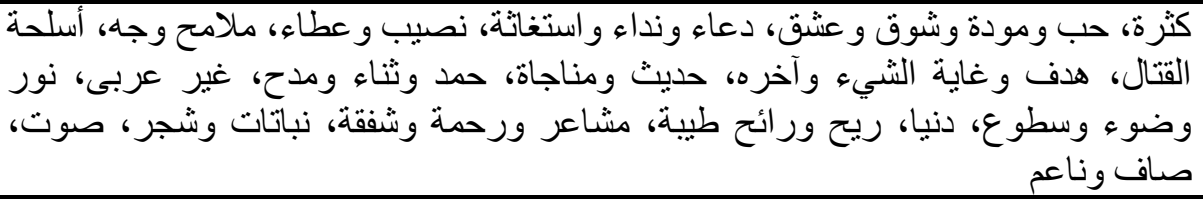 & $-0 \cdots 1$ \\
\hline 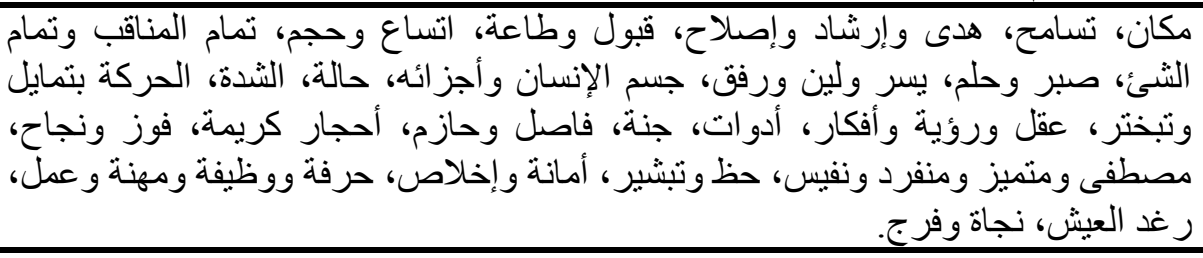 & \\
\hline قديسينكة، ألو اني، نوع منية، التسبية، بالجملة، جديد، تليل وتمليح، مظاهر طبيعية وجغر افية، نسبة إلى، & $1 \ldots-1$ \\
\hline
\end{tabular}

تصدر اسم محمد قائمة الأنبياء، تلاه اسم أحمد، ثم اسم محمود فاسم مصطفى، وبلغ عدد

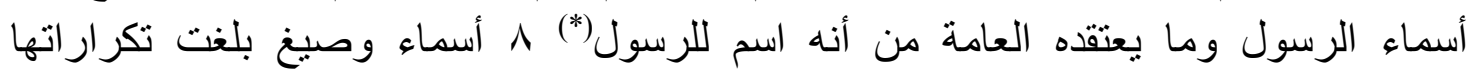

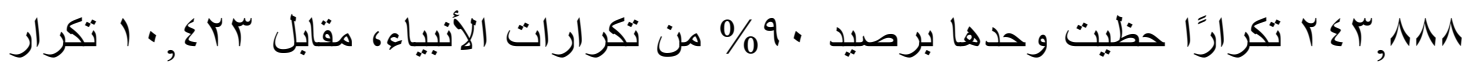

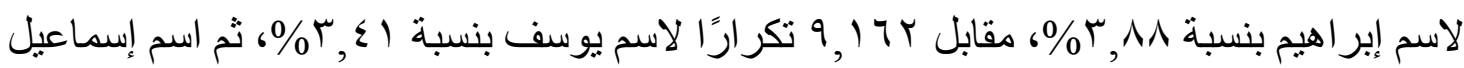

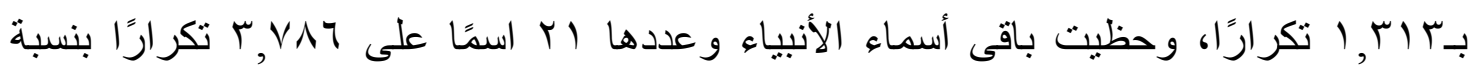

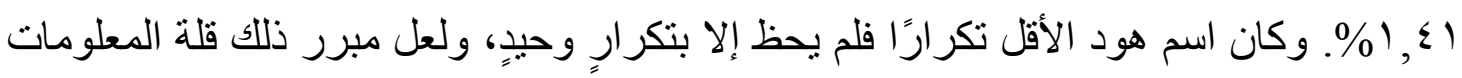

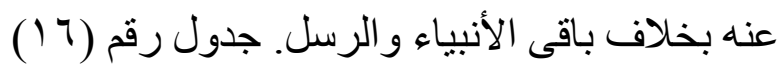

(*) طه: حروف مقطعة فهم أنها اسم لرسول الله، ياسين: لم برد نأكيدا أنه من أسماء النبي. 
جدول رقم (7 ا ) أسماء الرسول

\begin{tabular}{|c|c|c|c|c|c|}
\hline$\% q \cdot . \wedge 1$ & $r \leqslant r \wedge \wedge \wedge$ & أسماء الرسل & $\%$ & التكرار & أسماء الرسول محمد \\
\hline$\%\ulcorner. \wedge \wedge$ & $1 \cdot \sum r T$ & ابر اهيم & $\% \leqslant r . \leqslant r$ & 1.09r & محمد \\
\hline$\%$ \%.\&1 & 9174 & يوسف & $\%$ \%r. 9 & $\lambda \cdot V 11$ & احمد \\
\hline$\% \cdot . \leqslant 9$ & $1 \pi 1 \pi$ & اسماعيل & $\% 1 \leq .90$ & rTIOO & محمود \\
\hline$\% 1 . \varepsilon 1$ & rVA & باقى الأنبياء & $\% 0^{\vee} .79$ & INVOr & مصطفي \\
\hline \multirow[t]{5}{*}{$\% 1 \ldots$} & rYAOVY & مجموع الأنبياء & $\% \cdot .7 T$ & 1041 & طه \\
\hline & & & $\% \cdot .17$ & $\varepsilon \ldots$ & ياسين \\
\hline & & & $\% \cdot \cdot \cdot r$ & TV & 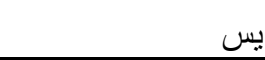 \\
\hline & & & $\% \cdot \cdot \cdot r$ & or & يسن \\
\hline & & & $\% 1 \ldots$ & $r \leq r \wedge \wedge \Lambda$ & \\
\hline
\end{tabular}

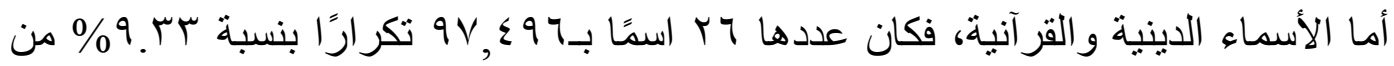
تكرارات الأسماء. وتصدر القائمة اسم آية بـ

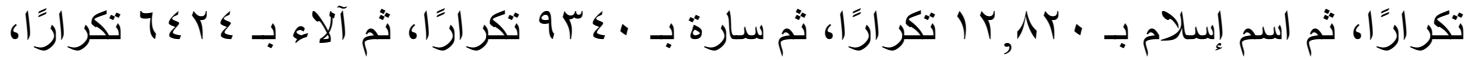

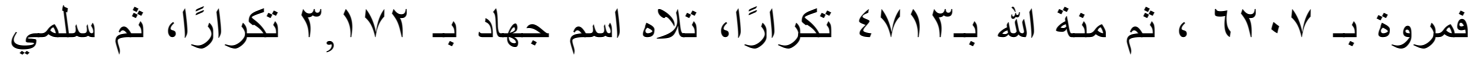

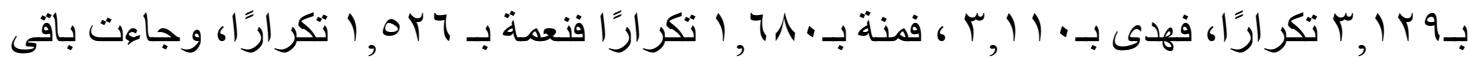
الأسماء برصيد أقل من · . . 1 تكرار: آيات، رقية، بسملة، بدر، سندس، طاهر، ابرار، ابتهال،

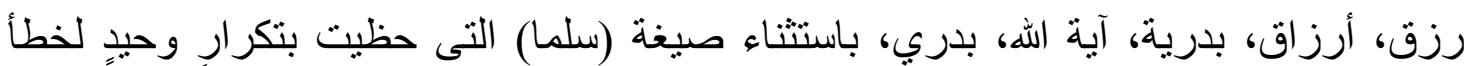
التسجيل و عدم المعرفة بالألف اللينة. لبه.

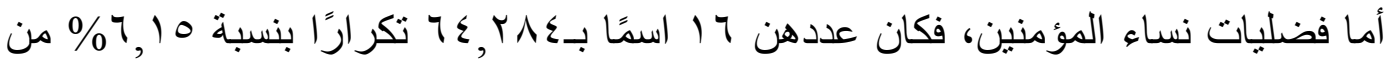

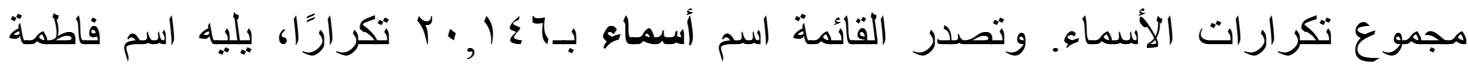

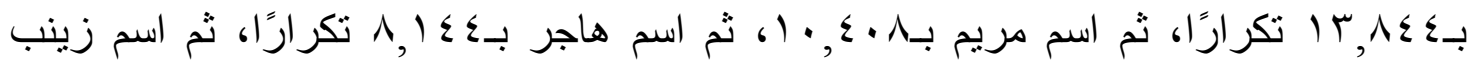

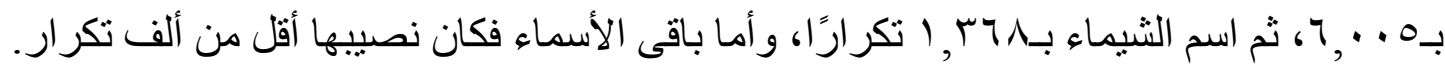

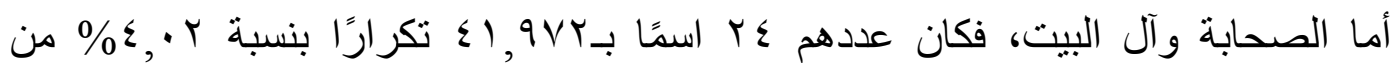

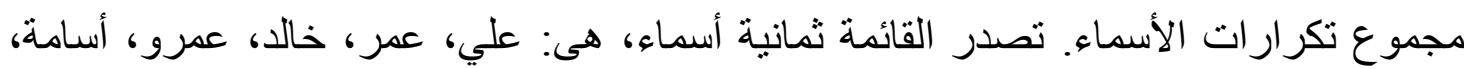

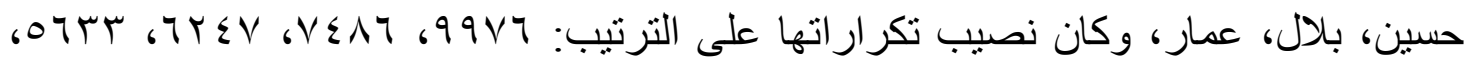

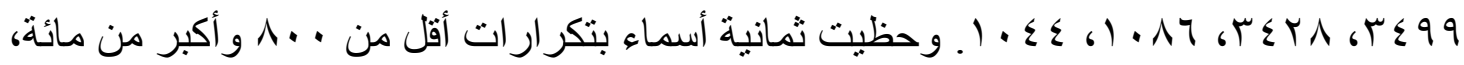

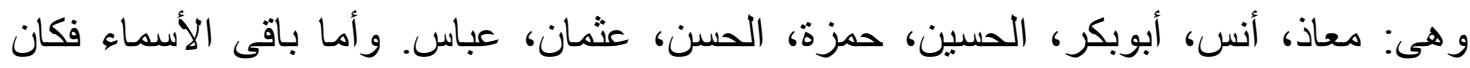

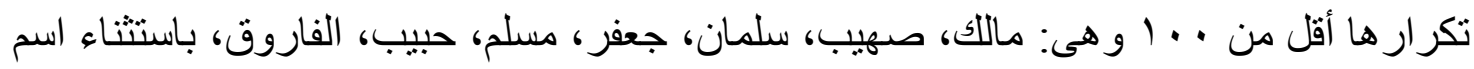


(أويس) الذى حظى بتكر ارٍ وحيدٍ فقط لندرة المعلومات عنه.

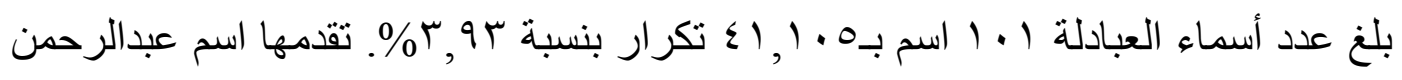

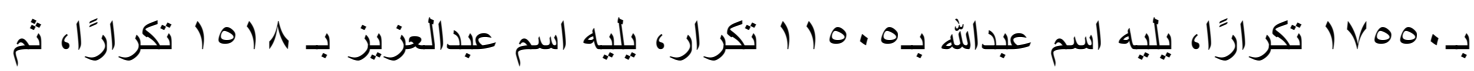

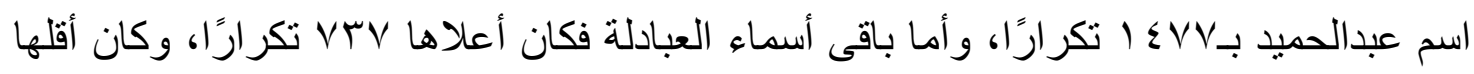

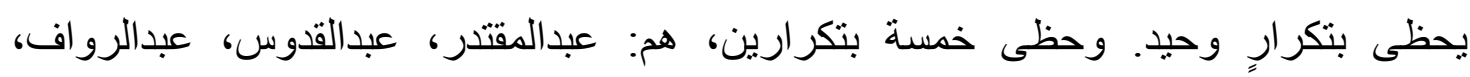

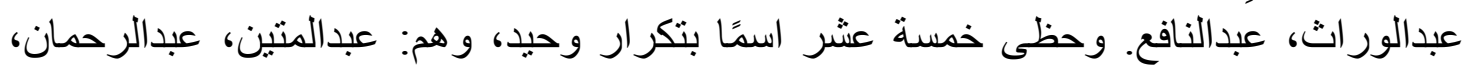

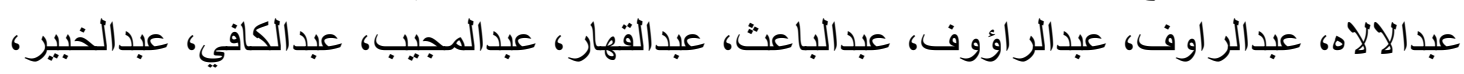

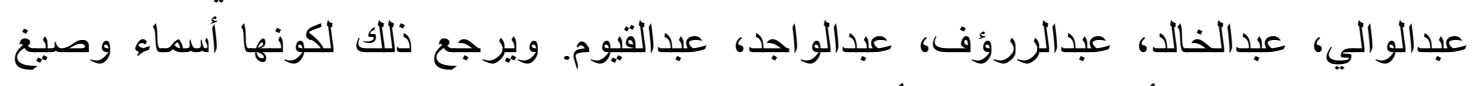
كتابية غير معروفة، أو غير منتشرة، أو غير صحيرة صحيحة. وتنو عت تصنيفات الأسماء(*): فثملت متنوعات متفرقة (ندا، و لاء، شهد، ريهام)، و علامة

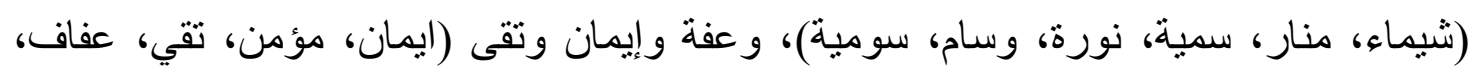

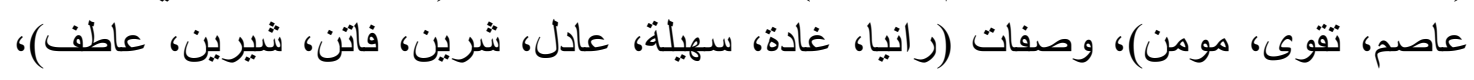

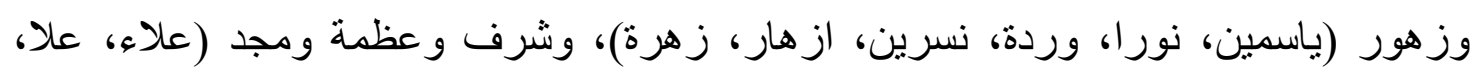

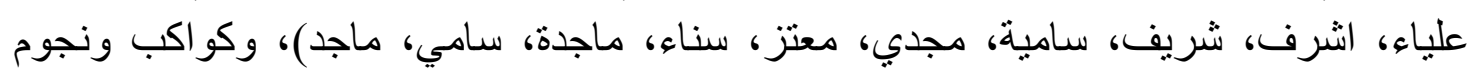

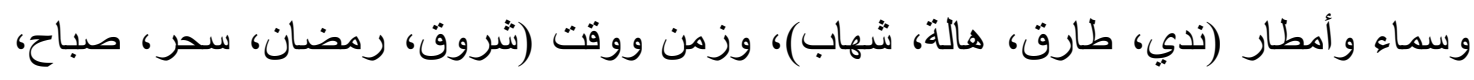

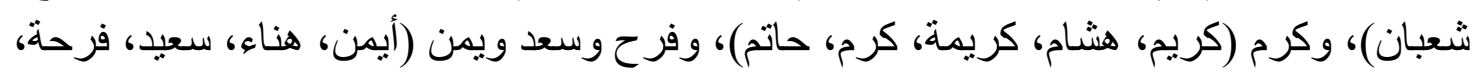

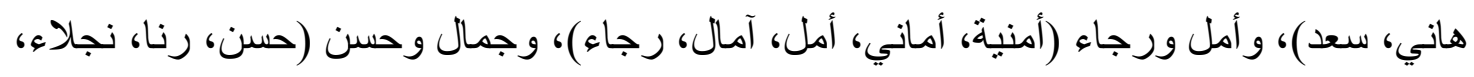

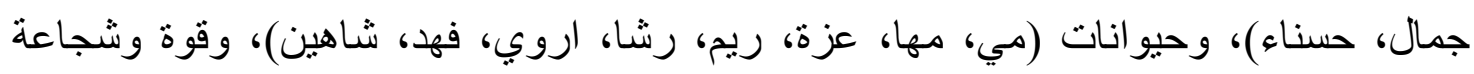

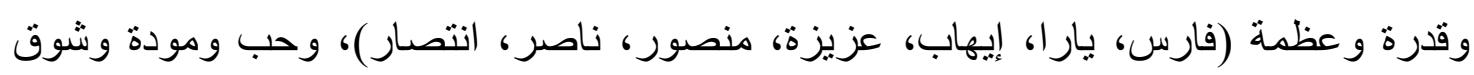

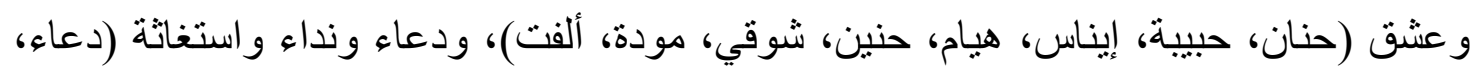

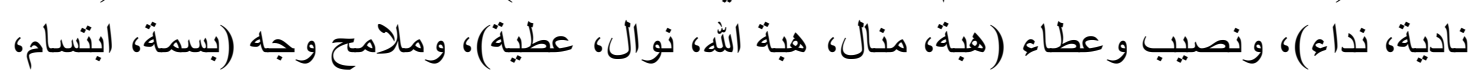

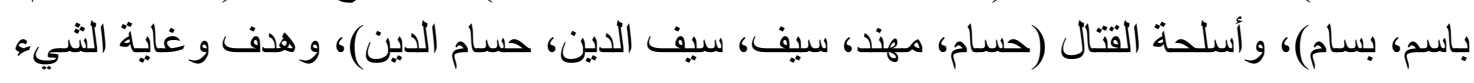
وآخره (مني، نهي، نها، مرام)، وحديث ومناجاة (سمر، نجوي، سميرة، سمير)، وحمد وثناء

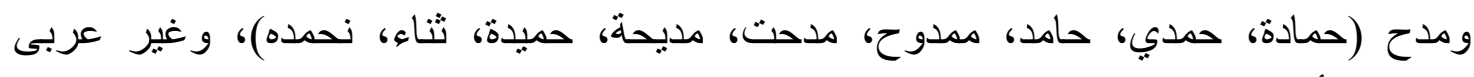

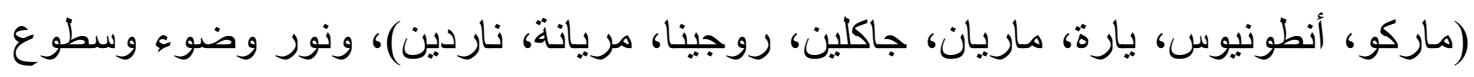

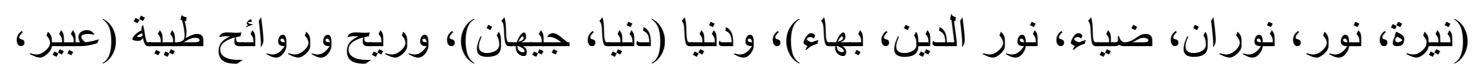

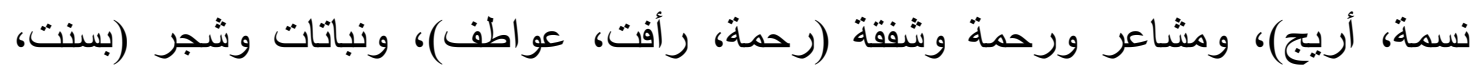

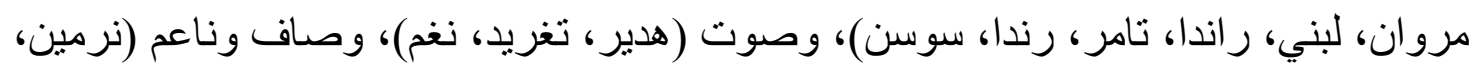
صفاء، نيرمين)، ومكان (هند، روماني، عرفة، صفا، زمزم، عرفان، ونات، دارين، اسيا، سوريا،

(*) تعرض الدر اسة لنماذج من الأسماء داخل كل تصنيف وليس لكل الأسماء الواردة فيه وفقًا للأكثر تكرارًا. 


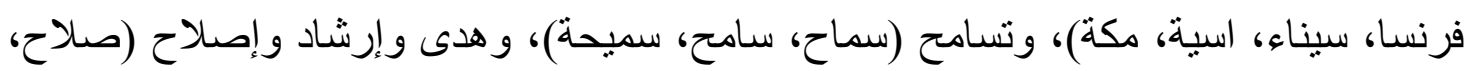

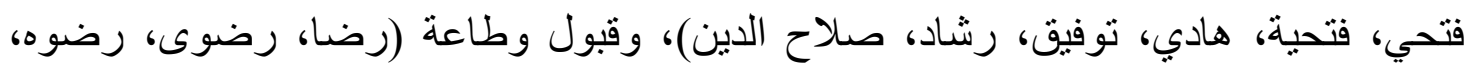

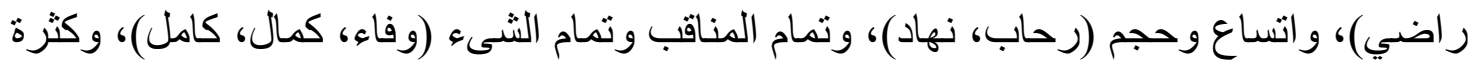

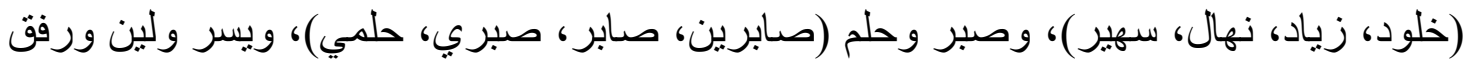

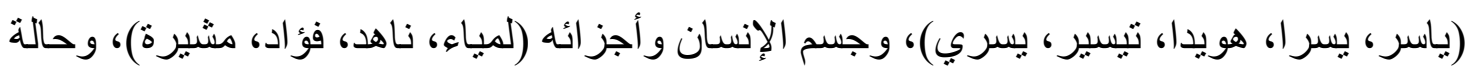

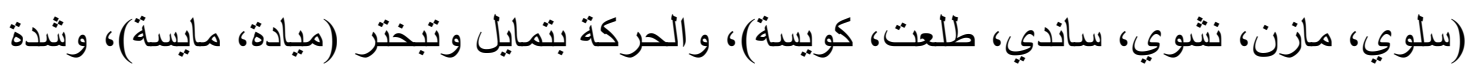

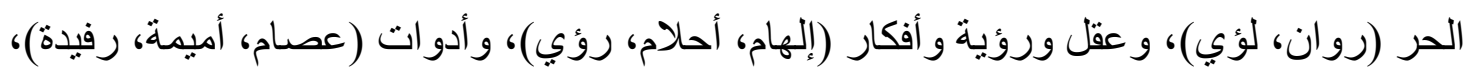

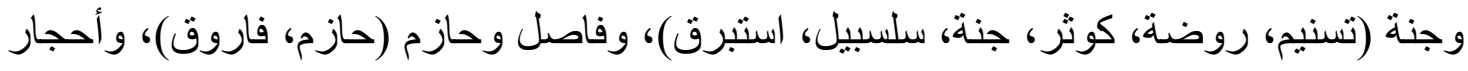

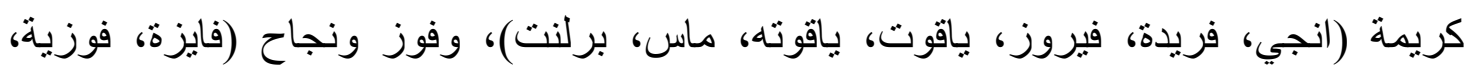

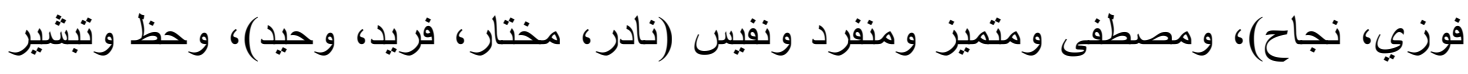

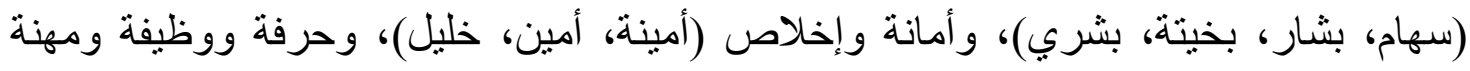

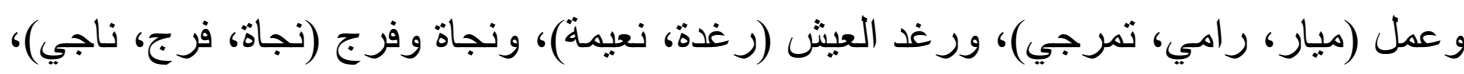

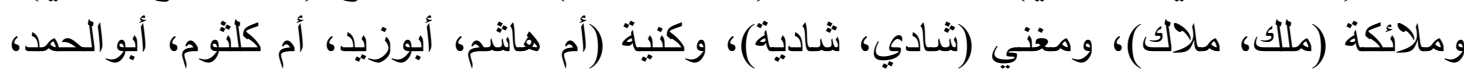

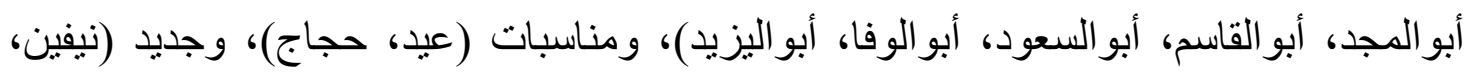

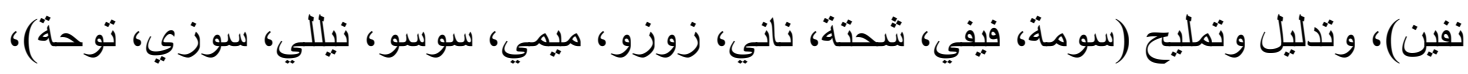

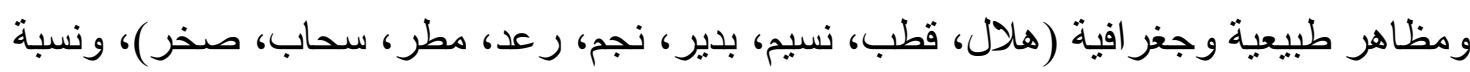

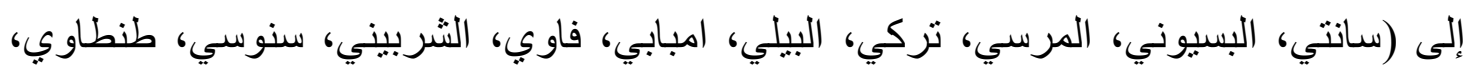

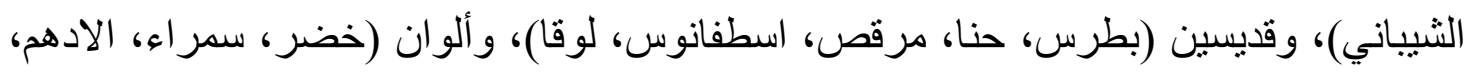

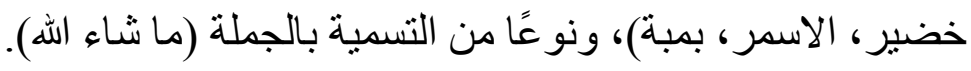

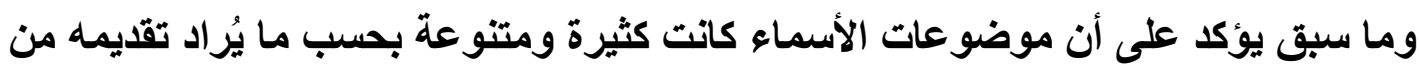

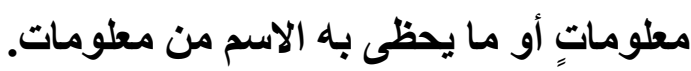

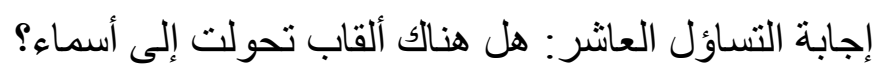

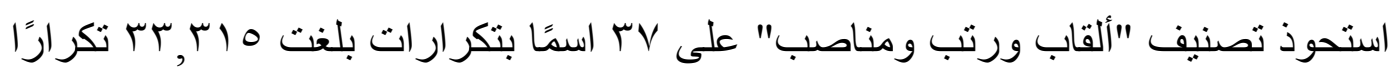

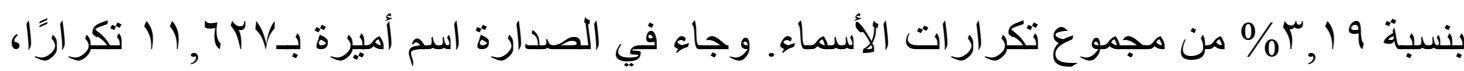

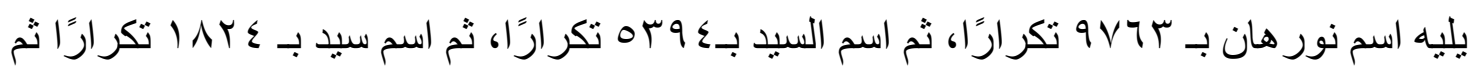

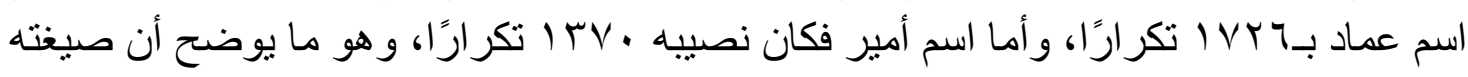

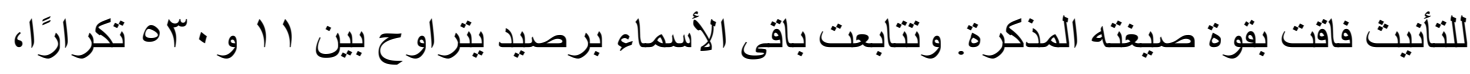

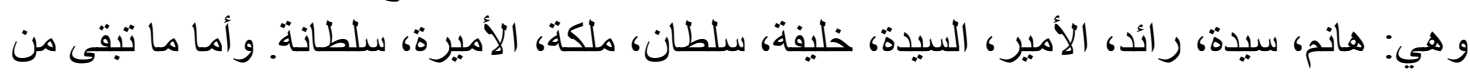

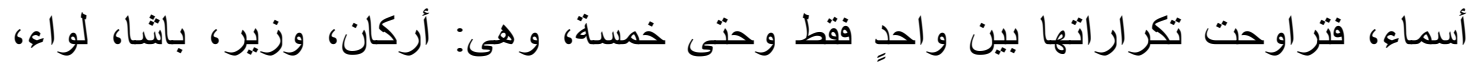

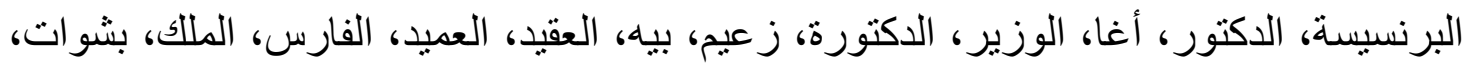


وزيره، رئيس، مقدم، ملازم، برنسس.

وهو ما يؤكد أن هنايك ألقابًا ورتبًا ومناصبَ تحولت إلى أسماء، وإن جاءت بنسبٍ وأعدادٍ مثفاونة.

إجابة التساؤل الحادى عشر : ما الجذور الأكثر شيوعًا في التسمية؟ اقتصرت معالجة الجذر على الأسماء العربية الأصل، وتم استبعاد ما ليس له جذر أو ما

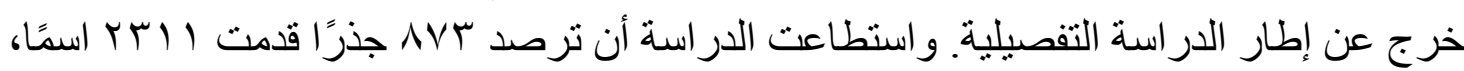
وأظهرت الدراسة وجود تنوع هائل في الأسماء؛ نتيجة لاستثمار إمكانات اللغة العربية

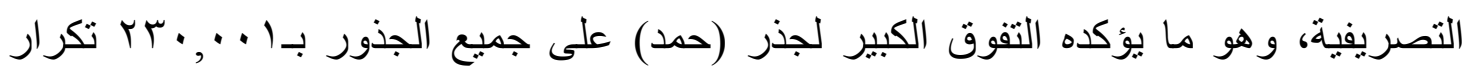

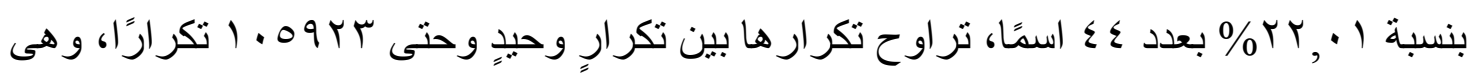

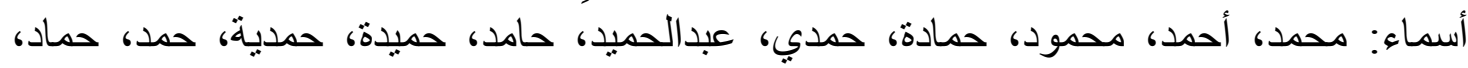

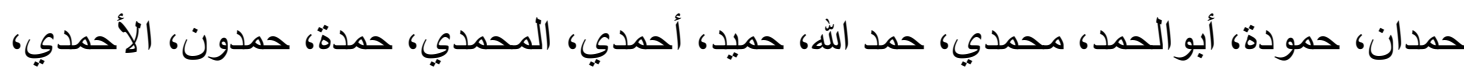

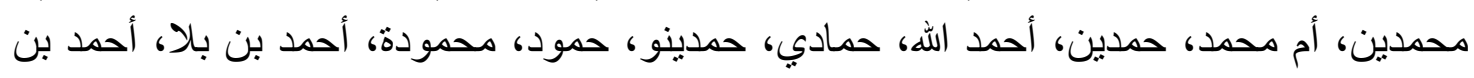
بيلا، محمدية، الحامدي، محمد الأمين، حمدته، حامده، حمدتو، حامديه، حمدات، أبوالحمايد، حمدناه، محمودي، حميدان. ولعل صدارة هذا الجذر يرجع لوجود اسم الرسول به، إضافة لكونه يخص صفة الحمد.

وحظى جذر (سعد) بالمرتبة الثانية في عدد الأسماء التى اشتقت منه، حيث بلغت 9 ب اسمًا

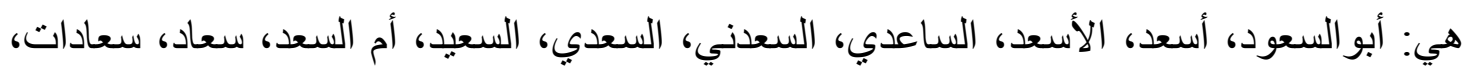

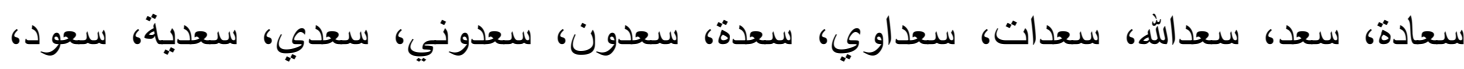

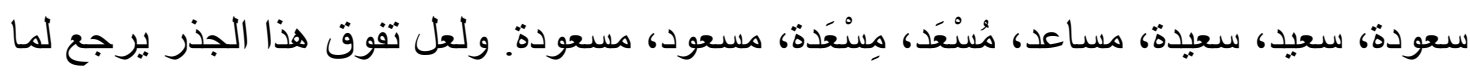

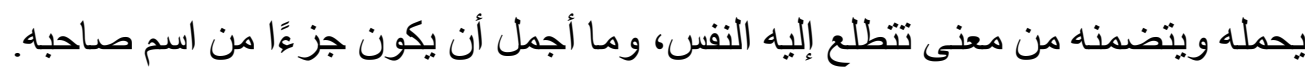
وجاء جذر (أيي) في المرتبة الثانية في التكرارات الأعلى بثلاثة أسماء، هى: آية، وآيات،

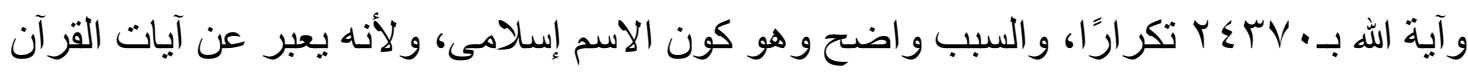

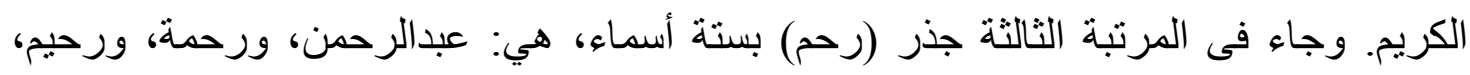

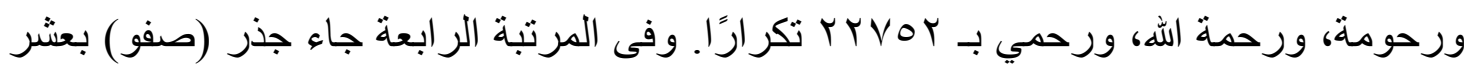

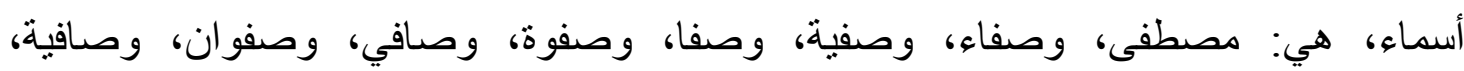

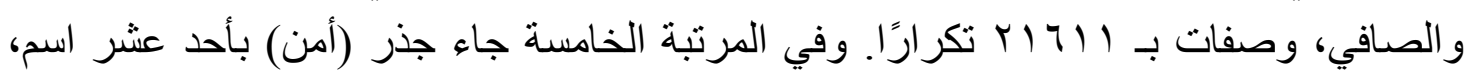

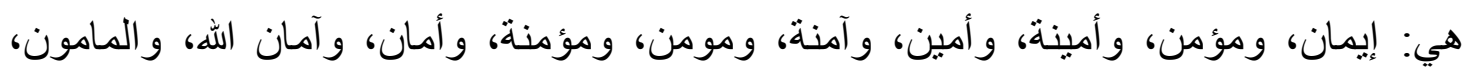

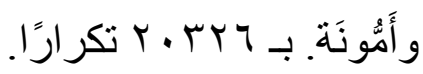




\section{وهو ما يظهر الميل ناحية الجذور التى تدل على دلالات ومعان حميدة وذات توجه دينى.}

إجابة التساؤل الثانى عثر: ما الصيخ الصرفية الأكثر شيوعًا في التسمية؟

اقتصرت معالجة الصيغ والأوزان على الأسماء العربية الأصل، مع استبعاد ما لا يوجد له

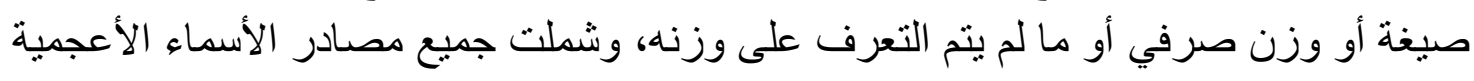
وحتى بعض الأسماء العربية، يضاف لذللك ما يخرج عن الدراسة وهى هـ أسماء تدخل في النسبة

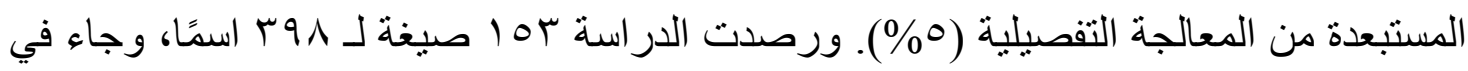

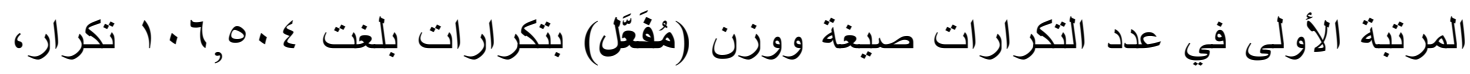
شملت أسماء: محمد، مهند. وترجع صدارتها لأنها اسم مفعول مصوغ غون ليدل على مَن وقع عليه فعل الفاعل، وترتبط بالمبالغة في الفعل، وهى من المعلومات المرغوبة في الأسماء. وفى المرتبة

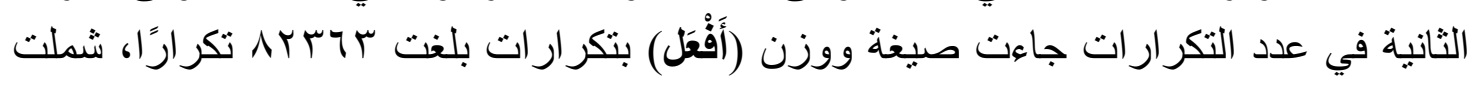

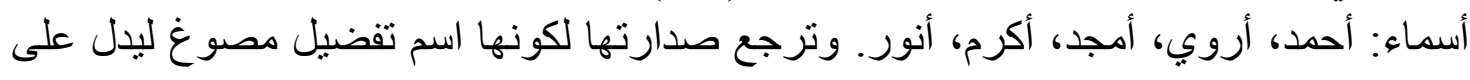
زيادة الموصوف على غيره في الفعل المشتق منه، وهى معلومات مرغن غوبة بشدة في الأسماء.

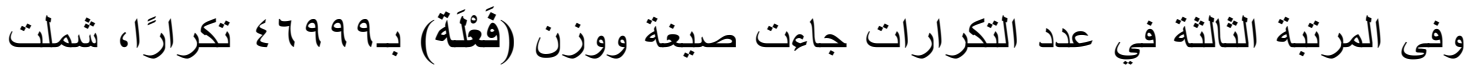

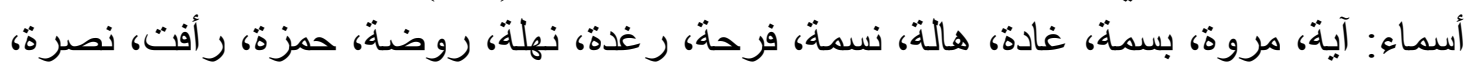

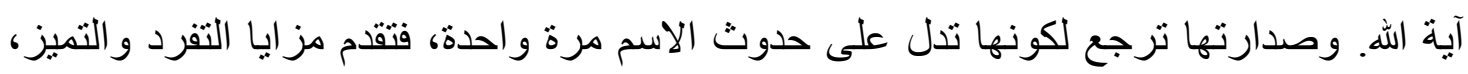
وهى أيضًا من المعلومات المطلوبة في الأسماء.

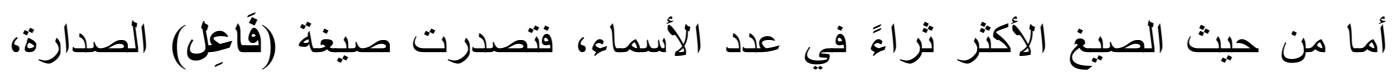

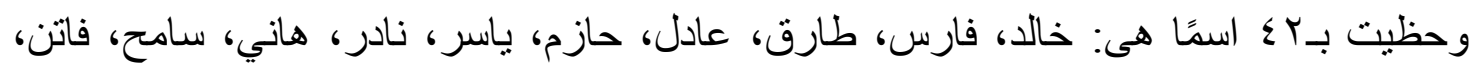

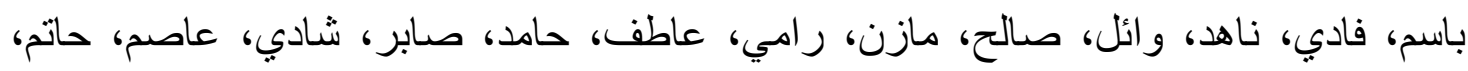

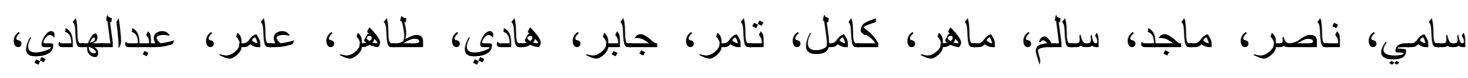

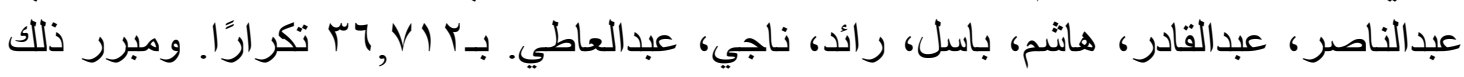

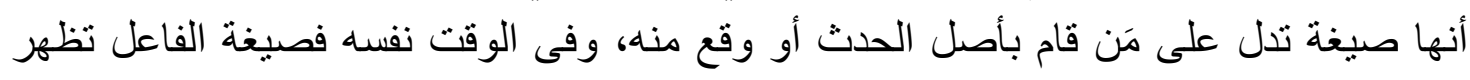

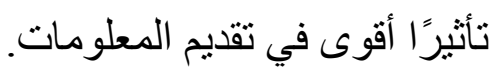

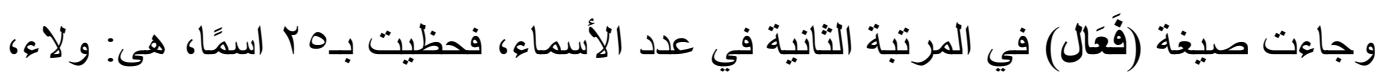

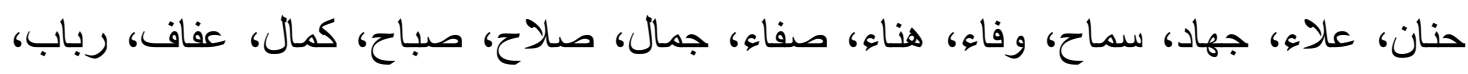

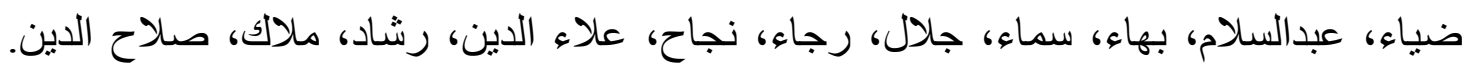

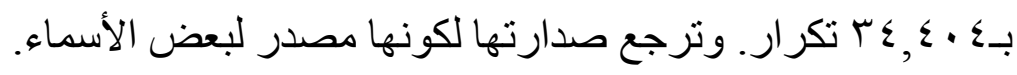


إجابة التساؤل الثالث عثر : ما الأسماء المُستحدَثة في التسمية؟ تتوعت الأسماء الموجودة بين عربية الأصل وعربية تم استحداثها أو غير عربية أو تم

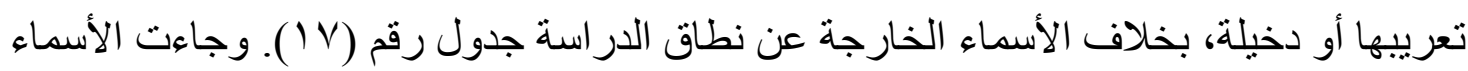

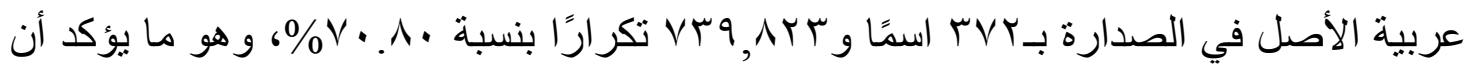
اللغة العربية لا تزال هى الأصل في تسمية أسماء المصريين. وفى المرتبة الثانية جاءت الأسماء

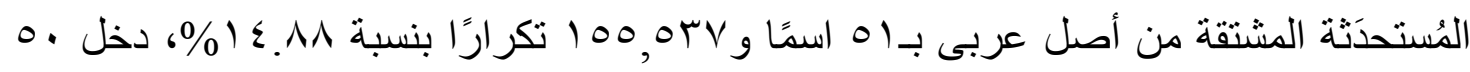
اسمًا منها قائمة الدر اسة، ولم يُستبعَد سوى اسم واحد فقط هو اسم أشرفت الذى حظى بتكر ارٍِّ و واحد فقط. و هو ما يعنى أن التطور و التغير قد شمل الأسماء نفسها.

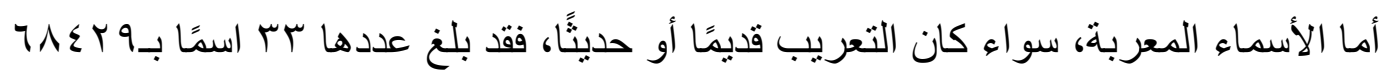

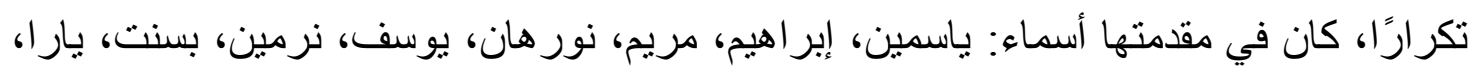

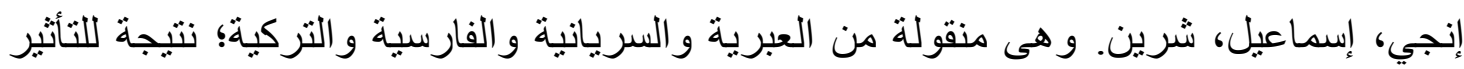
الدينى وللاختلاط بين هذه الثقافات و امتز اجها بالثقافة العربية.

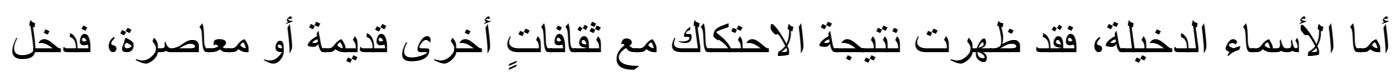

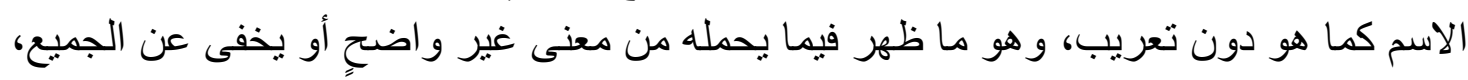

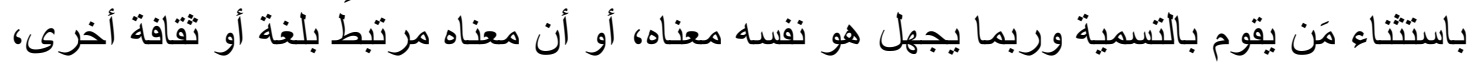

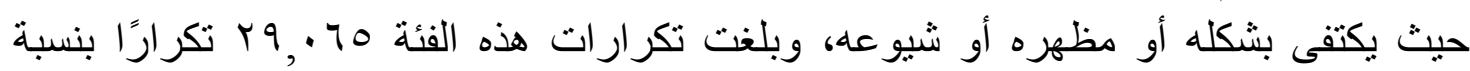

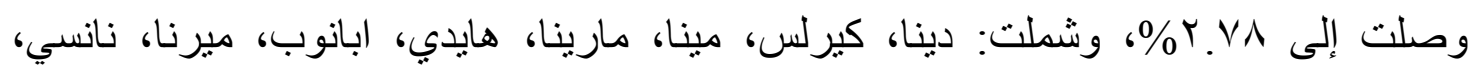
بيشوي، دِمْيانة، ماري، يَسَّى...

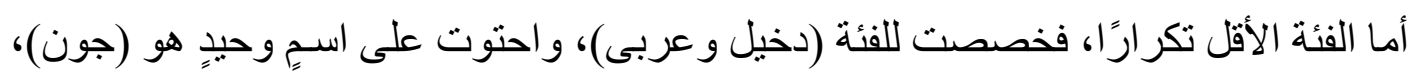
وقد سبق تناوله عند عرض أصول ومصادر الأسماء داخل التصنيف الزوجى. جدول رقم (IV) جدول استحداث الاسم

\begin{tabular}{|c|c|c|}
\hline$\%$ & التكرار & استحداث الاسم \\
\hline$\% \vee \cdot \wedge$. & VRqArr & عربى \\
\hline$\% \backslash \varepsilon . \wedge \wedge$ & $1000 \mathrm{rV}$ & مستحدث \\
\hline$\% 7.00$ & $7 \wedge \varepsilon Y q$ & معرب \\
\hline$\%$ \%.VA & $r 9.70$ & دخيل \\
\hline$\% \cdot .1$ & $1 \leq 1$ & دخيل/ عربى \\
\hline$\% \varepsilon .9 V$ & 01911 & خار ج نطاق الدراسة \\
\hline$\% 1 \ldots$ & $1 . \leq \varepsilon q \vee \wedge$ & المجموع \\
\hline
\end{tabular}


بذلك تكون الاراسة قد استطاعت أن تجيب عن جميع التشاؤلات المطروحة، وأن تتعرف على طبيعة أسماء المصريين المعاصرة وخصائصها، وأن تتوصل إلى مختلف المعلومات التي

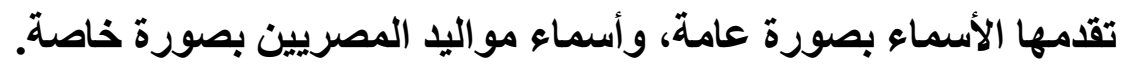
خامسًا ـ توصيات الدراسة:

يقول ابن خلدون في عنوان الفصل الثالث و العشرين من كتابه الثهير "العبر وديوان المبتدأ و الخبر في أيام العرب و العجم و البربر ومن عاصر هم من ذوى السلطان الأكبر " الثهير بـ"تاريخ

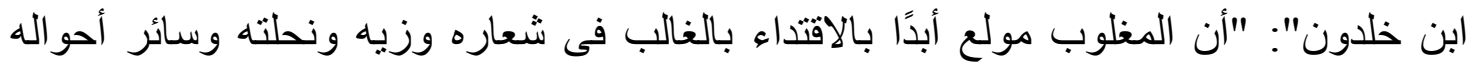

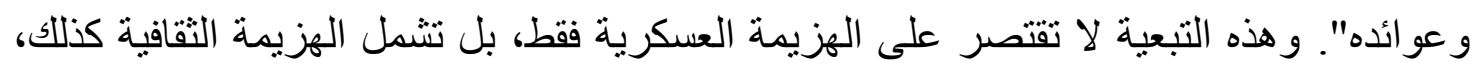

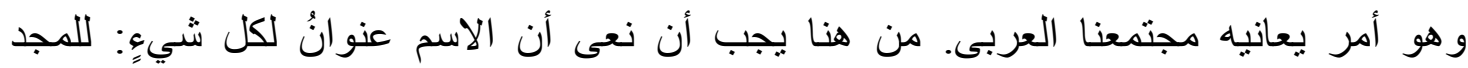

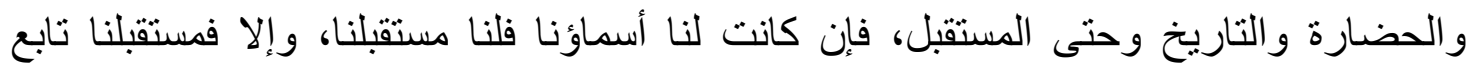

ل مستقبل غيرنا.

وحتى تحقق الدراسة قيمتها ودورها العلمى فهى تقدم التوصيات التالية: (1) (إتاحة قو ائم سنوية من مصلحة السجل المدنى بتكرارات أسماء المواليد والآباء و الأجداد تساعد فى دراسات وخدمات المعلومات المتعلقة بالضبط الاستنادى و الاسترجاع و والتنقيب في بئكي البيانات.

(Y) كثير من الناس يختارون الاسم إعجابًا به لمجرد سماعه أو لكونه جديدًا دون أن تدرك معناه

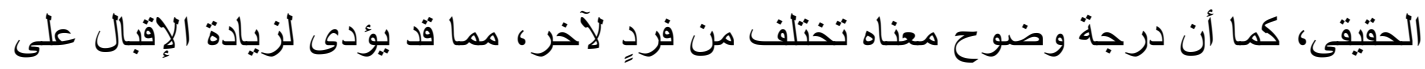

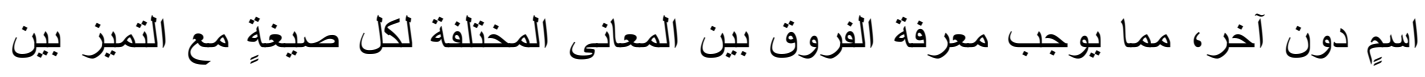
الصحيح منها والخطأ؛ فالإعجاب وحده غير كافٍ دون الإلمام بكل المعلومات الصحيحة و الدقيقة والموثقة عن الاسم. وهذا يوجب ضرورة توعية المواطنين بأن تكون الأسماء

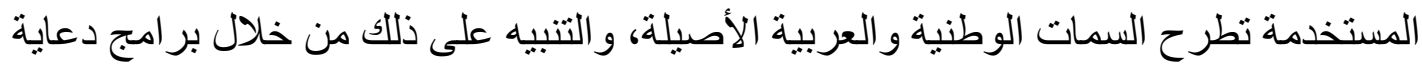

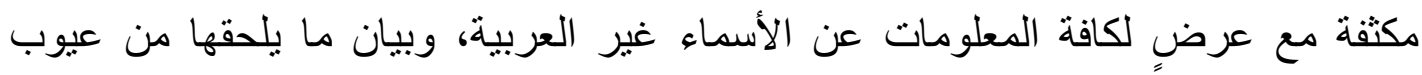

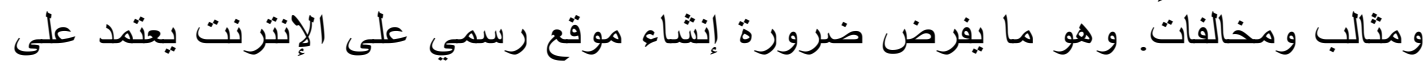

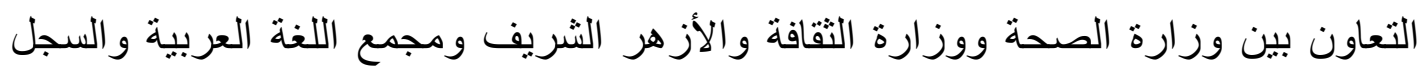

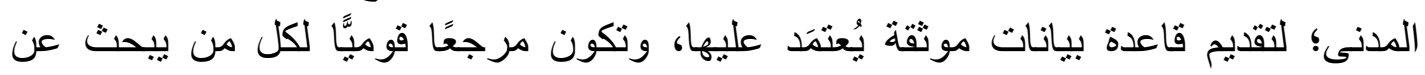

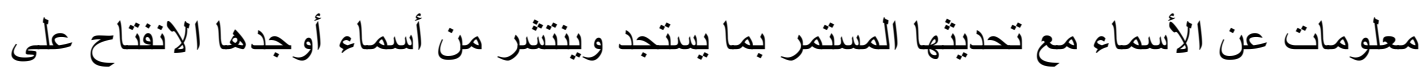

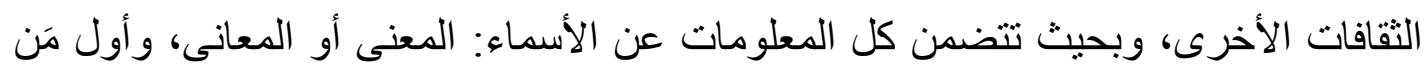

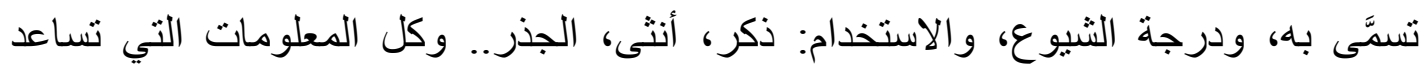

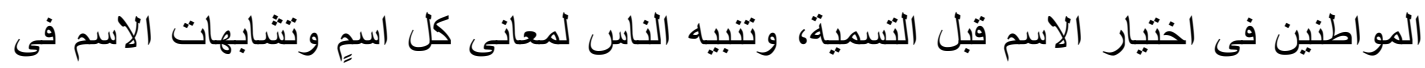
المجتمعات المختلفة، والفروق بين كل اسم. ويمكن أيضًا التوسع في إتاحة المعلومات لتكون 
متاحة لكل الناس، من خلال تطبيقاتٍ مجانية على الهاتف المحمول؛ لتبسر عليهم معرفة ما لئها

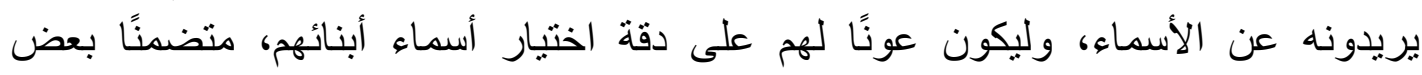

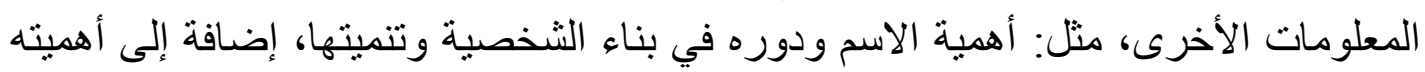

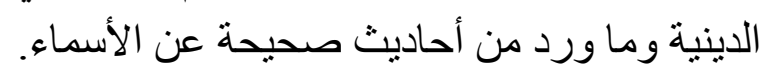

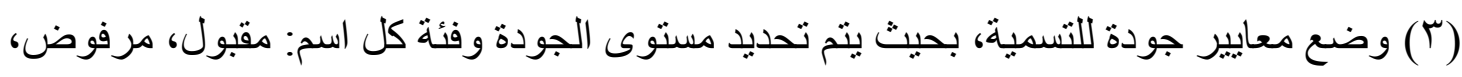
صحيح، شرعى، غير شر عى، معروف، مجهول، وفقاً للعناصر التالية:

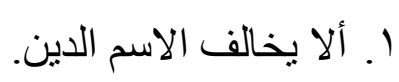

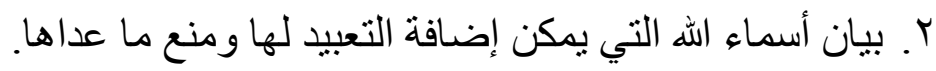

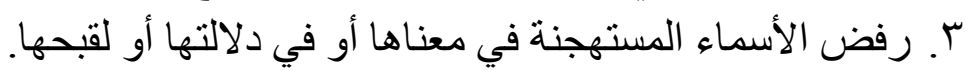
ع. يفضل ألا يطلق لفظ (عبد) منفردًا. ○. عدم إهمال استخدام الهمزة و المد في الألف، و عدم استخدام الهاء بديلًا عن التاء المربوطة.

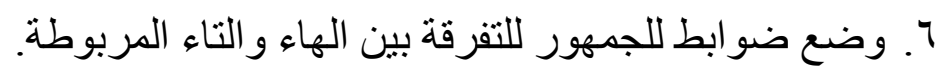

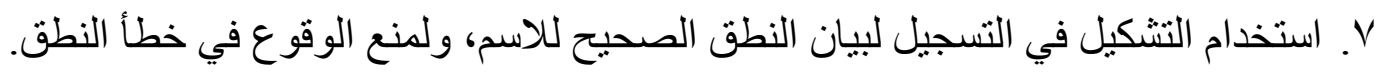

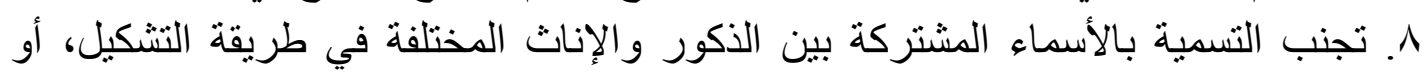

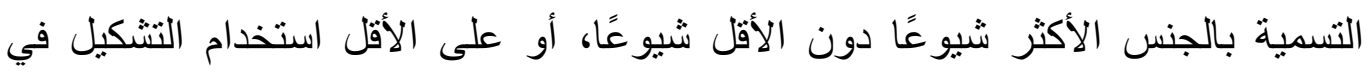

$$
\text { النسمية لنع الوقوع في خطأ. }
$$

9. منع التسمية بالأسماء التي تعتمد على النطق وليس الكتابة (عبالسميع، عبالرحيم،

$$
\text { عبالرحمن،...). }
$$

(§) بر امج التتقيق الإملائى تعتمد على المسافة باعتبار ها الفاصل الطبيعى في تصحيح الأخطاء

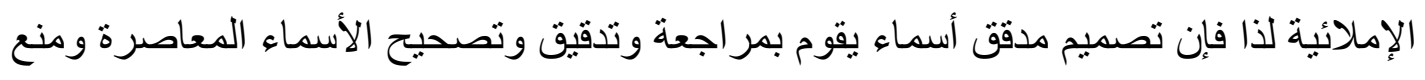

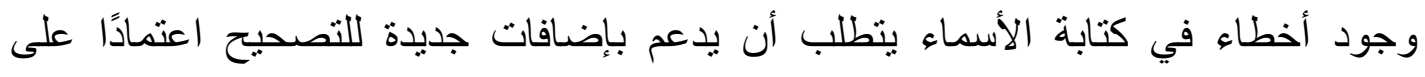
معلومات:

$$
\text { r. أ. أطو ال الأسماء ومركبات الأسماء وشيوع الاسم. }
$$

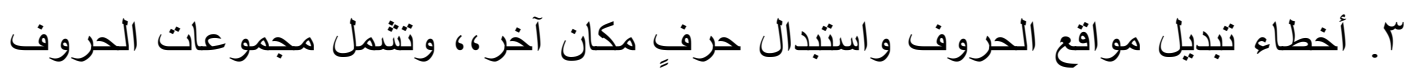

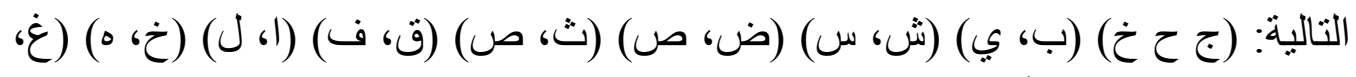

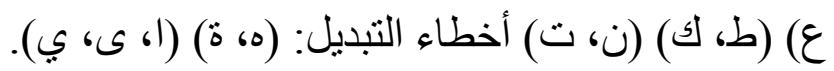

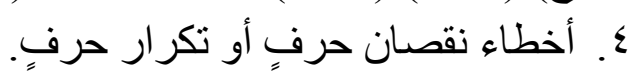

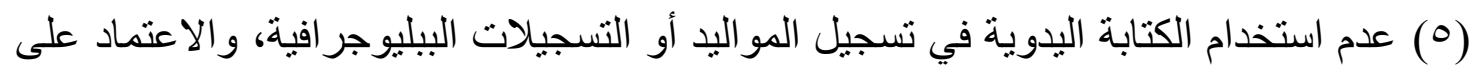

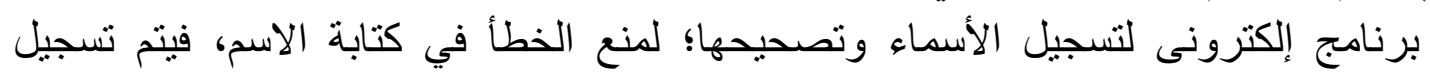


الأسماء بشكلٍ إلكترونى، و لا يتم تأكيد التسجيل إلا بعد مر اجعة الاسم من خلال مدقق الأسماء

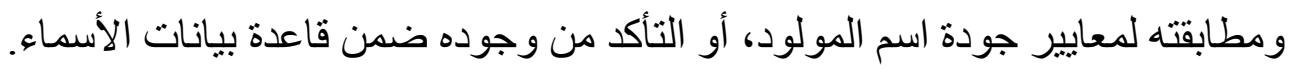

(7) من أجل إتاحة الحرية للمواطنين في اختيار الاسم الذى يرغبه لطفله، مع منع الحيرة بين كون الاسم ذكرًا أو أنثى، يتم إضافة رمز مميز للتفرفة بين الذكور والإناث، مع استخدام

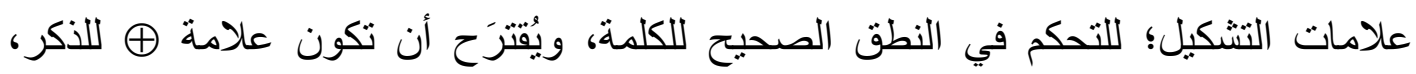
و علامة ه للأنتى، ويتم إضافتها بعد الاسم الأول مباشرة على النحو التالى: إسلام إسلام

( اختلفت طرق الكتابة بين التاء المربوطة و الهاء (صبحه، صبحة)، وبين الألف و الياء (سها،

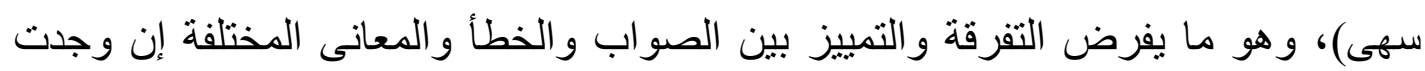

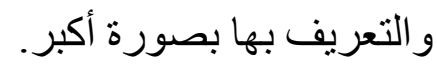

(^) نُعد مشكلات الهمزة والألف و الباء و الهاء و التاء المربوطة و المسافة و النقطة، أكثر مشكلات

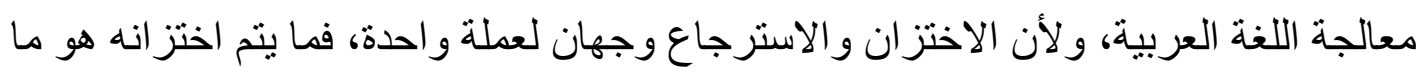

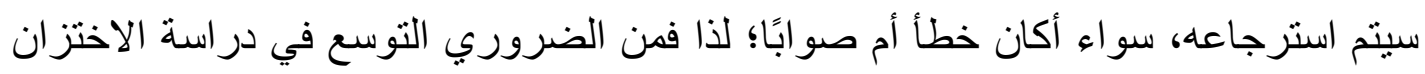
و الاسترجاع ومشناكلهما فى در اسات مستقبلية.

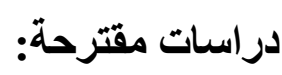

ينتهى البحث إلى اقتر اح دراسة أشكال وصيخ كتابة أسماء المؤلفين القدامى والمعاصرين،

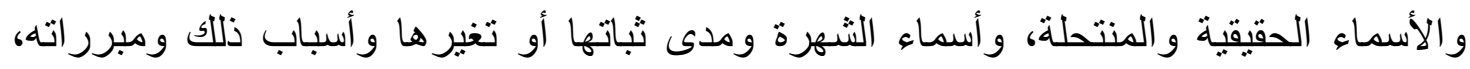

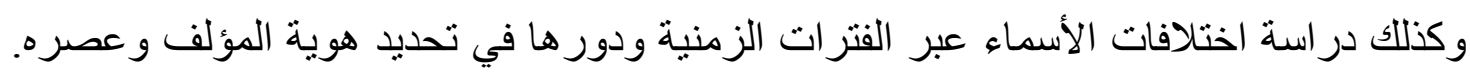

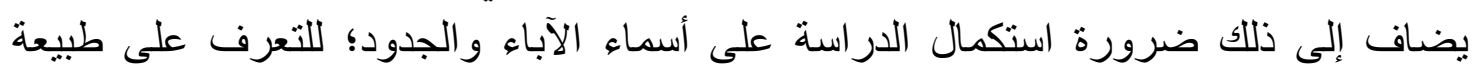
وخصائص أسماء كل فترة، وتطبيقها على باقى المجتمعات العربية للوصول إلى ضبط ومعيارية؛

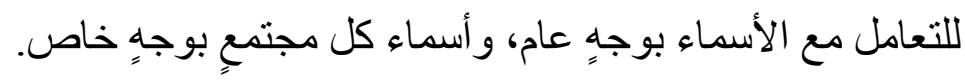




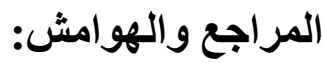

(1) محمد فتحى عبد الهادى. ركائز الضبط الببليوجر افي العربي: نظرة عامة ودعوة للتقنين والتوحيد.-

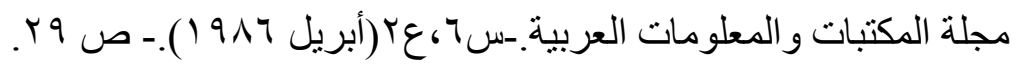

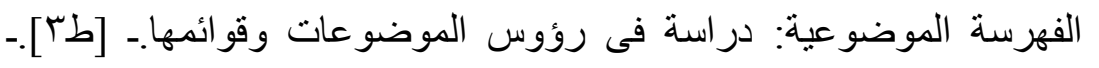

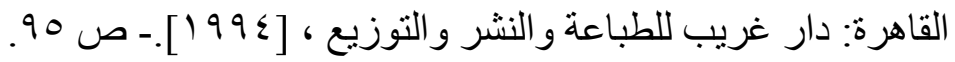

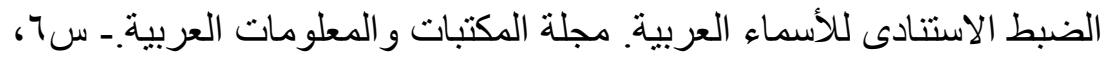

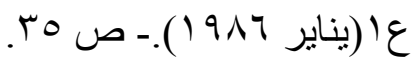

المدخل إلى علم الفهرسة.- القاهرة: دار غريب للطباعة والنشر والتوزيع

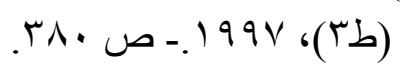

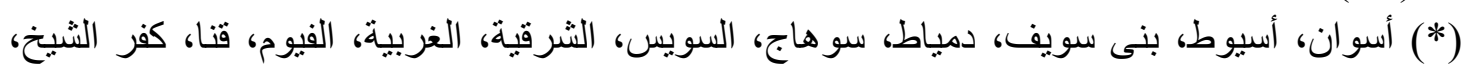

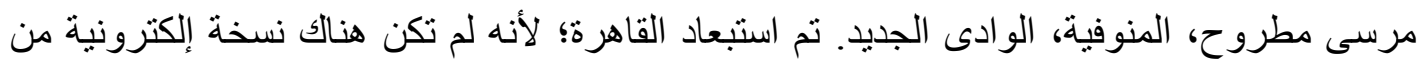

(0) حشمت قاسم. تحليل الاستشهادات المرجعية وتطور القياسات الور اقية. فى كتابه: دراسات فى علم

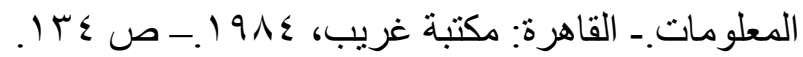

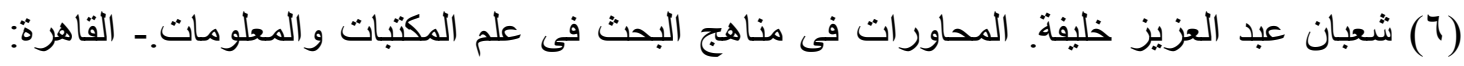

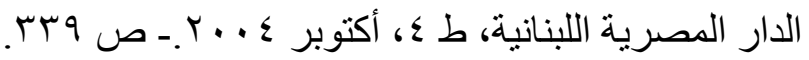

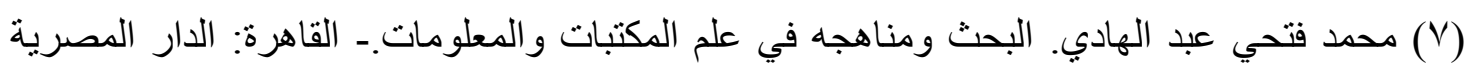

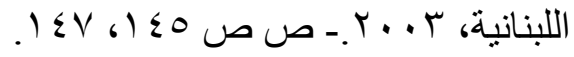

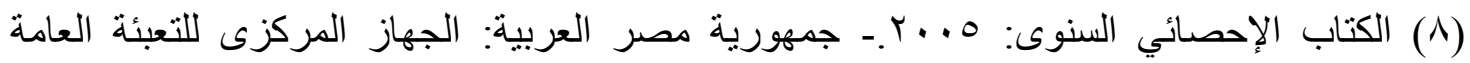

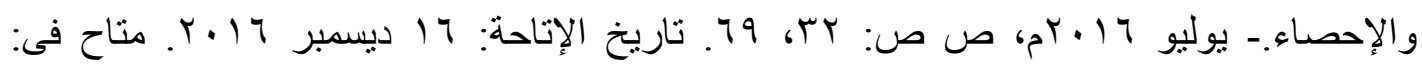

.http://www.t-series.capmas.gov.eg/pdf/book_year/year_book_r...0.pdf (9) فوزي خليل الخطيب. مداخل أسماء الأشخاص فى فهارس المكتبات العربية.- مجلة المكتبات

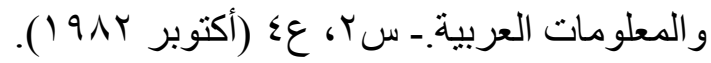

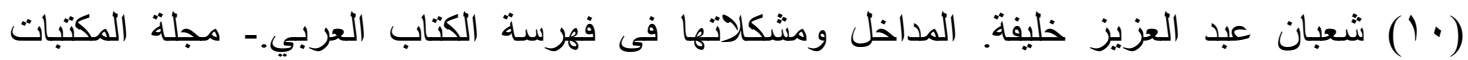

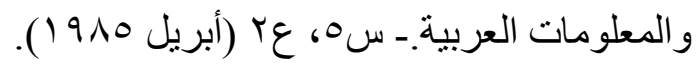
(11) (1) محمد فتحى عبد الهادى. الضبط الاستنادى للأسماء العربية. مرجع سابق.

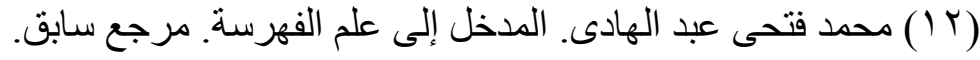

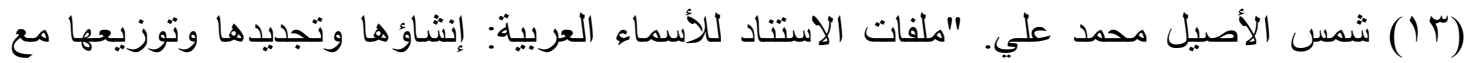

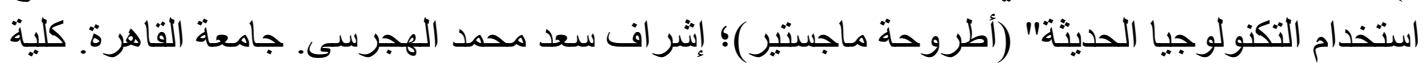

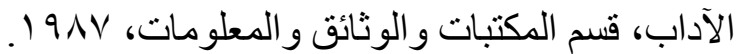

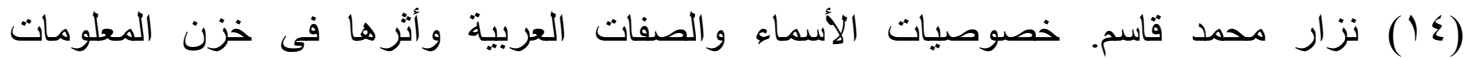

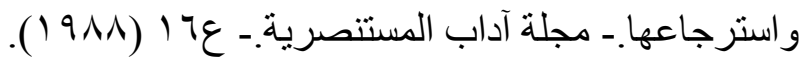


(0) سامية حسن الساعاتي. أسماء المصريين: الأصول والدلالات والتغير الإجتماعي.- القاهرة: الهيئة

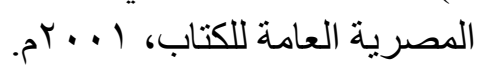

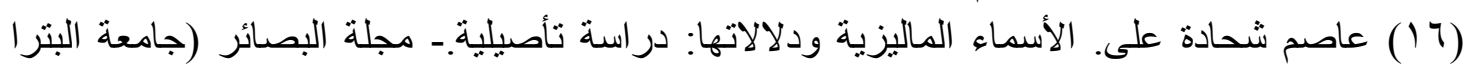

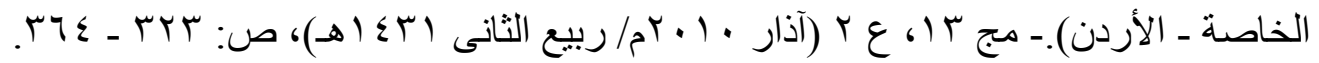

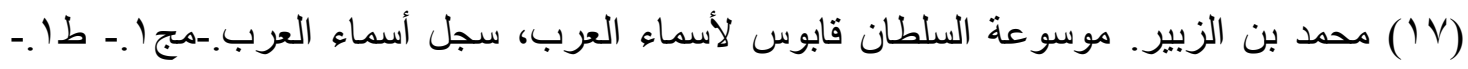

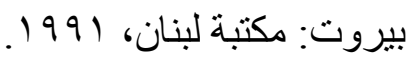

(1) (1) أبو أوس إبر اهيم الثمسان. أسماء الناس في المملكة العربية السعودية.- طا. .- الرياض: مكتبة

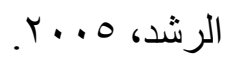

(9 (1) بكرى محمد الحاج. الأسماء العربية ذوات الظلال الدينية: دراسة إحصائية لغوية.-- الخرطوم:

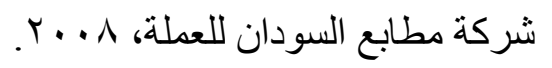

(20) M.M.M. Snyman, M. Jansen van Rensburg, (2000) "NACO versus ISAN: prospects for name authority control", The Electronic Library, Vol. 18 Issue: 1, pp.63-68, https://doi.org/10.1108/02640470010320470.

(21) John L. Cotton, Bonnie S. O'Neill, Andrea Griffin, (2008) "The "name game": affective and hiring reactions to first names", Journal of Managerial Psychology, Vol. 23 Issue: 1, pp.18-39, https:// doi.org/10.1108/02683940810849648.

(22) James Powell, Linn Collins, Ariane Eberhardt, David Izraelevitz, Jorge Roman, Thomas Dufresne, Mark Scott, Miriam Blake, Gary Grider, (2012) "“At scale" author name matching with Hadoop/MapReduce", Library Hi Tech News, Vol. 29 Issue: 4, pp.6-12, https:// doi.org/10.1108/07419051211249455.

(23) Kamil Wais, (2016) "Gender Prediction Methods Based on First Names with genderizeR", The R Journal, Vol. 8/1, Aug, pp.17-37, https://journal.rproject.org/archive/2016/RJ-2016-002/RJ-2016-002.pdf.

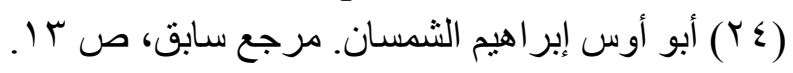

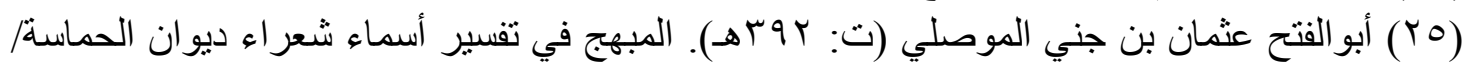

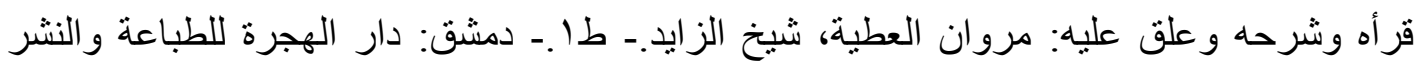

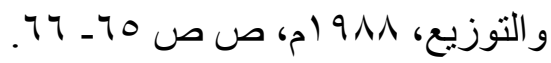

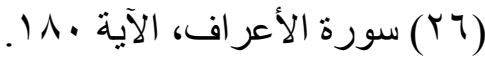

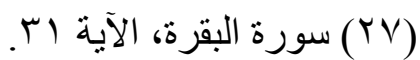

(Y^)

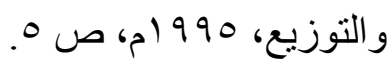


(Y9) محمد سعد. المنهج النبوى فى اختيار الأسماء.- مجلة الوعي الإسلامي - وزارة الأوقاف و الثئون

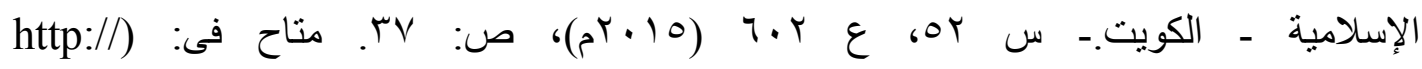
.). (search.mandumah.com/Record/673603

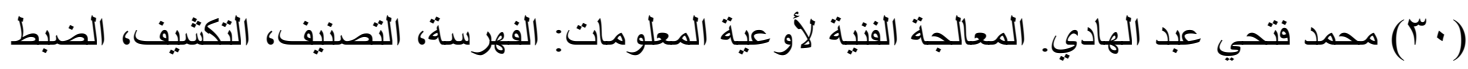

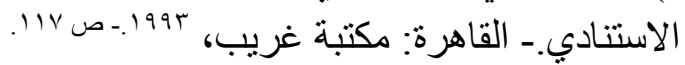

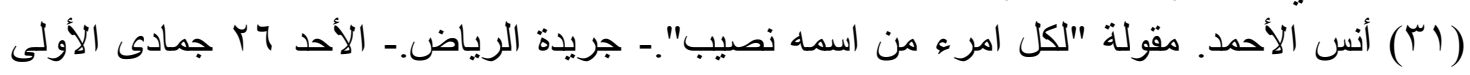

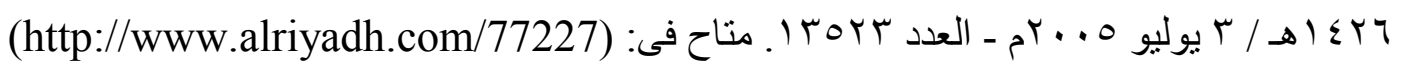

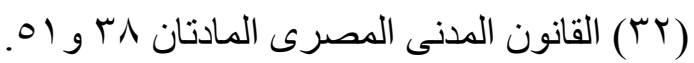

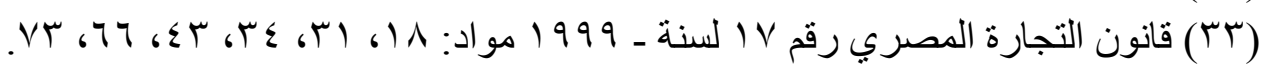

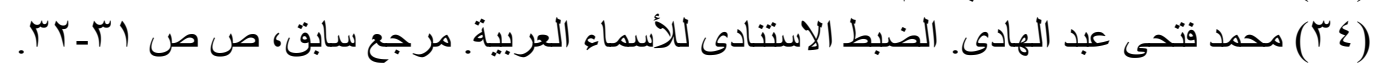

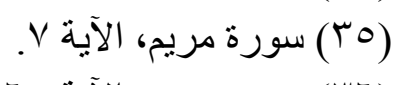

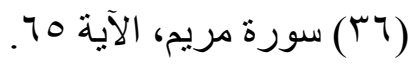

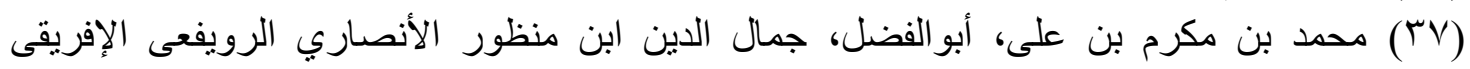

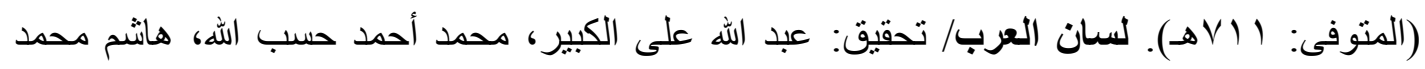
الثـاذلى.- القاهرة: دار المعارف، د.ت.

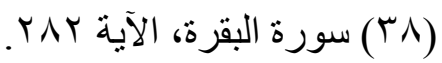

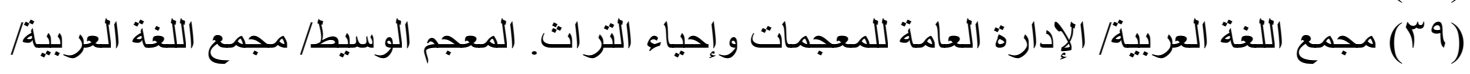

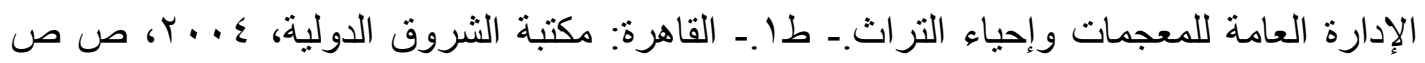

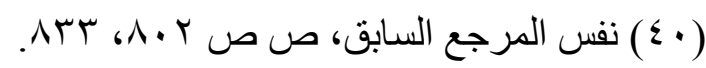

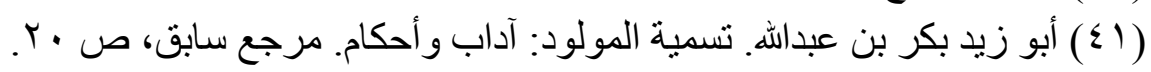

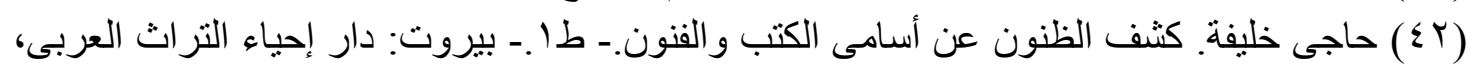

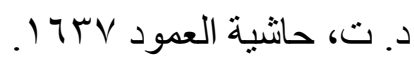
(*) كان سبب تأليفه لكتابه أن هناك من تقوّل علي العرب بأنهم سموا بأسماء بلا معانٍ لها، و هو ما نفاه

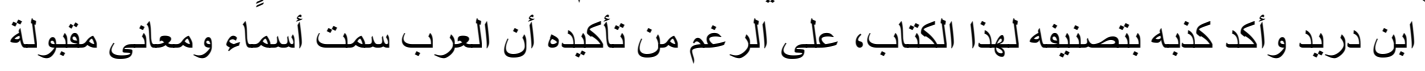

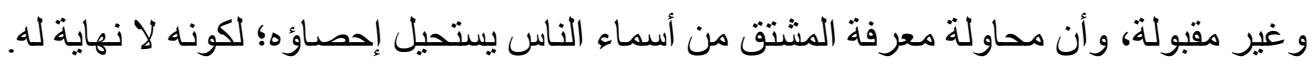

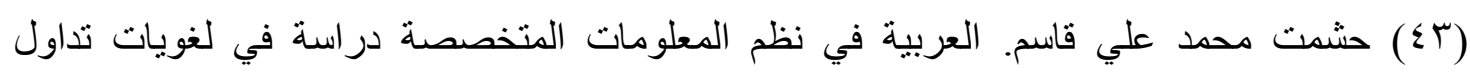

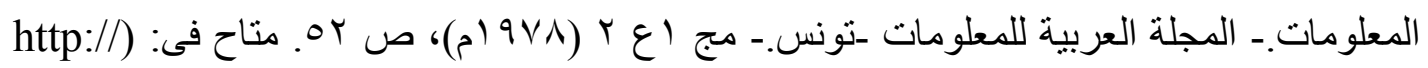

(search.mandumah.com/Record/29317

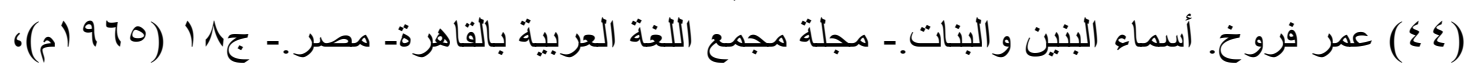

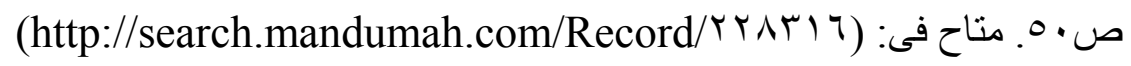

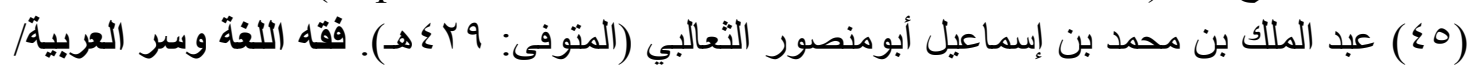

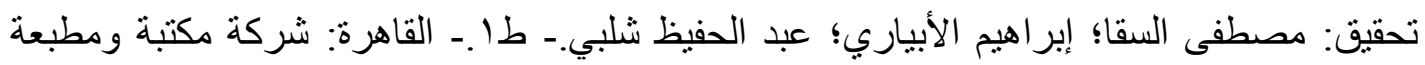

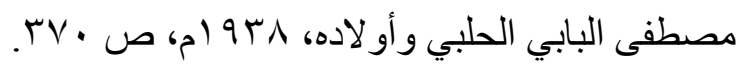




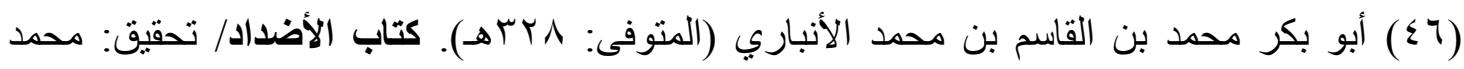

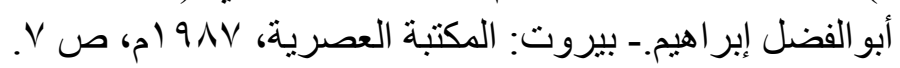

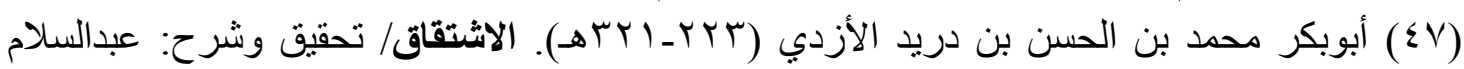

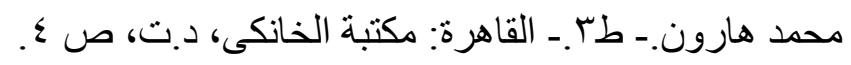

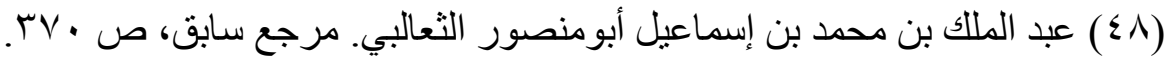

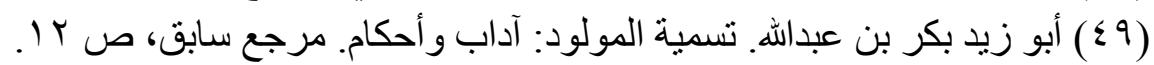

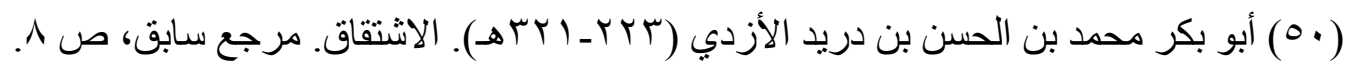

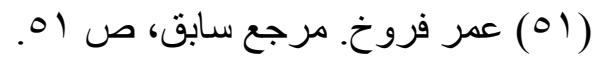

